\title{
أثر تدريب معلمي اللغة العربية للصف الأول الابتدائي في ضوء مدخل التركيز المبائي على الرمز على أدائهم التذريسي لابني
}

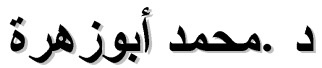 \\ الأستاذ المساعد بشعبة بحوث تطوير المناهج \\ المركز القومي للبحوث التربوية والثنمية
}

مجلة/لدراسات الثربوية والاسانية ـ كلية التربية ـ جامعة دمنهور 
أثر تدريب معلمي اللغة العربية للصف الأول الابتدائي في ضوء مدخل الثركيز المبائي د. محمد أبوزهرة

\section{المجلد الخامس العدد (1) لسنة 2013}


مجلة الدراسات التربوية والاسيانية ـ كلية التربية ـ جامعة دمنهور - المجلد الذامس العدد (1) لسنة 2013 
أثر تدريب معلمي اللغةة العربية للصف الأول الابتدائي في ضوء مدخل التركيز

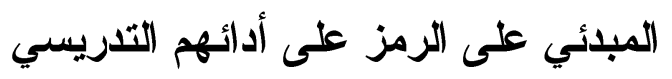

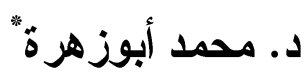

أولاً: مشكلة البحث والخطة العامة لار استها:

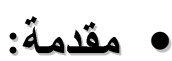

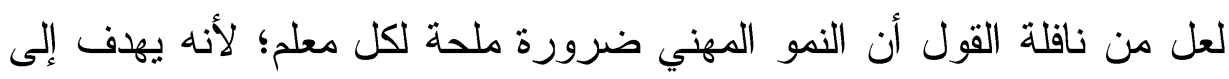

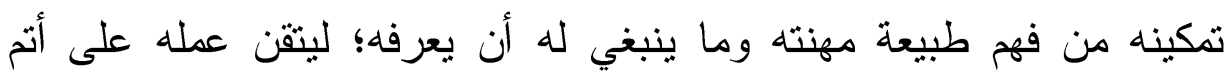

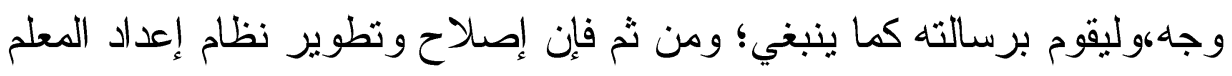

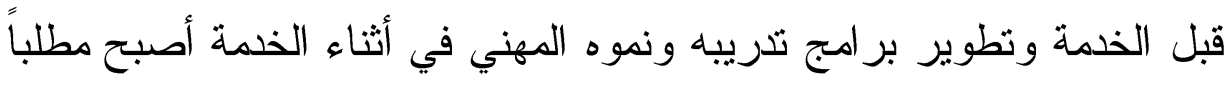

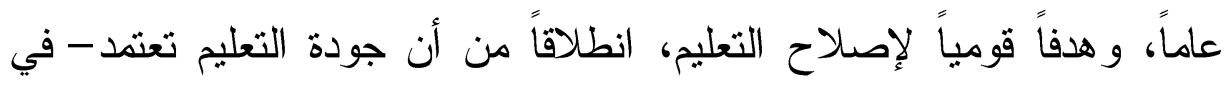
المقام الأول - على جودة المعلمين.

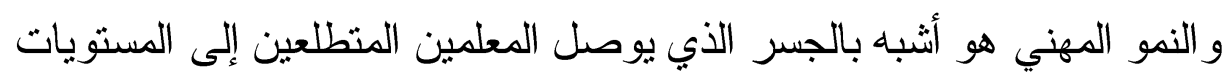

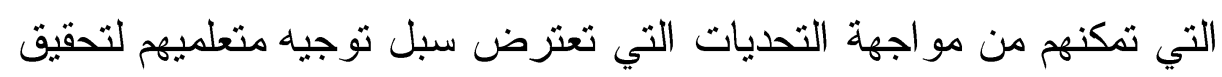

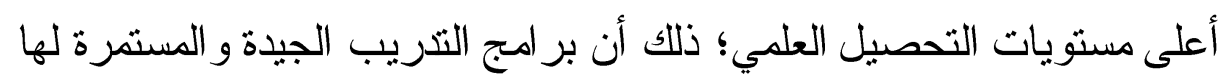

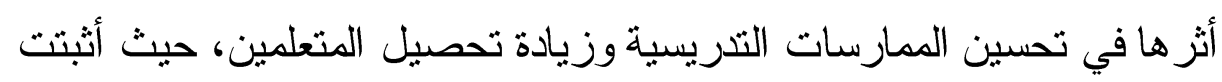

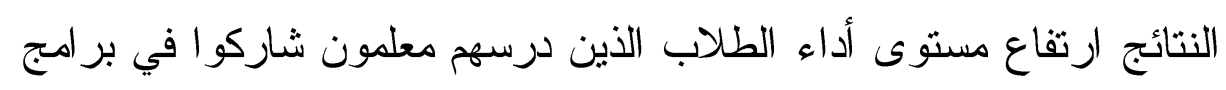
التنمية المهنية المستخيمة (NCSL, 2002,P.1).

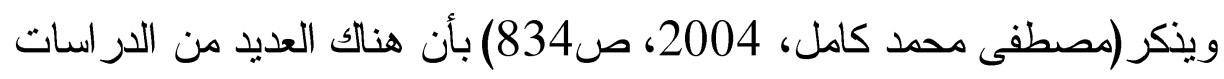

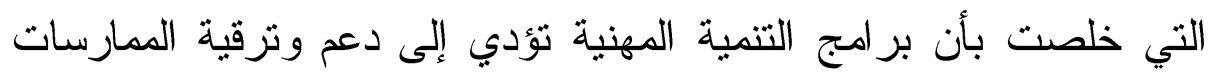

" أستاذ المناهج وطرق تدريس اللغة العربية المساعد - شعبة بحوث تطوير المناهج - المركز القومي للبحوث التربوية و التنمية.

doi : 10.12816/0001054 
التدريسية و المعلومات الأكاديمية للمعلمين وخاصة الجدد، وتوفر لهم فرص الانفتاح على القضايا التزبوية المعاصرة وبر امج تحسين عناصر المنظومة ولاديه التعليمية، مما يمكنهم تطبيقها بكفاءة فينعكس ذللك بدوره على تعلم التلاميذ.

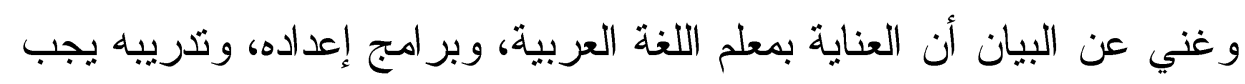

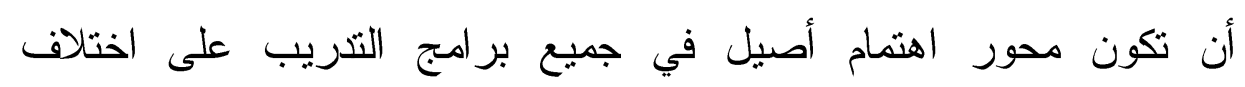

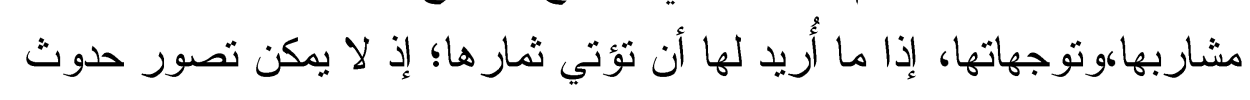
تطوير في غيبة الهوية، وضياع الذات الثقافية ممثلة في اللغة العربية ومعلمها؛ فلغة أية أمة هي هويتها، وو عاء ثقافتها، ومعلم اللغة هو ذلك الكيان الإنساني

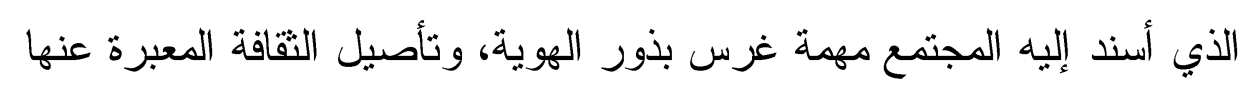

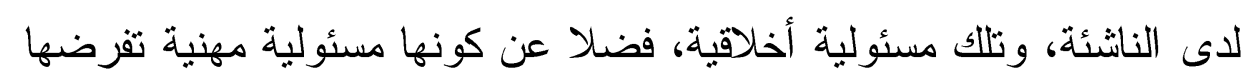

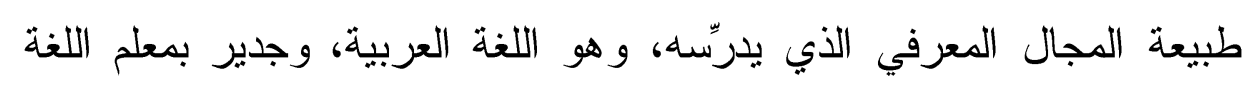

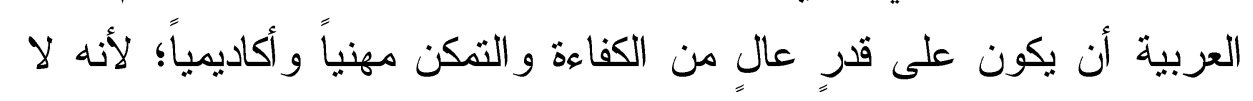

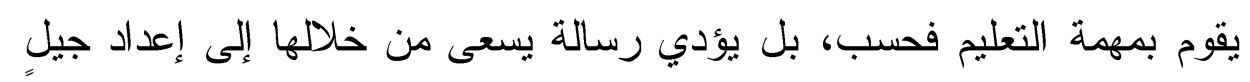
معتزٍ بلغتههومقدساته.

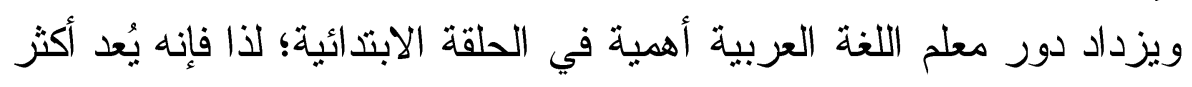

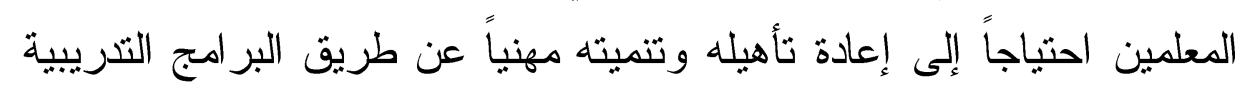

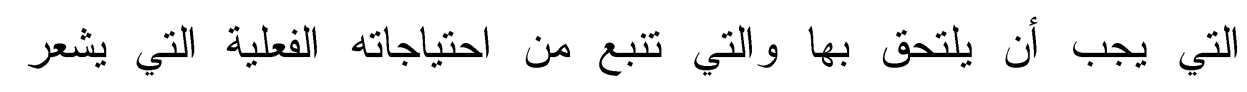
بها،و تفرضها عليه متغير ات ومتطلبات المجال الذي يعمل به في وقتتا الر اهن.

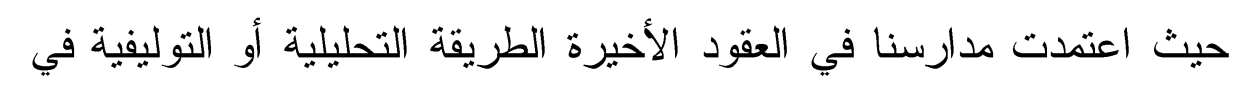
تعليم اللغة العربية، ويبدو أن هذه الطريقة قد أثنتت عجز ها في الإتيان بالنتائج المرجوة منها، حتى نادى علماء اللغة ورجال التربية إلى تغييرها، و الانتقال بالمنهاج الى الطريقة التركيبية؛ الطريقة الجديدة في تعليم اللغة، و التي يوصي الثياء بها المنهاج الموضوع حديثاً للغة العربية 2012/ 2013- كما نشر مؤخر أ- 
وهي الطريقة التركيبية التقليدية؛ البدءهن الحرف و أصو ات الحروف، ومن ثم الكلمات و الجمل. ويبدو أن التغيير في الطريقة لم يكن تغييراً عشو ائياً أو ارتجالياً، بل كان بناء التهاء على اختبار ات وتجارب، فقد كانت الخطوة الأولى أن وزارة التربية و التعلـيـيم

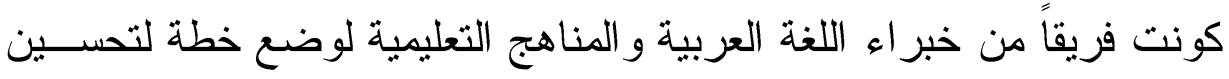
القر اعة في الصفوف الثثلاثة الابتدائية، حيث قام فريق العمل باستعر اض العديد

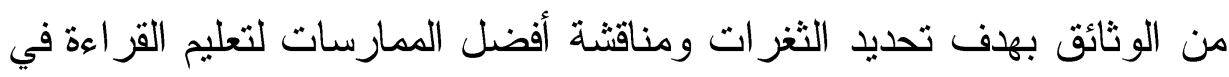

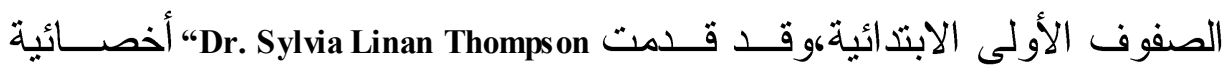

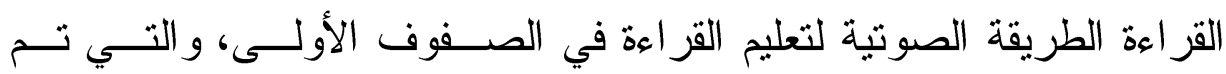

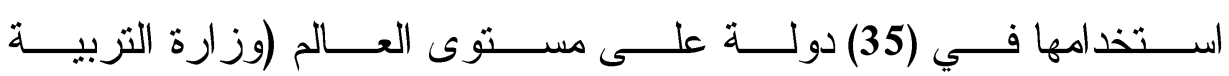

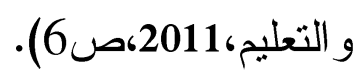
و الو اقع أن العقود القليلة الأخيرة قد شهدت تغييرات جذرية في طر ائق تعليم القر اعة في العالم، وذللك على خلفية ما توصلت إليه البحوث العلمية الأخيرة التي أظهرت أن تطور القر اعة في المر احل الأولى (Shankwiler \& Fowler, 2004)

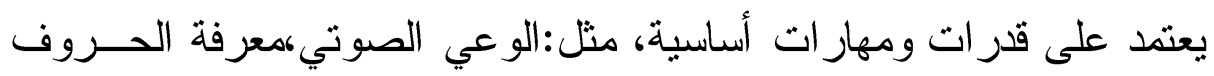
التركيب الصوتي و التعرّت الدقيق و السريع على الكلمات (سناء طيبي، 2006)

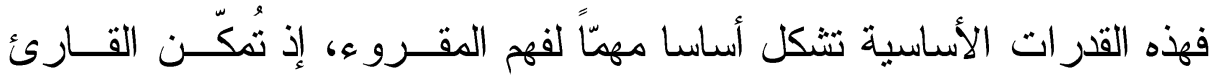
المبتدئ من تحويل القدرة على فلكّ الرموز إلى قدرة أوتوماتيكية، وهو ما يُتيح

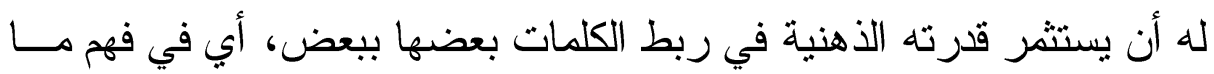

ولعل أهم النتائج التربوية لهذا التحول هو التغيير في طر ائق تعليم القراءة،وذلك

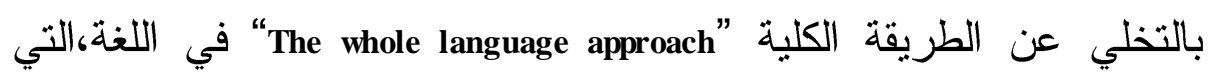
توصي بتعليم اللغة كوحدة واحدة، وبناءً على ذلك، استُبلت الطريقة الكلية doi : 10.12816/0001054 
بالطريقة الجزئية ”Phonics" التي تولي تعليم المهارات الأساسية في القراعة

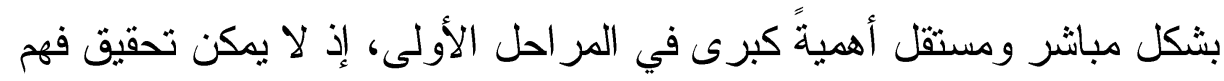

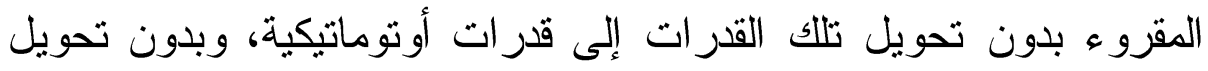

المعرفة اللغوية إلى مهارة من خلال التمرين و الممارسة (Ehri et al., 2001).

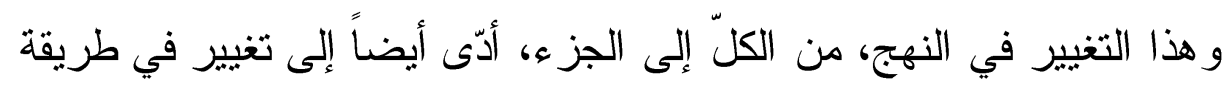

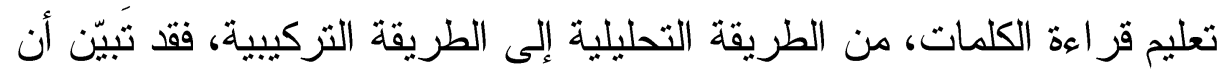

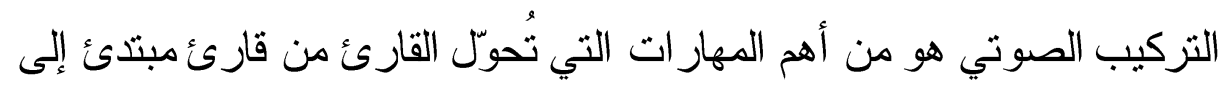
قارئ متمرس (Share, 1995).

وبناء على ما تقدم نستخلص "أن نقطة البدء في تعليم القراءة يجب أن تكون

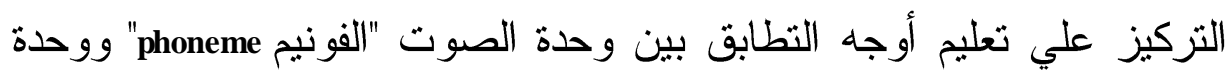

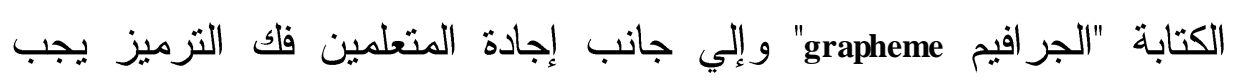

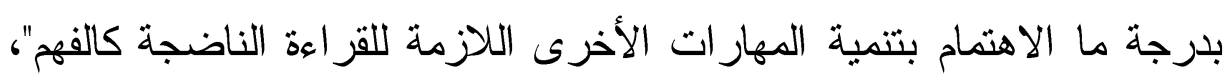
و هذا ما نعني به "مدخل التزكيز المبئي على الرمز"، أو المدخل الصوتي.

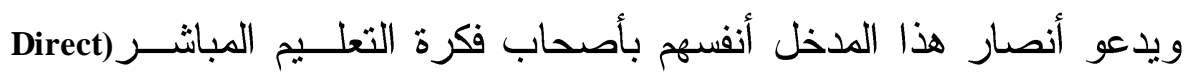
(instruction

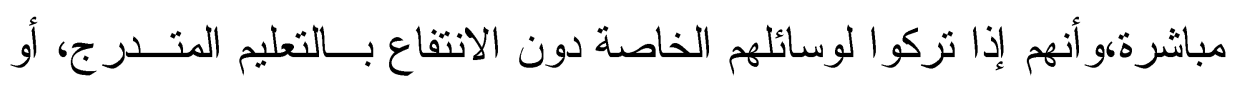

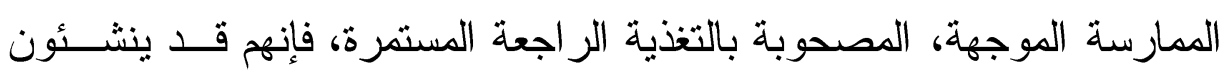

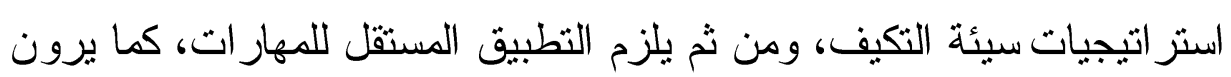

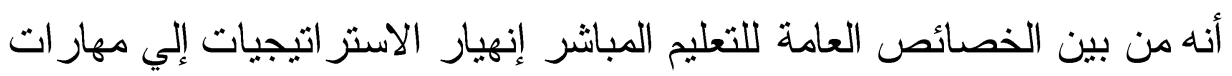

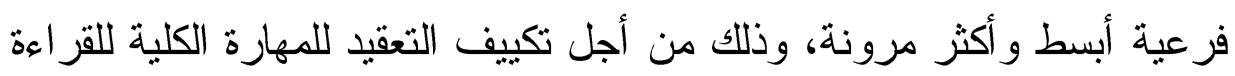
.(Pearson \& Garcia, 1991, p. 43) وأشارت "آدز" Adams (1990) كذلك إلي أن "القر اء المهرة يحللون مصفوفات

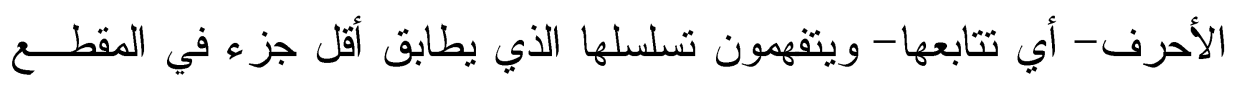


اللغوي، وطبقا لنتائج البحث المعملي فإن هذا التسلسل يشكل إنماء الهجاء التي يدركها القر اء المفحوصون (Shankweiler, 1991 , p. 34) ويقام أنصار هذا المدخل العديد من المسوغات و المبررات التي تدعم فعالية تسلسل تعليم القزاءة من الجزء إلي الكل، بوصفها مهارة مركبة ومعقدة لا لانيل

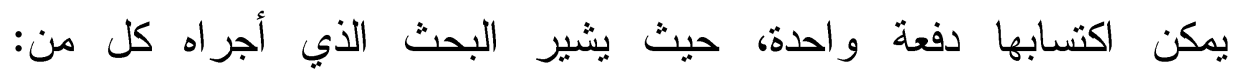
بarchbanks \& Levin الحضانة و الصف الأول الابتدائي - في التحقق من اللفظ إلي أن الثكل الكلي لإني للكلمة كان أقل الأدلة المستخدمة، وكانت الأحرف الأولي أكثر الأدلة استخداما،

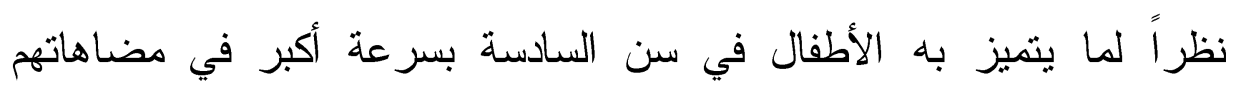

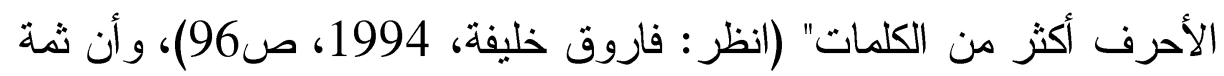
دليل على أن التزكيز على الرمز من البداية يحسن القدرة على فلك الرموز خاصة في الصف الأول و الثاني الابتدائي (Wyse, 2000).

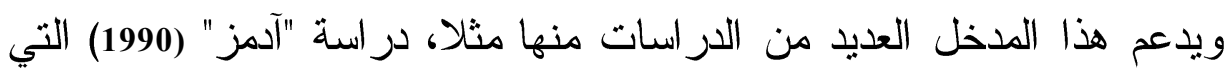
استهدفت فحص آلاف الدراسات و اعتمدت في نتائجها علي مصادر متتوعة

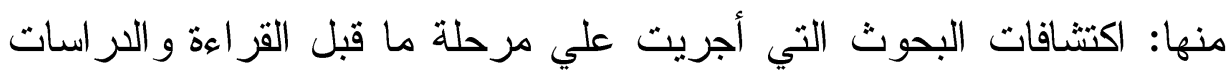

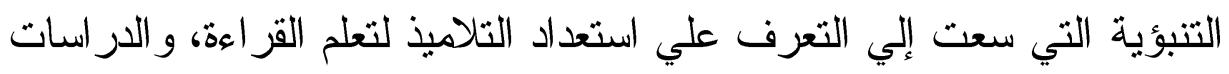
التتبعية للنتائج التزبوية طويلة الأجل الخاصة بالاخفاق في فلك الترميز في التئي الصفوف الاولية، و الدراسات المتصلة بالتعرف علي الخصائص المشتركة بين

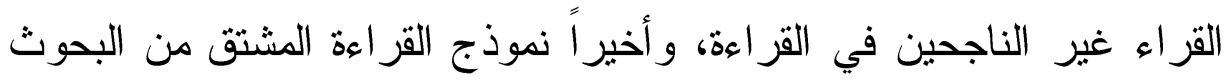

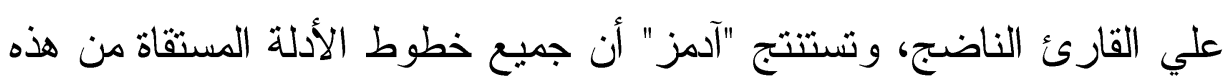
المصادر تتآذر للتأكيد علي الأهية الحيوية لمساعدة الأطفال علي فهم مبدأ الألفباء منذ بداية تعليمهم (Barr, 1991, pp. 30-35). 
وقد أثنار "Minskoff" إلى أن التشريب على التزميز الحرفي يمكن أن يحسن

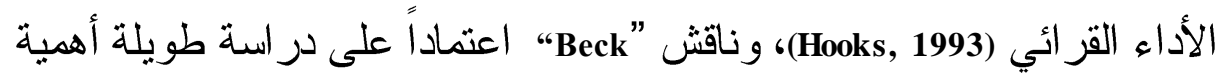

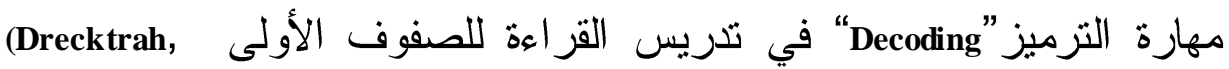
1997) ويعد الوعي الصوتي بإدر الك و استيعاب الطفل أن الكلمات المنطوقة عبارة عن

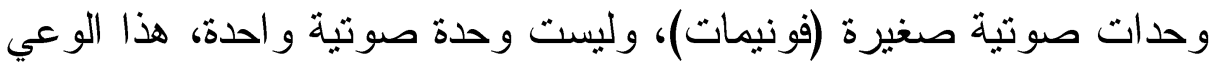

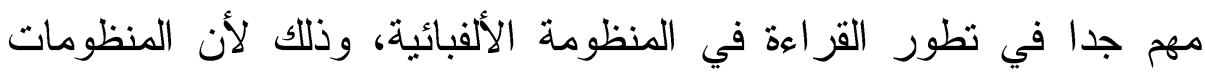

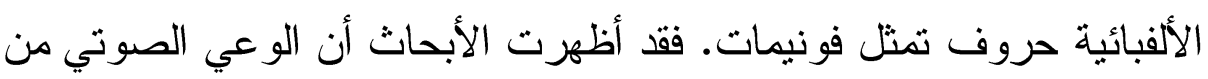
أهم المنبئات بقرة الطفل على قر اءة الكلمات وفهم المقروء Panel, 2000) وفي مجال صعوبات تعلم القر اعة درس هوكس (hooks, 1993) أثر وهرة الطريقة الصوتية في تعليم الطلبة ذوي صعوبات التعلم، و أظهرت النتائج زيادة في مهار ات القراعة وتذكر الكلمات، ووجد أدوارد (Edwards, 2000) أن الناحية الصوتية كانت الأكثر تتبؤاً بالقدر ات القر ائية. وفي مجال المقارنة بين مدخل التركيز على الرمز وغيره من المداخل توصل

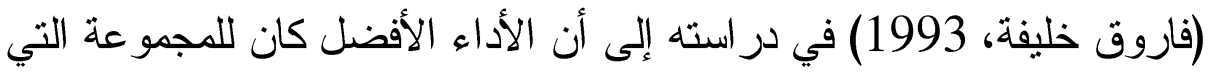

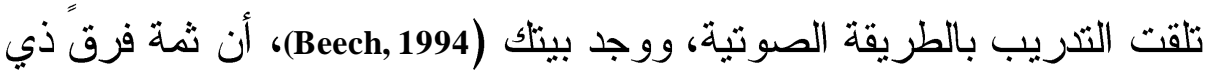
دلالة لصالح المجمو عة التي تلقت التّريب الصوتي، وكذلك سمث (smith, 1998) الذي درس فاعلية الطريقة الكلية و الصوتية في تدريس القر اعة، وأثنار ات نتائج الاختبار البعدي إلى وجود فرق ذي دلالة لصالح المجمو عة التي تلقت التشريس

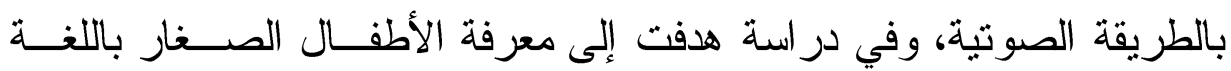

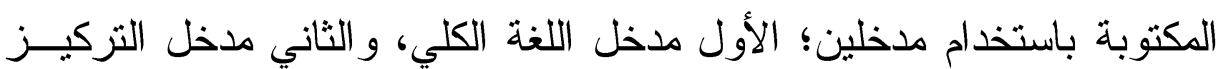

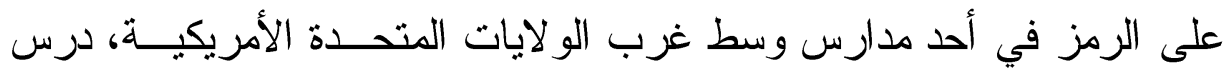
بالمدخل الأول (34) تلميذا، وبالمدخل الثاني (30) تلميذا، وقد طلب من كـــل طفل على حده كتابة قصة حياتية لغيره من القر اء مــرة فـــي بدايــة العــام

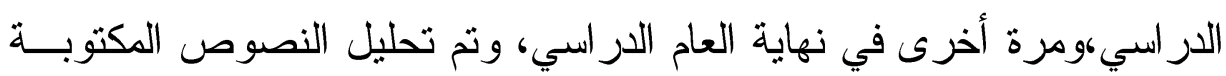
309 
لغويا و إحصائيا في ضو ء ثلاثة سمات أساسية، و هي:الاستقلالية ومر اعاة تقاليد

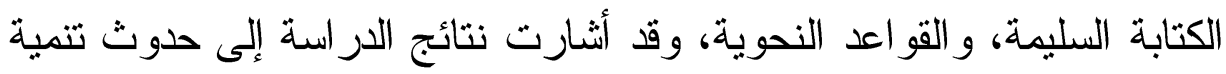

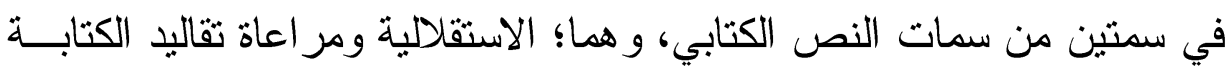

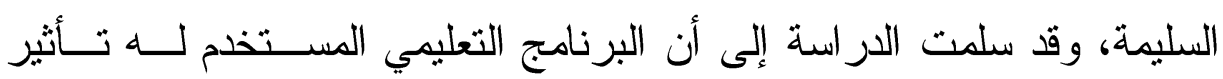
ضعيف على تتمية فهم التلاميذ للغة المكتوبة (Fang, Z., 2010).

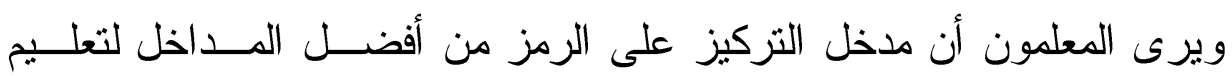

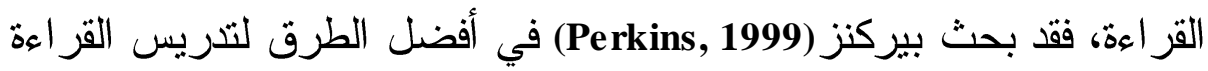
و الكتابة للتلاميذ الأفارقة الأمريكان في الددارس الإبتدائية في ولاية تكساس، شارك في هذه الدراسة (21) معلماً، قام الباحث بمقابلتهم وتسجيل هذه المقابلات الإندان

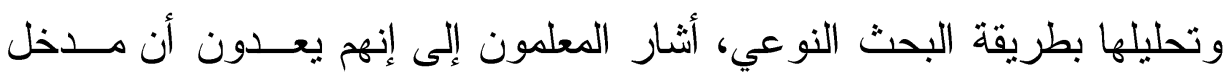
التركيز على الرمز أفضل الوسائل التي يستخدمونها في تعليم القراءة لهؤلاء

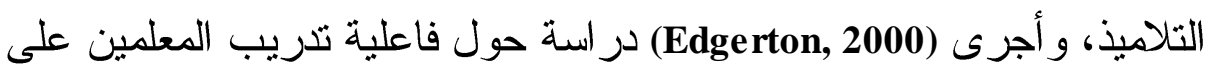
المدخل الصوتي، شارك فيه عشرة من المدرسين، حيث تلقو اتدريباً لمدة ثانية

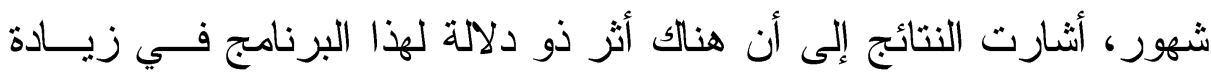

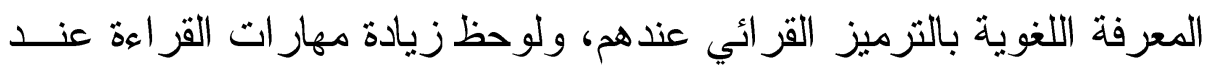

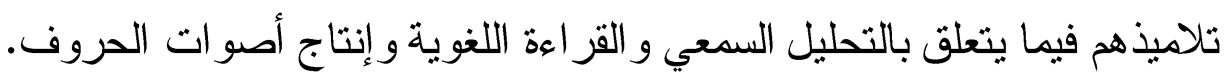

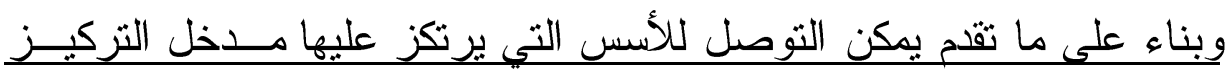
المبئي على الرمز، وذللك على النحو التالي: • تعليم الحروف الأبجدية فى بداية القراعة بوصفها المثير الأول الذى يؤدى التئي

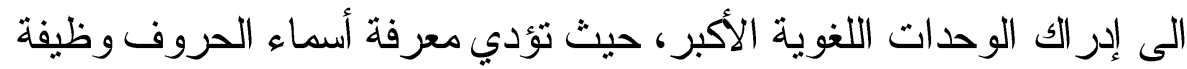
مهمة في تطور القراعة لدى الأطفال (Levin et al., 2005) ، فضلاً عن أن أن

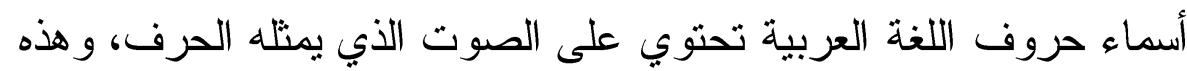
الميزة في أسماء حروف اللغة العربية يمكن أن تسهم في زيادة وعي الأطفال doi : 10.12816/0001054 
(Levin, لأصوات الحروف، وبالتالي اكتسابها كمهارة أساسية في القراعة

Saiegh-Haddad, Hende \& Ziv, 2008)

• التدرج فى عملية تعليم القراءة حيث قدمت الأحرف بأصو اتها وبالحركات الثناث الفتحة، و الكسرة، و الضمة، فمعرفة الأطفال للفونيمات (الأصوات)

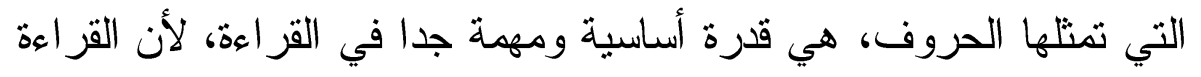
في المراحل الأولى تعتمد - في الأساس - على تحويل الحروف فه إلى إلى الأصو ات التي تمثلها (Treiman \& Rodriguez, 1999) • التدرج فى تقديم الكلمات؛ حيث يقدم كلمات مكونة من ثلاثة أحرف - في البداية- ثم زيادتها تدريجيا، ثم تقديم كلمات بحروف منفصلة مشكولة بحركة

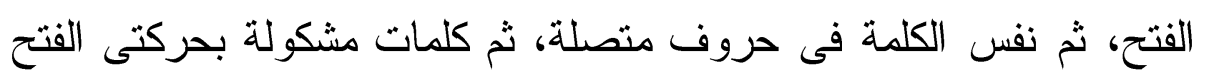
و الكسر، ثم كلمات مشكولة بالحركات الثلاث.

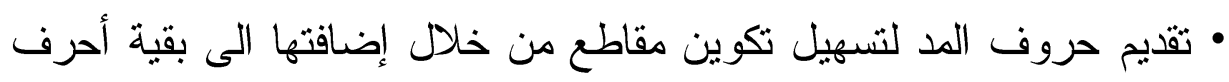
الكلمة.

6- التّرج فى المطابقة بين الحروف والأصوات حيث قدمت كلمات يكون فيها التطابق تاما، ثم الانتقال الى كلمات يكون التطابق فيها غير تام، و هذا يحقق التتابع الزمنى و المكانى بين ما ينطق وما يكتب ويؤدى الى سرعة

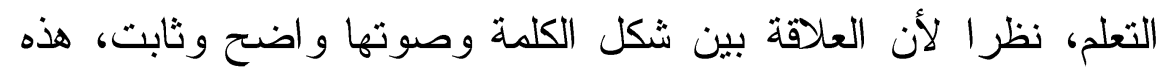

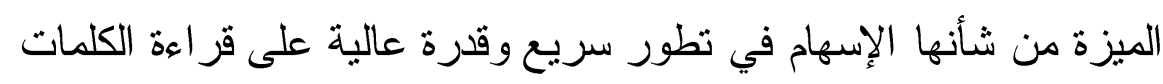

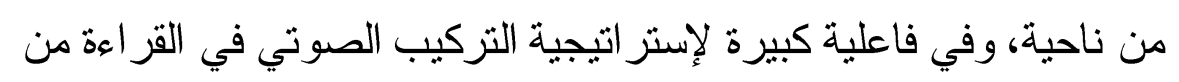
ناحية أخرى (Elbeheiri \& Everatt, 2007)

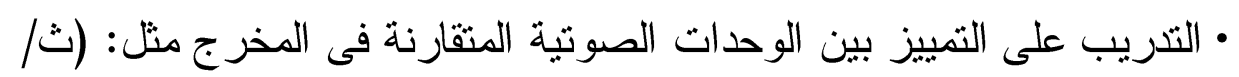

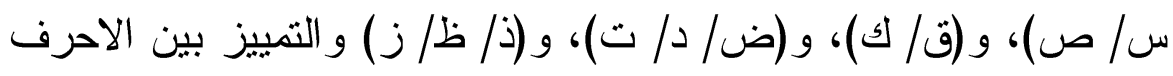

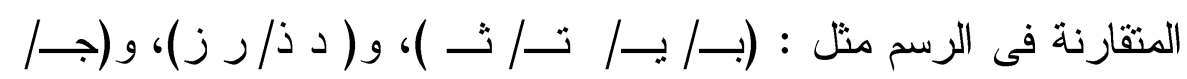

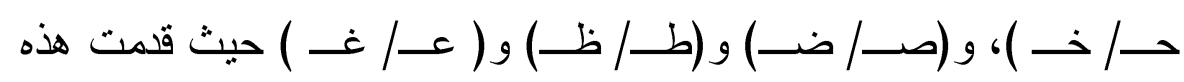
الحروف فى فترة متقارنة حتى يرسخ التمييز بينها فى أذهان التلاميذا. 311 
• الاهتمام بإدر الك القيم الخلافية للأصوات و أثز ها فى تشكيل المعنى؛ بتقديم تدريبات تعرف الكلمة من خلال بنيتها وشكلها العام.

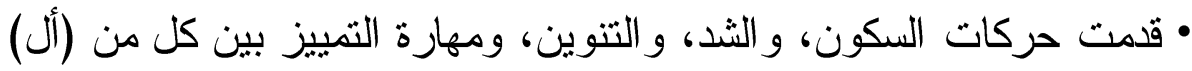

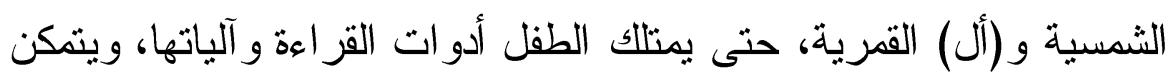
من التثريب عليها فى الدروس التالية.

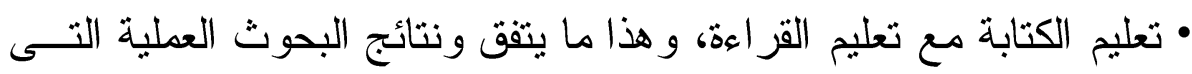

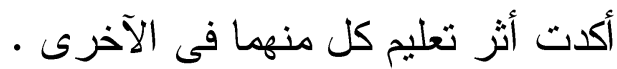
• السير وفق خطة متكرجة وفقا لنطور لغة الاطفال فى المفردات و التز اكيب و أساليب التعبير، حيث تقدم الكلمات المألوفة التى تدل على ولى معانى محسوسة كما قدمت اولا الجمل البسيطة ثم الجمل الأكثر تعقيداً .

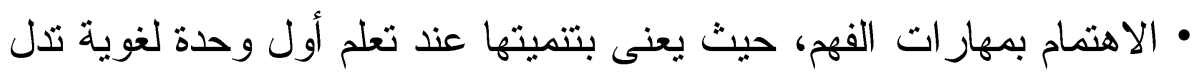
على معنى -وهى الكلمة - وذلك من خلال التدريبات المتنو عة، و ألا تؤكد

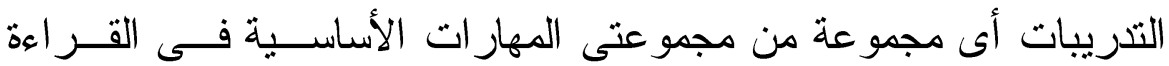
(التعرف و الفهر) على حساب المجمو عة الأخرى. • الاهتمام بمهار ات؛ الاستماع، و التحدث ضمن تدريباته، كما يعني بتنميــة

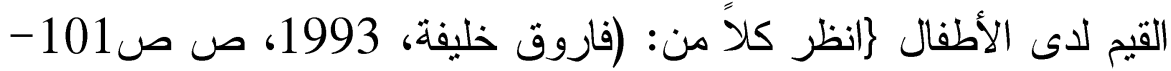

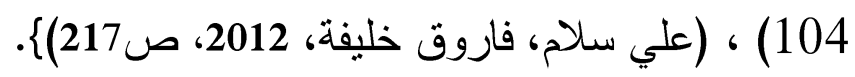

\section{• الإحساس بالمشكية:}

قامت وزارة التربية والتعليم بالتعاون مع مشروع تحسين الأداء التعليمي للبنات

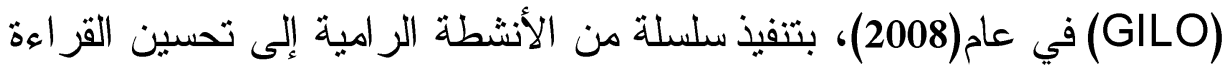
بين تلاميذ الددارس في أربع محافظات(بني سويف، الفيوم، المنيا، قنا)،وقد أجرت وزارة التربية والتعليم بالتعاون مع المشروع في عام (2011) تقييماً لمهار ات القراعة في الصفوف الأولى حول تأثير المدخلات التي نم تنفيذها من doi : 10.12816/0001054 
(2008)، وبينت النتائج تفوق التلاميذ في المدارس المشاركة في البرنامج على ألى التلاميذ المدارس غير المشاركة، وذللك في ثلاثة معايير هي: قراءة المقاطع

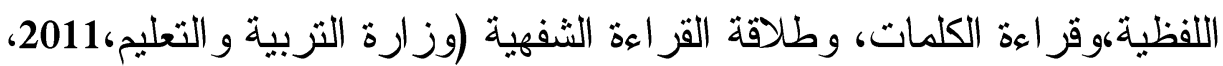

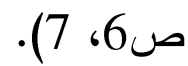

وفي أكتوبر (2011) قررت وز ارة التزبية و التعليم أن يكون استخدام طريقة تعليم القر اءة إلز امياً لكافة معلمي ومعلمات الصف الأول الابتدائي، حيث أعلنت أنه "يجب أن يتعلم كل طفل مصري القر اعة و الكتابة بالطريقة الصوتية، كما ينبغي على كل معلم ومعلمة للصف الأول أن يتعلم طريقة تعليم القراعة و الكتابة للصف الأول الابتدائي بهذه الطريقة".

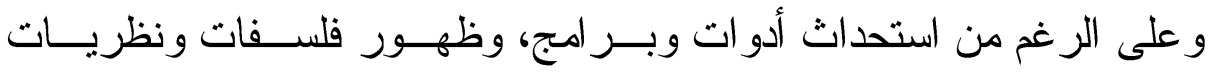
و اتجاهات في مجال التربية، فإن جودة التعليم وكفاءته لا يمكن أن تتحقق إلا

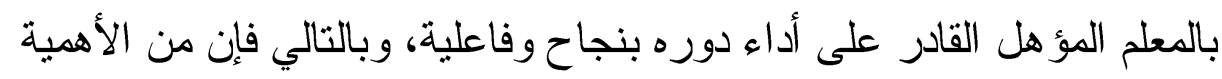
بمكان إجر اء عملية إعادة توجيه جذرية لإعداد وتدريب المعلمين تكفل تزويدهم

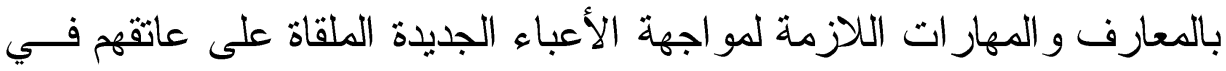
ضو ء ما طر أ من تغيير في طريقة التعليم، و هو ما تسعى إليه الدراسة الحالية.

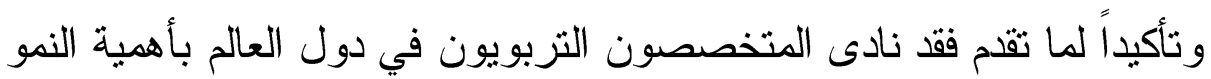

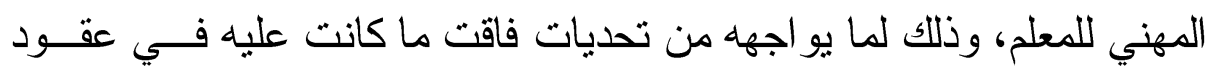

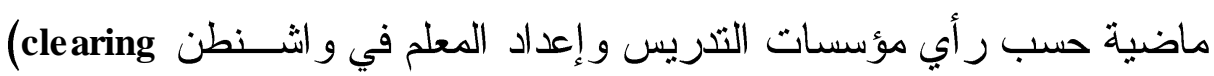
(Corcoran, 1995,p. 1) والتطوير المهني استجابة (house, 1995, p. 1)

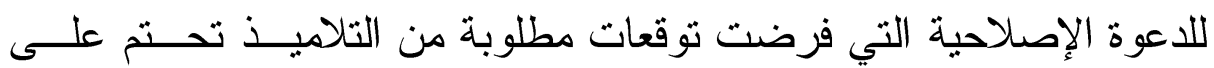

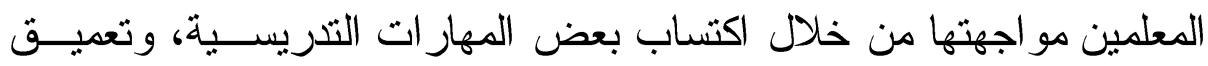
معارفهم وتعلم طرق و أساليب جديدة للنتريس. ويرى كل من (Dilworth\& Imig, 1995, p. 1) أن تربية المعلم و النمو المهني هما من أهم أهداف التربية و التعليم، وأن المعلمين المعدين و المتكربين بشكل 
جيد هم مفتاح النقلة الددرسية حيث تقع على عاتقهم الجهود الإصلاحية، وأن الارتباط بأي شكل من أثكال التطوير المهني يضمن استمر ار تجديد التنريس، بحيث يظل مثتعا طالما يستمر المعلمون في تعلم وتضمين أساليب وتقنتيات جديدة (Correia\& Mchenry, 2002, p. 68). وفي ضوء ذلك يجب أن تطور برامج ندريب المعلم المهارات المعرفية

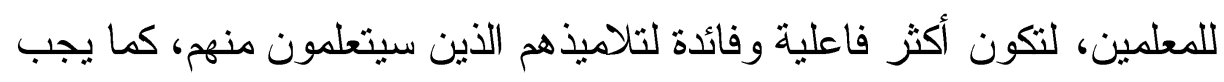

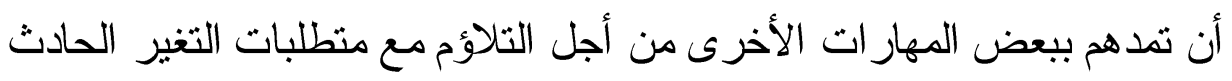

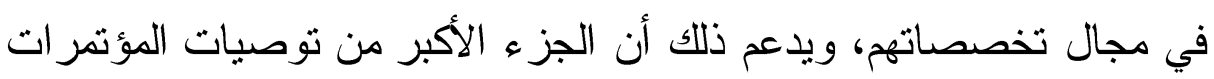

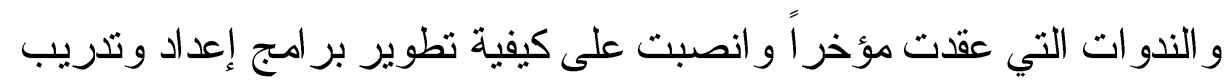

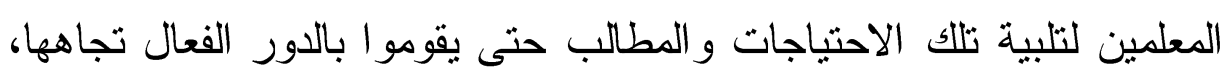

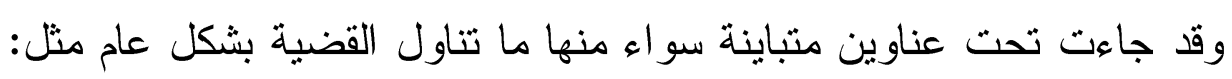
إعداد المعلم - التر كمات و التحديات (1990)، إعداد معلم التعليم العام (1990)،

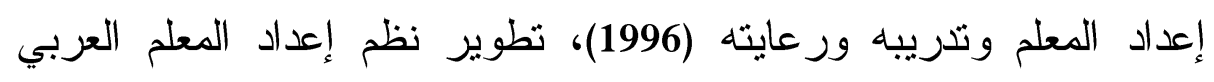

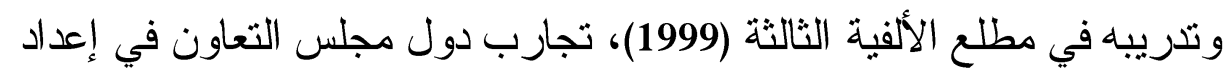

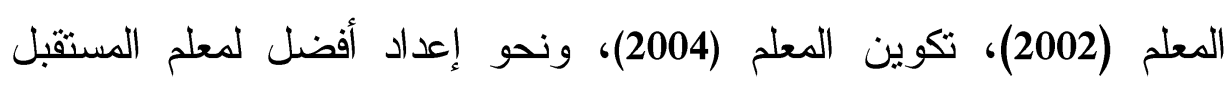

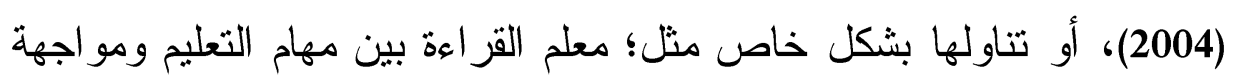

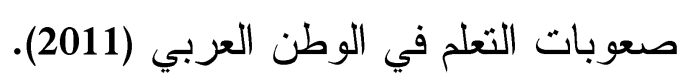

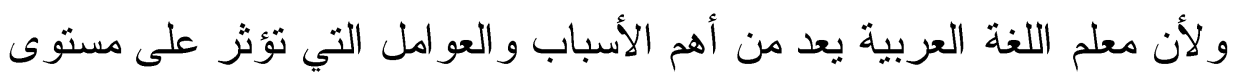

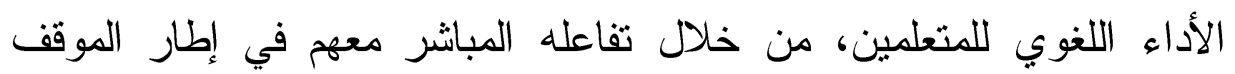

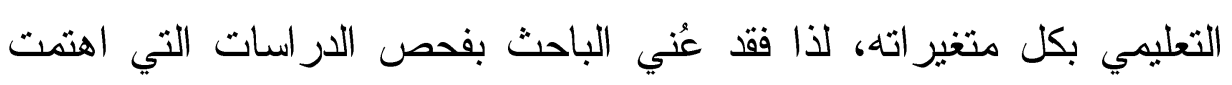

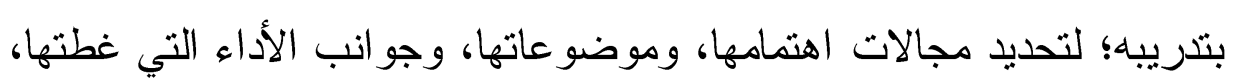
وتحديد موقف الدراسة الحالية منها. 
ومن هذه الدراسات التي اهتمت بتدريب معلم اللغة العربية في الوطن العربي من خلال اقتر اح برامج لتتمية مهار ات معينة لديه، دراسة (محمود حمود الموسى،1987) التي عنيت بتطوير الكفاءات التذريسية لمعلم اللغة

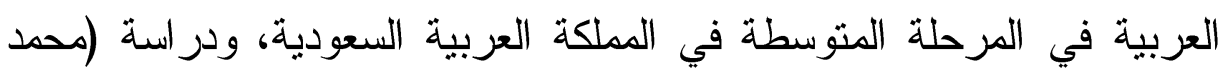
ابر اهيم الخطيب الخطيب، 1990) التي عنيت بتتمية الكفايات التعليمية المتدنية لاى طلاب اللغة العربية بالكليات الأردنية، ودراسة (مباركة صالح الأكرف،

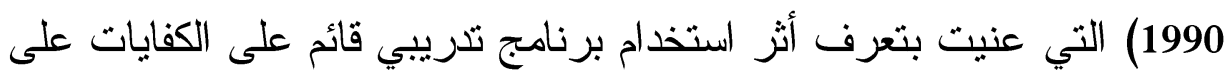

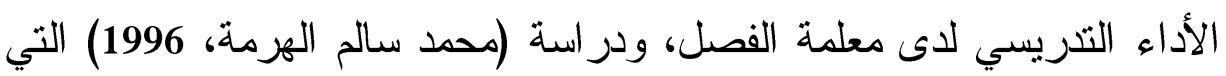
عنيت بتنمية بعض الكفايات اللازمة لمعلمي اللغة العربية بالمرحلة الثانوية بليبيا، ودراسة (عبد الرحمن الصغير، 1996) التي عنيت بتتمية الكفايات المهنية اللازمة لمعلم اللغة العربية للناطقين بلغات أخرى في أثناء الخمة، لبنه

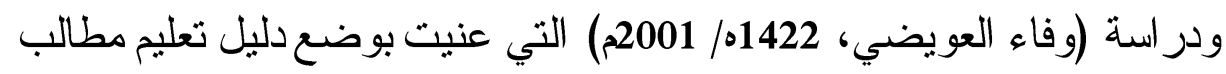
مقرر طرق تدريس اللغة العربية بكليات التربية للبنات، ثم تصميم برنامج تدريبي قائم على تلك المطالب، وتدريب الطالبات المعلمات على أدائها،

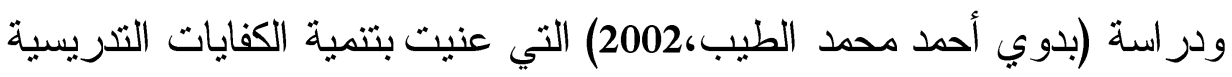
اللازمة لمعلمي اللغة العربية في المرحلة الابتدائية عن بعد، ودراسة (إيمان هريدي،2003) التي عنيت بتدريب معلمي اللغة العربية للناطقين بغيرها من بعن ودئ الأطفال في مصر في ضوء الكفايات اللازمة لهم، ودراسة (محمد رفعت

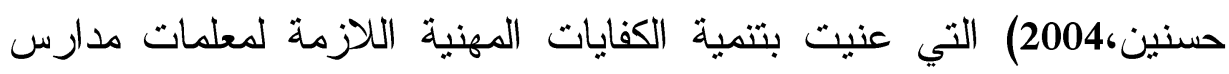
الفصل الواحد في ضوء حاجتهن التدريبية لترريس اللغة العريية، ودراسة (محد السيد سعيد،2005) التي عنيت بتنمية مهار ات تدريس الهجاء لدى فئ الطلاب المعلمين بإستخدام التدريس المصغر، ودراسة (مريم محمد عايد، 2005) التي عنيت بتتمية مهارات التقكير الناقد والإبداعي لمعلمات اللغة ولنة العربية، ودر اسة (عبد الحميد زهري سعد عطا الله 2006) التي عنيت بتنمية 
كفاءات التذريس وتحقيق منطلبات الجودة لدى معلمي اللغة العربية المرحلة الإعدادية، ودر اسة (محمد لطفي جاد، 2007) التي عنيت بتدريب معلمي اللغة العربية بالحلقة الأولي من التعليم الأساسي بسلطنة عمان في ضوء الهي احتياجاتهم

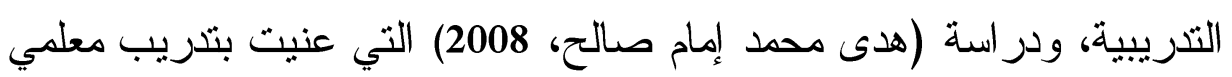

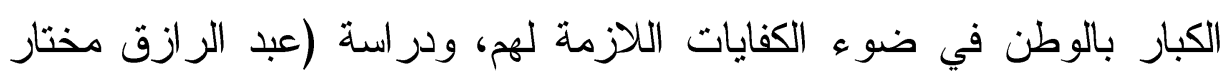
محمود،2008)التي عنيت بتنمية مهارات استخدام معلمي اللغة العربية لاستراتيجيات ما ور اء المعرفة و أثزه علي تتمية الطلاقة اللغوية و التحصيل

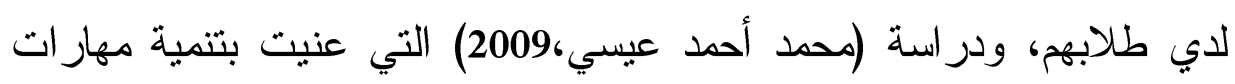
تدريس البلاغة لدى الطلاب معلمي اللغة العربية بكلية التزبية، ودر اسة (بدوي أحمد الطيب، 2010)التي عنيت بتنمية بعض المهار ات اللغوية اللازمة للمعلمين

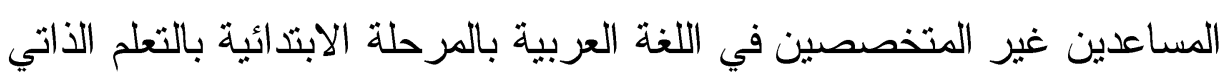
في ضو ء احتياجاتهم. ويتضح من خلال العرض السابق للار اسات التي اتخذت من تدريب معلمي اللغة العربية موضوعاً لها أن كل دراسة ركزت على العابف أحد عناصر أداء معلم

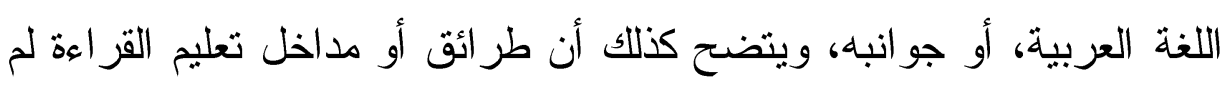

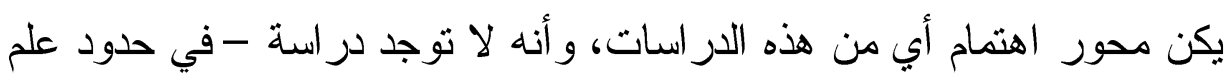
الباحث - حاولت أن تتطرق لموضو ع تدريب المعلمين على مداخل تعليم اللغة لهن

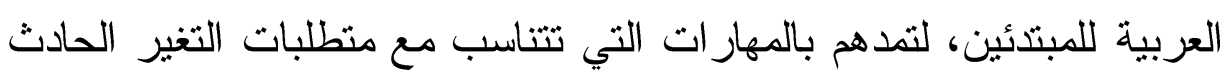

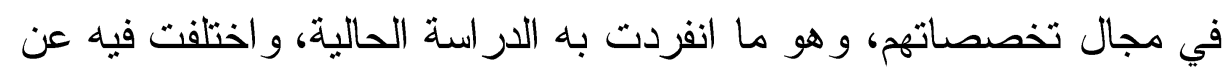
الار اسات السابقة. ولعل هذا ما تُعده كثير من الأدبيات و الدراسات من أوجه القصور التي تؤخذ

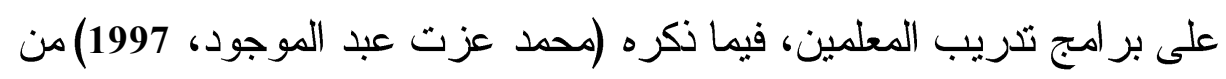
أن بر امج إعداد المعلم وتدريبه، ينبغي أن تتحول من النظريات و الأسس العملية doi : 10.12816/0001054 


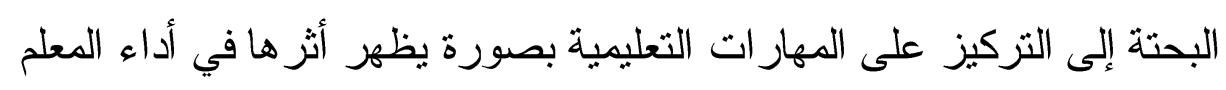
و عمله المهني، إلا أنه يلاحظ على بر امج إعداد المعلمين وتدريبهم - في غالبية

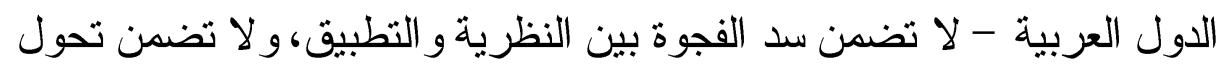
المعلومات و النظريات التربويةو النفسية إلى مهار ات أدائية فعلية.

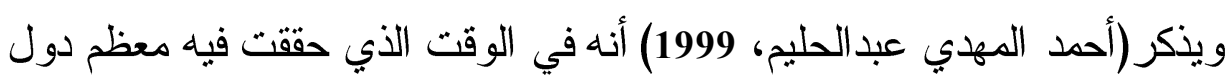

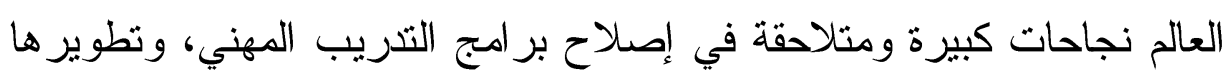

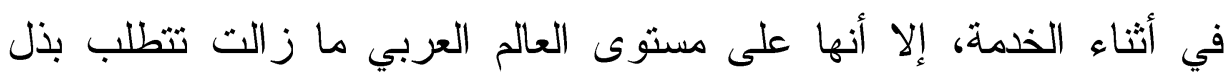
المزيد من الجهود في هذا الثأن.

ويشير (محمد رجب فضل الله، 1998) في مجال تدريب معلمي اللغة العربية على وجه الخصوص - - إلى أن برامج تدريب معلمي اللغة العربية أثناء الخدمة تقليدية ومتو اضعة في مستو اها، و لا بر اعى في تصميمها وتنفيذها

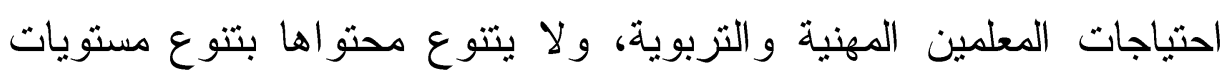
المعلمين، و المر احل التعليمية التي يعملون فيها.

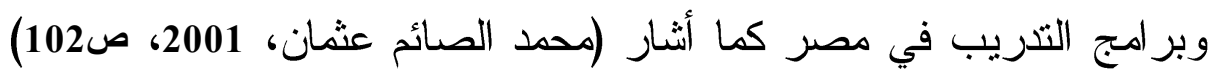
تخضع للنظام المركزي، و أن مر اكز التدريب التابعة للإدارة العامة لا تشترك

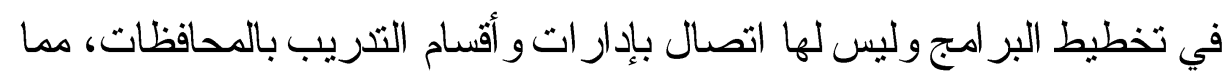

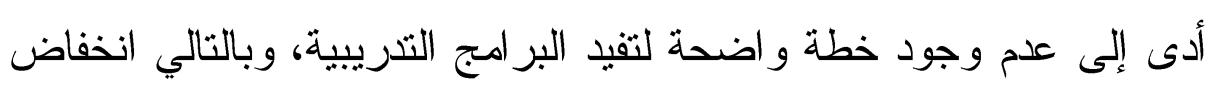
المستوى التّريبي للمعلمين أثناء الخدمة. وقد كان لهذا القصور انعكاساته السلبية على أداء معلمي المبندئين، الذي وصفهـ الذئه

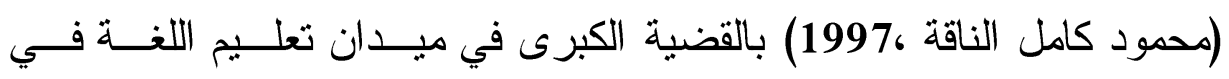
الصفوف الأولى، و التي تكمن في ضعف - لا بل عجز - معظم معلمي اللغة عن التتويع في استر اتيجيات التدريس، وما يصاحب كلّ استر اتيجية من أسئلة

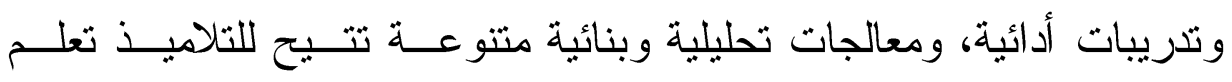
المؤشرات السلوكية للمهارة بشكل منظم وفاعل. 
وتوصلت در اسة للباحث عن وجود انخفاض كبير في مستوى أداء معلمي اللغة

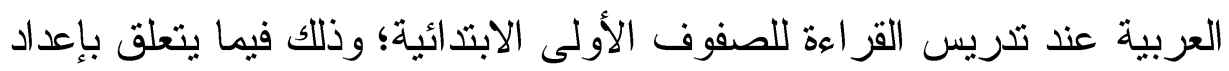
الدروس(42.31\%)،وتثفيذها بنسبة (42.77\%)، وأوصت بعقد دور ات تدريبية -

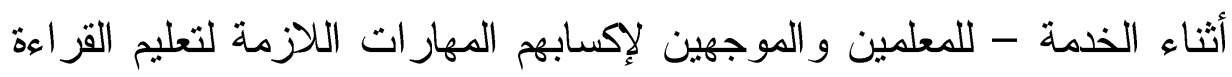

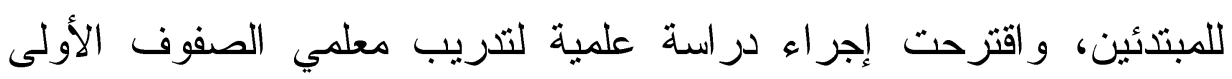

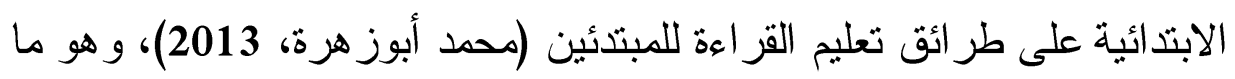
يعد بمثابة النو اة للار اسة الحالية.

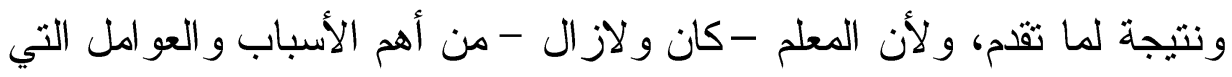

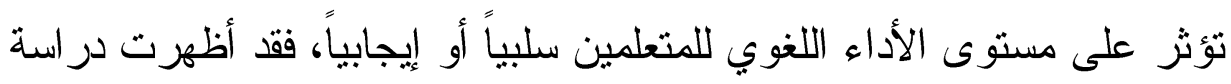

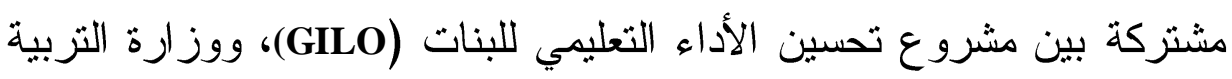

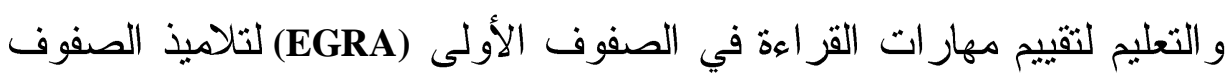

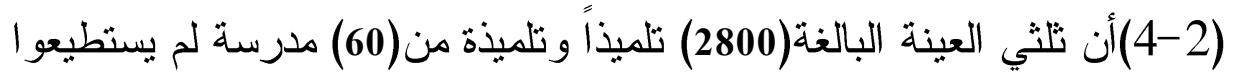
قر اعة كلمة و احدة في فقرة نصية بسيطة.

\section{•مشكلة الادر اسية:}

وتأسيسا على ما تقام يتضح أن واقع تعليم اللغة العربية للمبتئين يشير إلى

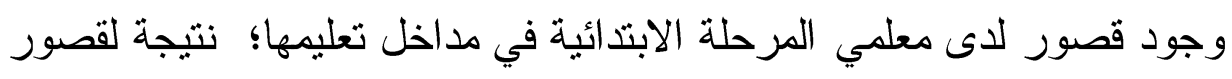
في الإعداد والتذريب، و لابد لهذا القصور التعليمي أن يكون لله انعكاساته

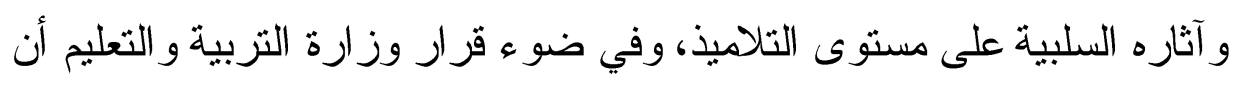
يكون استخدام الطريقة الصوتية إلزامياً لكافة معلمي ومعلمات الصف فئ الأول الابتدائي، بدت الحاجة - ماسة - إلى وضع تصور لبرنامج لنتريب معلمي التئي

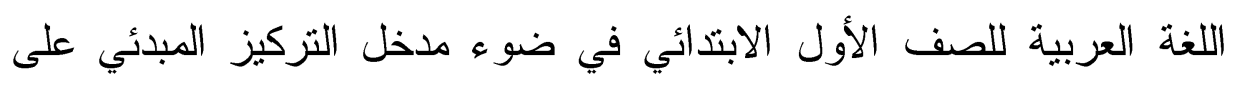
الرمز ، وقياس أثز هذا البرنامج نظرياً وتطبيقياً. 
ويمكن تحديد هذه المشكلة في "ضعف أداء معلمي الحلقة الابتدائية في تعليم اللغة العربية للمبتدئين، مما يتطلب تتميته من خلال تدريبهم في ضو هو مدخل التركيز المبدئي على الرمز". ولعلاج هذه المشكلة ينبغي الإجابة عن السؤالين التاليين: 1- ما أثز البرنامج التريبي المقترح على معارف معلمي الصف الأول الابتدائي حول مدخل التركيز المبدئي على الرمز؟

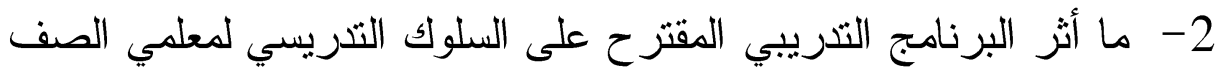
الأول الابتدائي في تعليم اللغة العربية؟

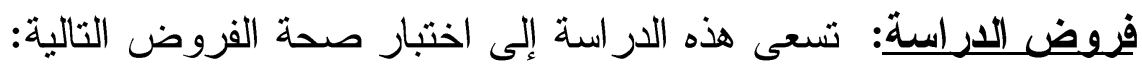
1- "يوجد فرق دال احصائياً عند(0.05) بين متوسطي تلاميذ المجموعتين؛ الضابطة والتجريبية في التطبيق البعدي لاختبار مدخل التزكيز المبدئي على الرمز لصالح تلاميذ المجموعة التجريبية".

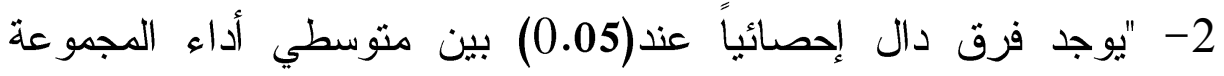

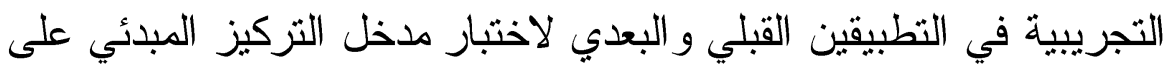
الرمز لصالح التطبيق البعدي للاختبار".

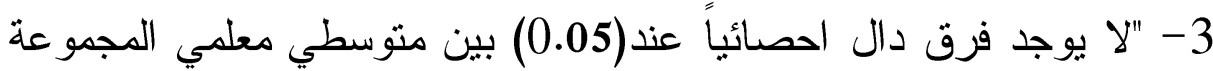

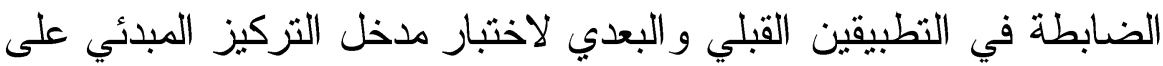
الرمز".

4- "يوجد فرق دال إحصائياً عند(0.05) بين متوسطي المجمو عتين الضابطة و التجريبية في التطبيق البعدي لبطاقة الملاحظة لصالح معلمي المجموعة التجريبية".

5- "يوجد فرق دال إحصائياً عند(05) بين متوسطي التطبيقين؛ القبلي و البعدي لبطاقة الملاحظة على المجموعة التجريبية لصالح التطبيق البعدي". 
6- "لا يوجد فرق دال احصائياً عند(0.05) بين متوسطي الأداء للمجموعة الضابطة في التطبيقين؛ القبلي و البعدي لبطاقة الملاحظة".

$$
\text { 3- 3 - مصطحات الاراسة: }
$$

سوف تلتزم الدر اسة بالتعريفات الإجر ائية النالية:

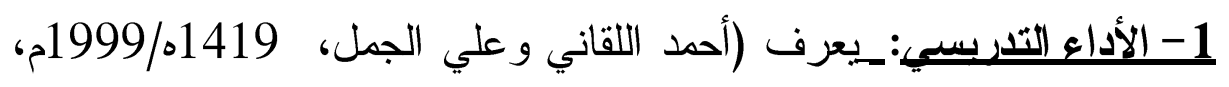

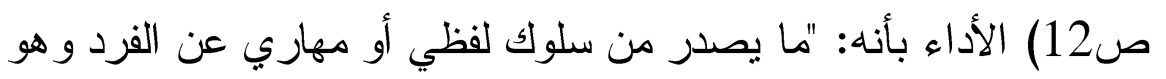

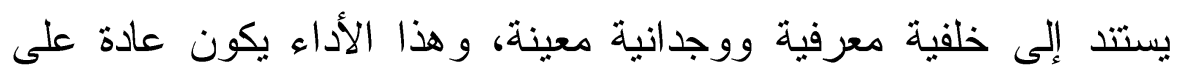

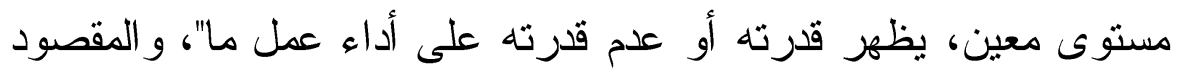

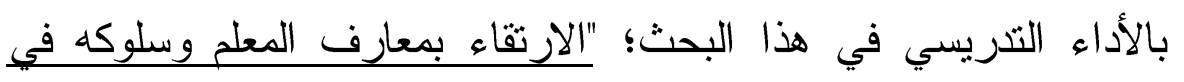

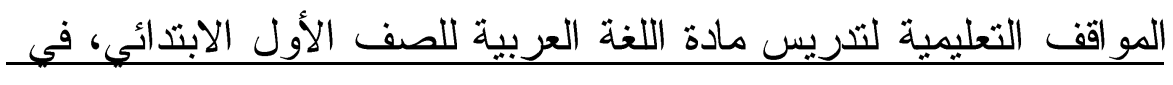

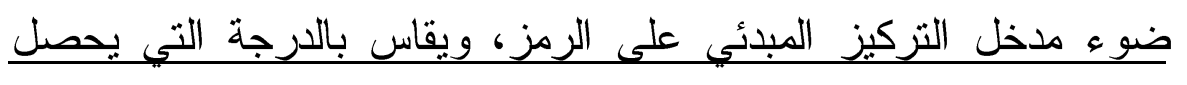

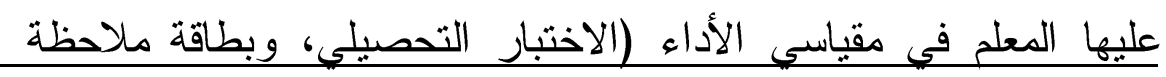
الأداء) الذين أعدهما الباحث".

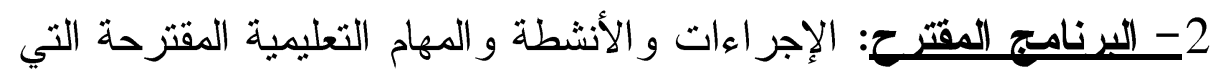

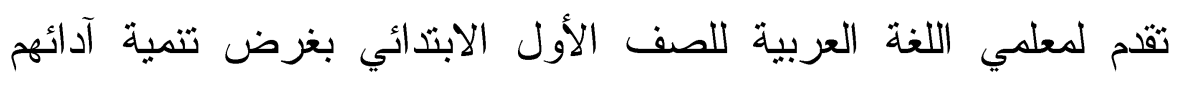

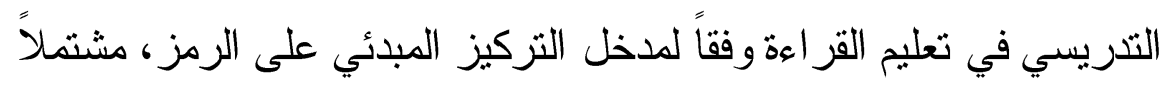

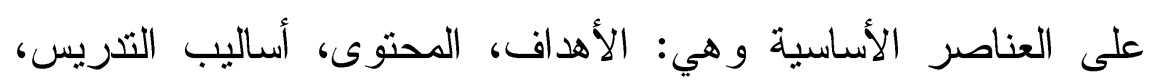
الوسائل التعليمة، أساليب التثويم.

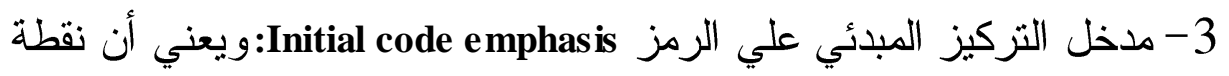
البدء في تعليم القراءة هي التزكيز علي تعليم أوجه النطابق بين وحدة التردئ

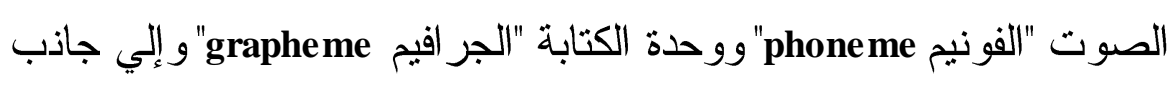
إجادة المتعلمين فلك الترميز يجب بدرجة ما الاهتمام بتتمية المهارات الأخرى اللازمة للقر اءة الناضجة كالفهم وغيره. doi : 10.12816/0001054 


\section{• أهمبة (الداسية:}

تزجع أهمية هذه الدر اسة إلى ما تقمه لميدان تعليم اللغة العربية من إسهامات؛ أهمها: ترجع 1- برنامجاً تدريبياً محكماً يمكن استخدامه بسهولة ويسر لتذريب معلمي اللغة العربية في الصف الأول الابتدائي على استخدام الطريقة الصوتية في تعليم

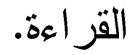

2- اختبارًا في مدخل التركيز المبدئي على الرمز يمكن استخدامه لتحديد

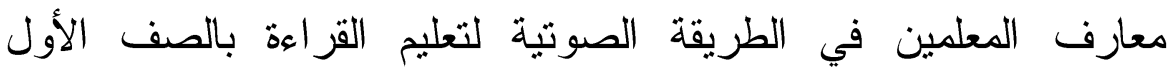
الابتدائي، ويمكن النسج على منو اله لعمل اختبار ات مشابهة للمعلمين في بهي جميع المو اد و المر احل التعليمية. 3- بطاقة ملاحظة مزودة بقو اعد التقدير المتدرجة لتحديد درجة أداء المعلم، لهوله يمكن استخدامها لقياس مهار ات الأداء للمعلمين في المو اقف التعليمية أثناء تعليم القر اءة للمبتدئين، أو النسج على مهن منو الها. 4- مادة علمية حول تعليم القراعة بالطريقة الصوتية يستقيد منها المعنيون

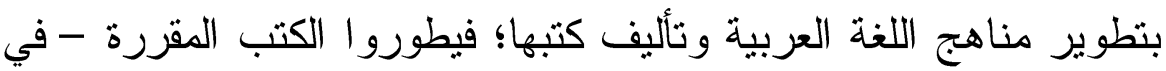
ضوئها - لمساعدة الأطفال علي فهم مبدأ الألفباء منذ بداية تعليمهم القر اءة.

\section{ثانياً: احر اعلت الادرسة:}

البرنامج؛ تصميمه، وتتفيذه:

يرى الباحث أن النماذج الخاصة بتصميم البرامج التنريبية تختلف من حيث الخطوات التي تبنى عليها غير أنها تتفق في المكونات الأساسية؛ كتحديد الحاجات التدريبية وتحليلها، وكتابة الأهداف، وتحديد المحتوى، و الأنشطة التذريبية و الوسائل المساندة، و التقويم بصورة منظمة، و التغذية الر اجعة، وقد استفاد الباحث من تلك النماذج التذريبية - بالدر اسات السابقة - في تكوين 
وتصميم البرنامج التدريبي المقتر حلذا البحث، حيث يتكون من ثلاث مر احل

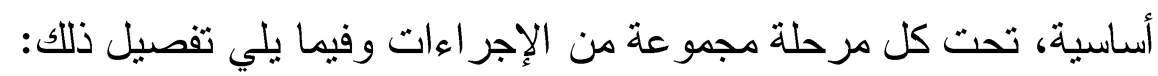

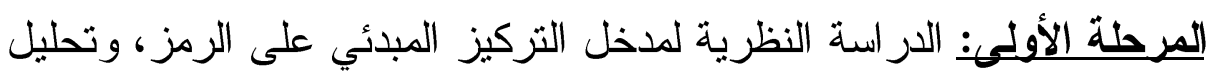

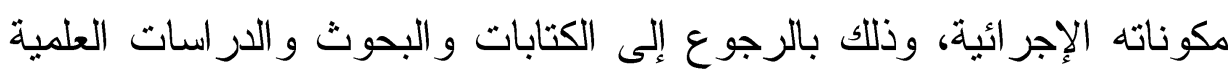

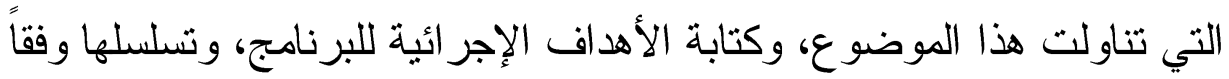
لمكونات المدخل، وتحديد مفردات المحتوى و الأنشطة التكريبية. المرحلة الثانبة: تنظيم وتصميم المحتوى العلمي الذي يدعم الأهداف الإجر ائية

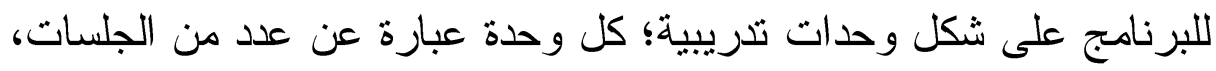
وكل جلسة محددة المدة و الهدف، و الموضوع، و المادة العلمية، و الأدوات

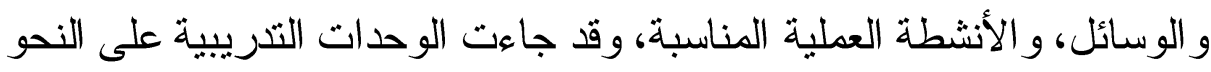
التالي: اللوحدة الأولمى: مدخل التركيز المبدئي على الرمز؛(دفهومه، أسسه،أهدافه،

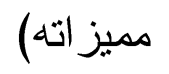

الجلسة التدريبية الأولى: مفهوم و أسس مدخل التركيز المبدئي على الرمز . الجلسة التريبية الثانية: أهداف ومميزات تعليم القزاعة وفق مدية مدخل التركيز المبدئي على الرمز.

الوحدة الثانية: إجر اءات تعليم القر اعة من منظور مدخل التركيز المبدئي على لـ الرمز.

الجلسة التدريبية الأولى: التهيئة - تنمية المهار ات (القر ائية/ الكتابية). الجلسة التدرييية الثانية: التدريب على الاستماع- التدريب على التحدث- تعليم القيم و الاتجاهات. 
الوحدة الثالثة: إعداد خطة استرشادية لارسين؛ أحدها يعالج تعليم الحروف، و الآخر يعالج تعليم نص قرائي، وذللك وفق مقتضيات مدخل

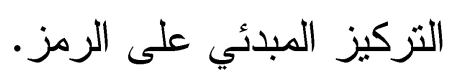

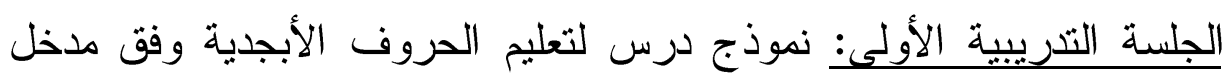

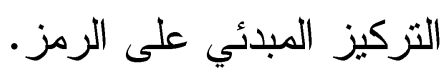

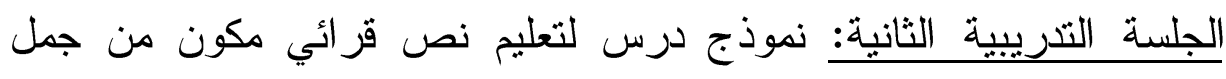

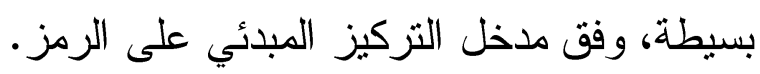

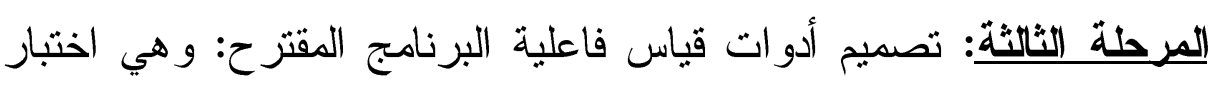
المدخل، وبطاقة الملاحظة، وقد كان ذلك على النحو التالي: أ - اختبار مدخل التركيز المبئي على الرمز - من إعداد الباحث:

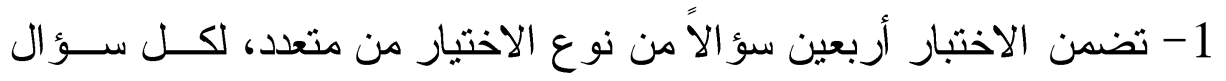

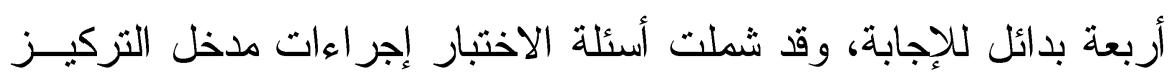

$$
\text { المبدئي على الرمز، كما يوضحه ملحق (1). }
$$

2- تم التحقق من صدق الاختبار عن طريق عرضده - في صورته المبدئية-

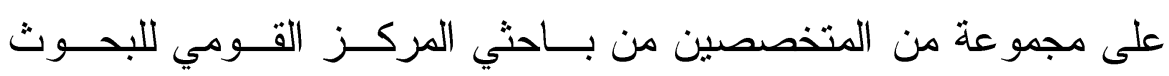

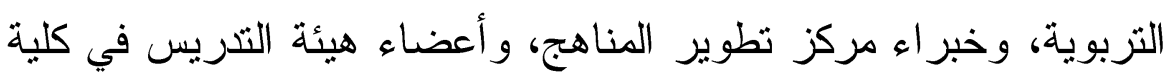

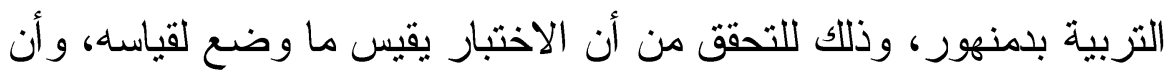

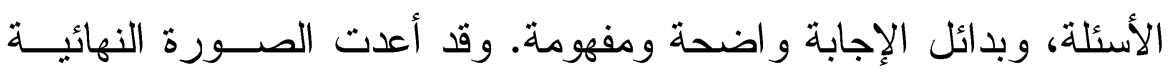

$$
\text { للاختبار في ضو ء ملاحظاتهم، وتعليقاتهم. }
$$

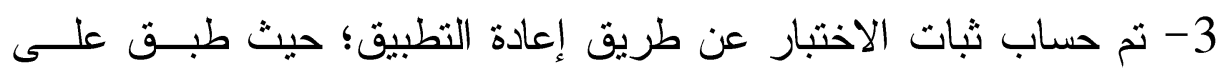

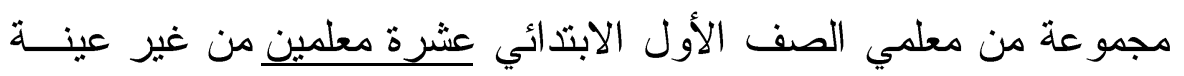
الدر اسة، ثخ أعيد تطبيقه على نفس المجموعة بعد مرور 30 ثلاثين يوماً، وحسب معامل الارتباط بين مرتي التطبيق، فكان (0.83)

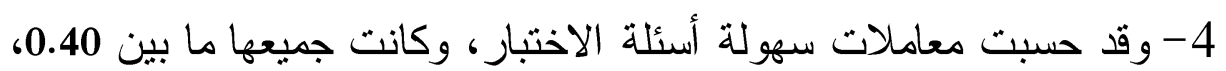

$$
\text { و0.68 و هي موضحة بالملحق رقم (2). }
$$


5- أكدت التجربة أن الوقت اللزم للإجابة عن الاختبار في حدود (60)دقيقة،

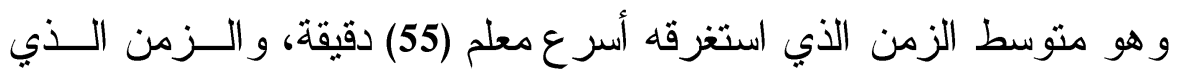
استغرقه أبطأ معلم (65) دقيقة. ب - بطاقة ملاحظة أداء المتدرب - من إعداد الباحث: 1- و هي عبارة عن استمارة شملت (16) ممارسة صفية لرصد إعلداب السلوك التعليمي

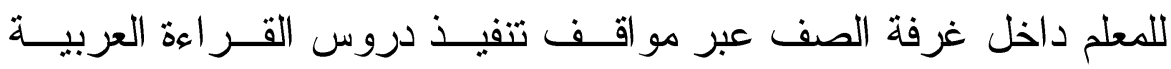

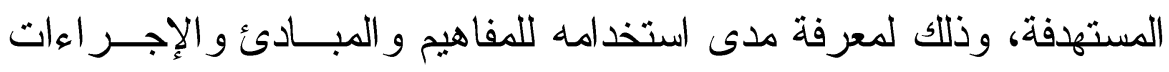

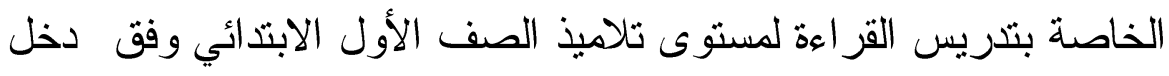
التركيز المبدئي على الرمز، كما يوضحه ملحق رقم (3).

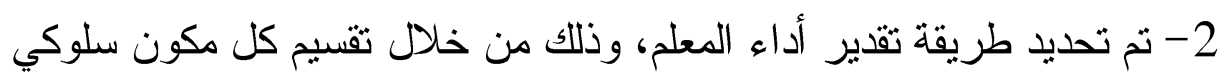

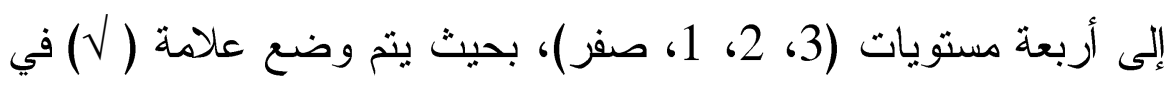

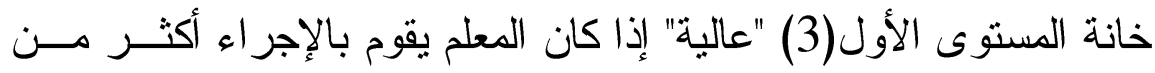
مرتين، وتوضع العلامة في خانة المستوى الثاني(2) "متوسطة" إذا كـان لئان

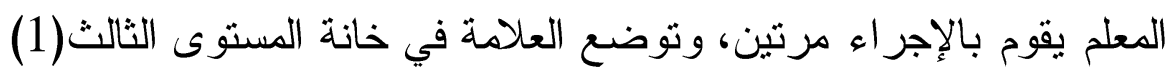

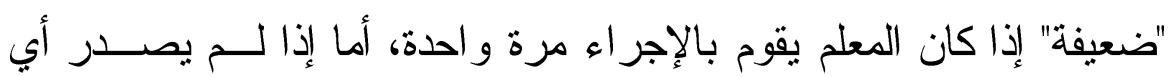
سلوك من المعلم فتوضع العلامة أمام الخانة الر ابعة (صفر) "معدومة". 3- وللتحقق من سلامة ودقة البيانات التي تزودنا بها بطاقة الملاحظة، كـان العـان

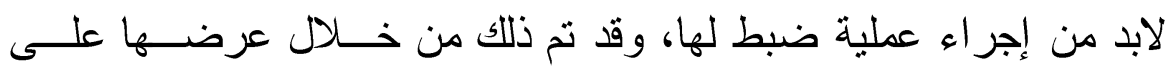

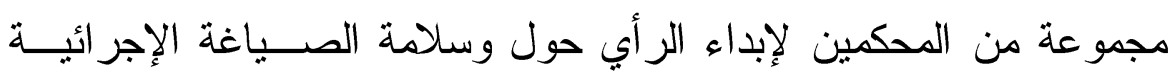

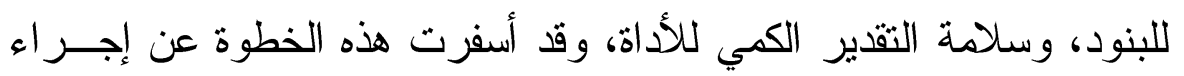
بعض التعديلات في صياغة بعض البنود. 
4- حساب ثبات بطاقة الملاحظة: وذلك بتجربتها على عينة استطلاعية مكونة

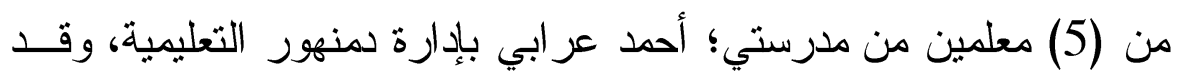

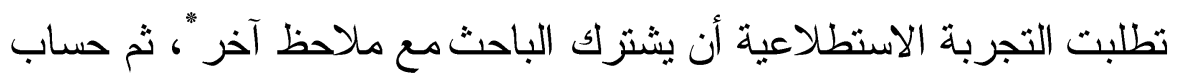

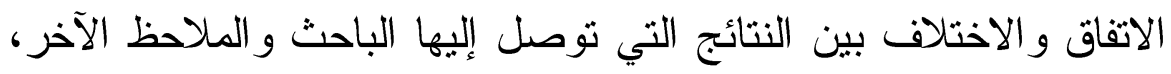
بحيث يمكن التأكد من ثبات البطاقة إذا وصلت درجة التطابق بين النتيجتين

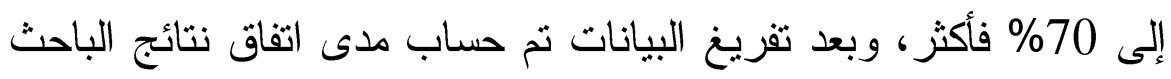

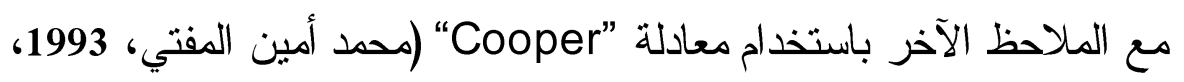
عدد مر ات الاتفاق صن262. (16)

$100 \times$ نسبة الاتفاق

عدد مرات الاتفاق + عدد مرات الاختلاف وقد جاءت النتائج كما هي مبينة بالجدول الآتي:

جدول (1) يوضح نسب الاتفاق بين الملاحظين

\begin{tabular}{|c|c|c|c|c|}
\hline معامل الاتفاق (الثبات) & عدد مرات الاختلاف & عدد مرات الاتفاق & عدد البنود & المعلمين \\
\hline 75 & 4 & 12 & 16 & الاول \\
\hline 87.5 & 2 & 14 & 16 & الثاني \\
\hline 75 & 6 & 12 & 16 & الثالث \\
\hline 75 & 4 & 12 & 16 & الر ابع \\
\hline 81.25 & 3 & 13 & 16 & الخامس \\
\hline
\end{tabular}

نتضح من الجدول السابق أن أعلى نسبة اتفاق وصلت (87.5) تقريباً، و أقل

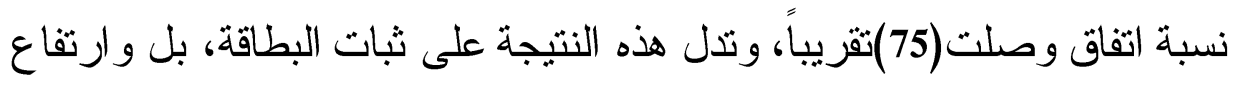
مستوى الثبات كما أثنار إلى ذلك "cooper" حيث أوضح أن نسبة الإتفاق إذا ولثا انخفضت عن (70\%) فهذا يدل على انخفاض مستوى الثبات، بينما إذا بلغت

*د. جمعة شيخ روحه - خبير اللغة العربية بمركز تطوير المناهج بوزارة التربية والتعليم. 
نسبة الاتفاق (85\%) فأكثر فهذا يدل على ارتفاع مستوى الثبات، وبعد التأكد من صدق البطاقة وثباتها تكون في صورتها النهائية. - - ضبط البرنامج التدريبي المقترح: تم عرض البرنامج التدريبي المقترح

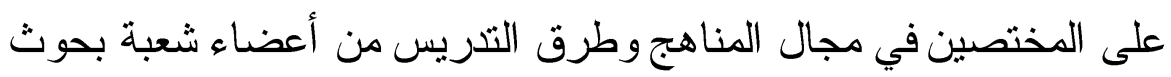
تطوير المناهج بالمركز القومي للبحوث التزبوية، وخبر اء مركز تطوير

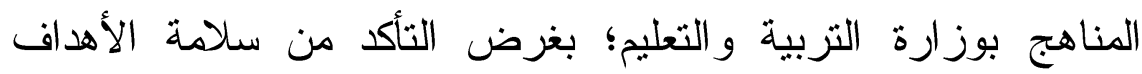

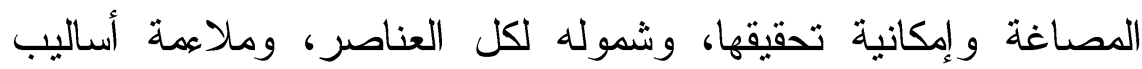

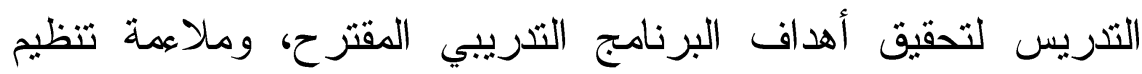
المحتوى ووحداته للأهداف، ومناسبة الأنشطة و الوسائل المقترحة، ومناسبة لئرئ

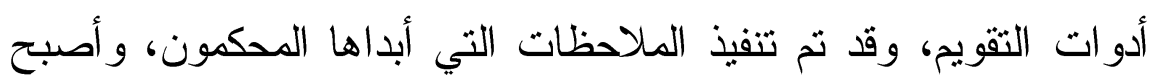
البرنامج في صورته النهائية، كما في ملحق رقم (4).

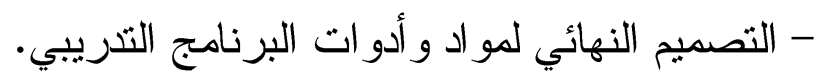
- القيام بالإجر اءات الإدارية لتسهيل تطبيق البرنامج التّريبي على عينة البحث من إمكانات مادية وفنية.

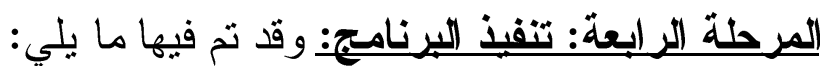

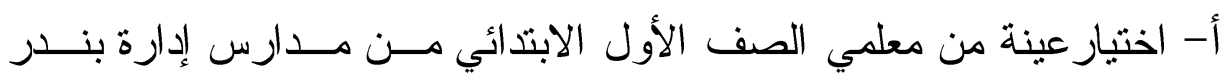

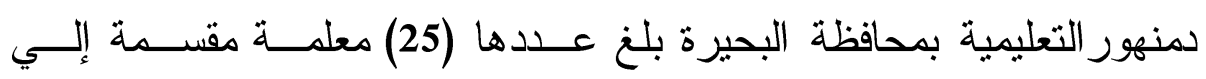
مجمو عتين هي التجريبية(14) معلماً ومعلمة، و الضابطة (11) معلماً ومعلمة، وقد تم اختيار العينة بطريقة شبه عثو ائية (وفق ما أتيح للباحث من مدارس بها معلمين متعاونون ولديهم استعداد للتدريب، وتتفيذ ما تم التدريب عليه). ب- إجر اء التقويم القبلي على عينة البحث بوساطة اختبار المدخل وبطاةـــة

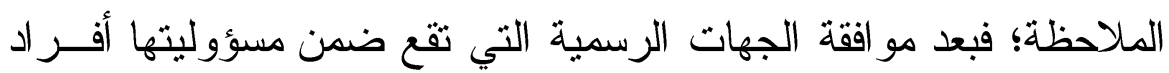

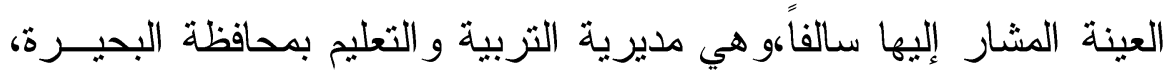
doi : 10.12816/0001054 
بموجب طلب تقلم به الباحث، تم إجر اء التقويم القبلي على عينة البحــث، حيث تم تطبيق اختبار مدخل التركيز المبدئي على الرمز، وبطاقة الملاحظة

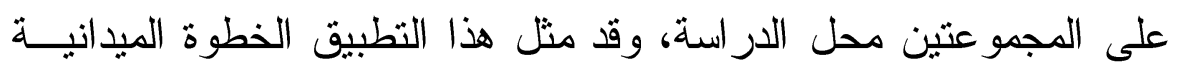

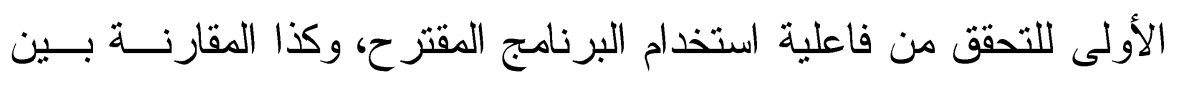
المجمو عتين؛ الضابطة والتجريبية في الاختبار القبلي (التكافؤ) باســتخدام اختبار "ت" لهجموعتين مستقلتين، وكانت النتائج على النحو التالي: التئي

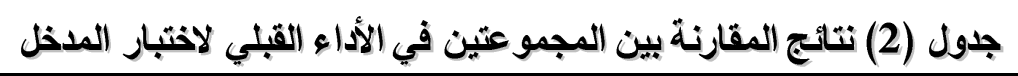

\begin{tabular}{|c|c|c|c|c|c|c|}
\hline الالالة عند & ت & درجات & الالمعر افي المعياري & المتوسط & ن & المجموعة \\
\hline \multirow[t]{2}{*}{ غير دال } & \multirow[t]{2}{*}{1.296} & \multirow[t]{2}{*}{26} & 2.786 & 11.93 & 14 & التجريبية \\
\hline & & & 2.128 & 10.71 & 14 & الضابطة \\
\hline
\end{tabular}

يتضح من الجدول السابق انه لا يوجد فرق دال إحصائياً عند(0.05) بين

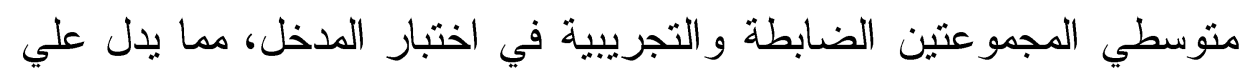
تكافؤ المجموعتين في القياس القبلي للاختبار . جدول (3) نتائج المقارنة بين المجموعتين في التطبيق القبلي لبطاقة الملاحظة

\begin{tabular}{|c|c|c|c|c|c|c|}
\hline الدالة عند 0.05 & ت & دالدرية & المعياري & المتوسط & ن & المجموعة \\
\hline \multirow[t]{2}{*}{ غير دال } & \multirow[t]{2}{*}{0.773} & \multirow[t]{2}{*}{26} & 1.359 & 16.00 & 14 & التجريبية \\
\hline & & & 2.409 & 16.57 & 14 & الضابطة \\
\hline
\end{tabular}

يتضح من الجدول السابق انه لا يوجد فرق دال إحصائياً عند (0.05) بين

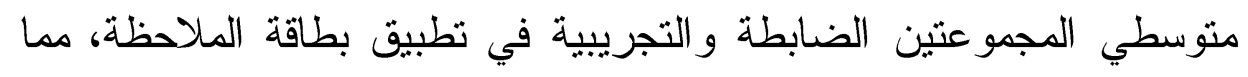
يدل علي تكافؤ المجمو عتين في التطبيق القبلي للبطاقة.

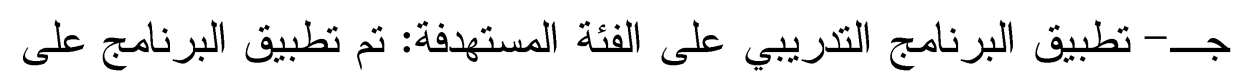

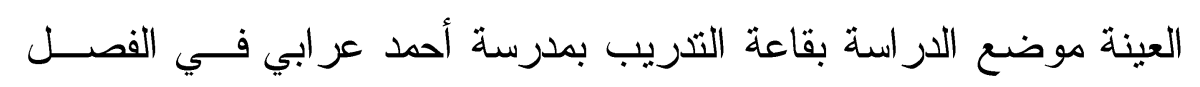

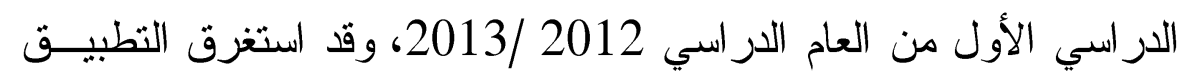


مدة ثلاثة أيام في الفتزة من 15/ 10- 17/ 2012/10، بمعدل خمسس ساعات يومياً.

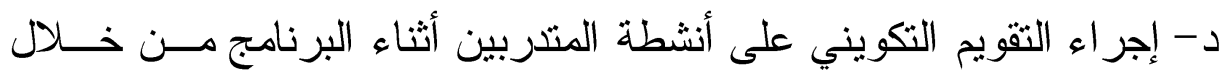

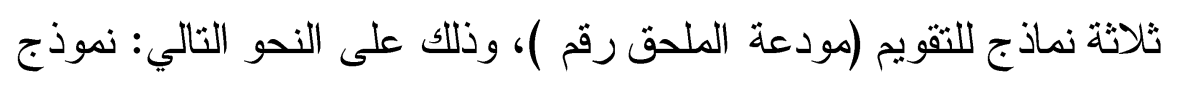

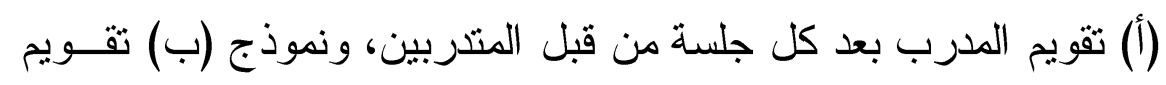

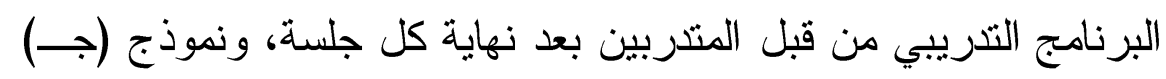

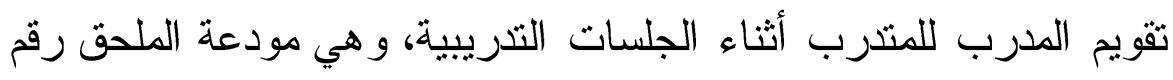

هـ إجراء النتويم البعدي على عينة البحث بنطبيق اختبار الدخل وبطاقــة الماحظة.

و - تحليل النتائج ومعالجتها إحصائياً، باستخدام الأساليب الإحصائية التاليــة:

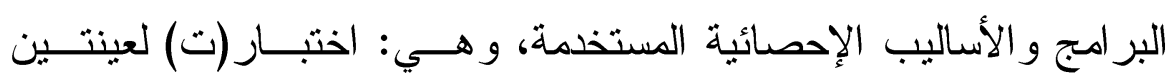

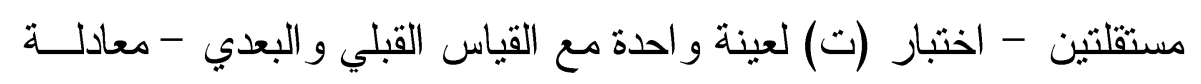

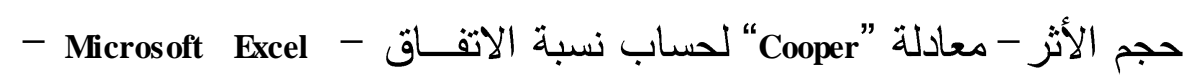

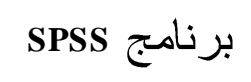
ز - عرض النتائج وتفسير ها؛ وذللك كما يلي: 1 - أن عرض النتاتج::

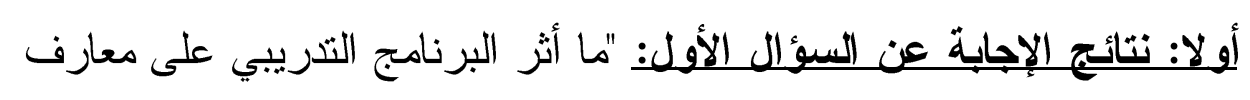

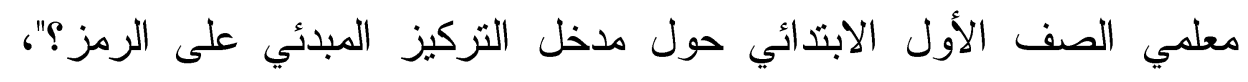

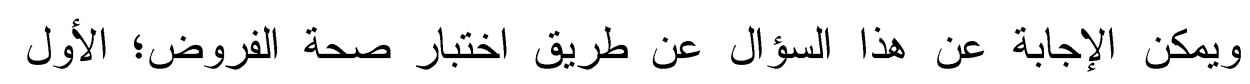
و الثاني و الثالث. ولاختبار صحة الفرض الأول: "يوجد فرق دال الحصائباً عند (05.0.0) بين

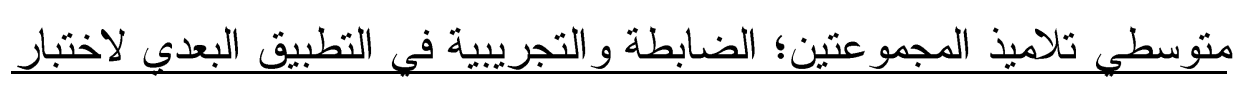
doi : 10.12816/0001054 
مدخل التركيز المبئي على الرمز لصالح تلاميذ التجريبية"، تم استخدام اختبار

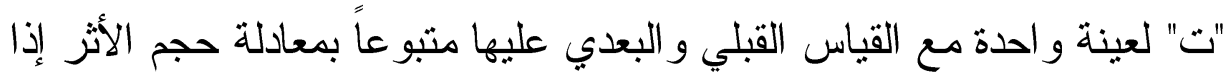

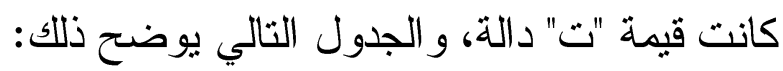
جدول (4): المقارنة بين المجموعتين الضابطة والتجريبية في الاختبار البعدي لهون

\begin{tabular}{|c|c|c|c|c|c|c|c|}
\hline الاثر & (لالالة عند 0.05 & 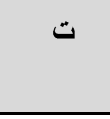 & العرجية & المعياري & المتوسط & ن & المجموعة \\
\hline 4.82 & \multirow[t]{2}{*}{ دال } & \multirow[t]{2}{*}{12.294} & \multirow[t]{2}{*}{26} & 4.582 & 31.07 & 14 & التجريبية \\
\hline كبير & & & & 2.495 & 13.93 & 14 & الضابطة \\
\hline
\end{tabular}

يتضح من الجدول السابق أن قيمة "ت" دالة عند (0.05) مما يدل علي وجود فرق دال بين تلاميذ المجموعتين؛ الضابطة والتجريبية في التطبيق البعدي

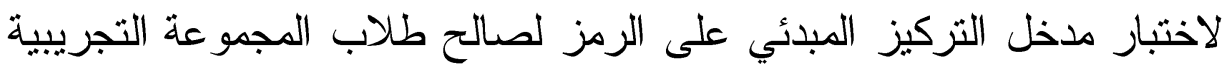

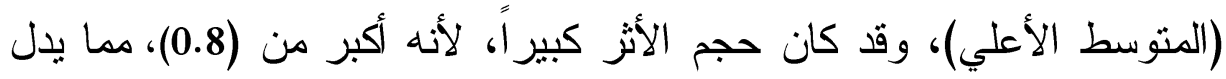

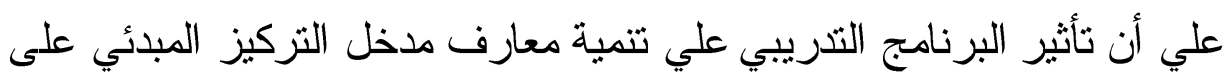

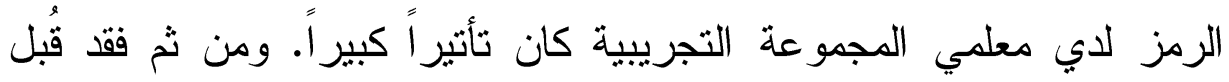
الفرض الأول من فروض الارسة. ويمكن تمثيل متوسطي المجموعتين بيانياً

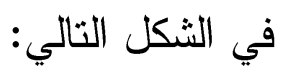

شكل (1): التمثيل اليياني لمتوسطي الأداء للمجمو عتين الضابطة والتجرييية في الاختبار

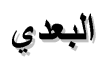

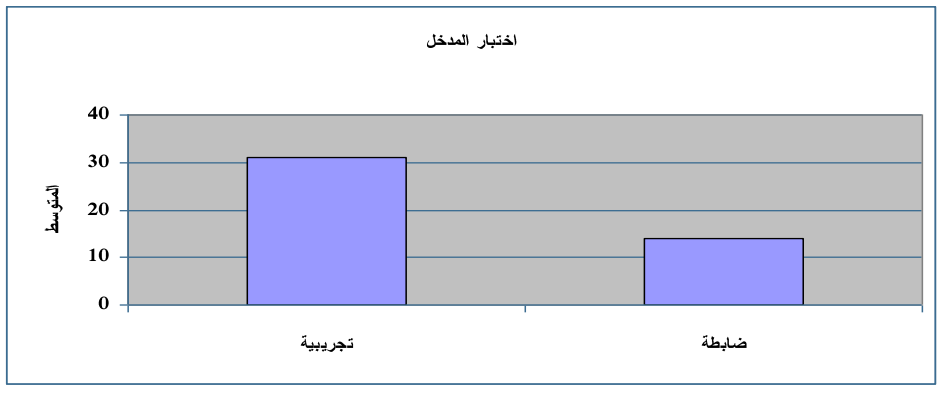

ولاختيارصحة الفرض الثاني: "يوجد فرق دال إحصائياً عند (0.05) بين متوسطي أداء المجموعة التجرييية في التطبيقين القبلي و البعدي لاختبار مدخل 
التركيز المبئي على الرمز لصالح التطبيق البعدي للاختبار"، تم استخدام

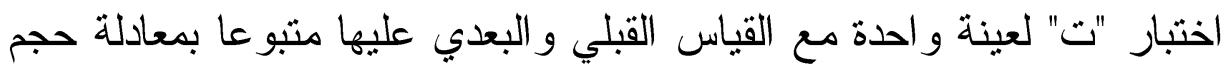

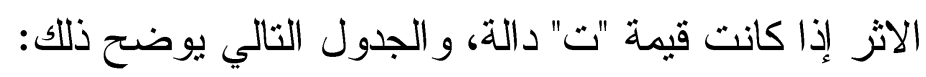
جدول (5) يوضح المقارنة بين الاختبارين القبلي و البعدي للمجموعة التجريبية

\begin{tabular}{|c|c|c|c|c|c|c|c|c|}
\hline الأثر & $\begin{array}{r}\text { علدالة } \\
0.05\end{array}$ & $ت$ & الحرية & للفري اندراف & منوسط الفروق & الإنحراف & المتوسط & القيلس \\
\hline \multirow{2}{*}{$\begin{array}{r}9.29 \\
\text { كبيز }\end{array}$} & \multirow[t]{2}{*}{ دالة } & \multirow[t]{2}{*}{16.750} & \multirow[t]{2}{*}{13} & \multirow[t]{2}{*}{4.276} & \multirow[t]{2}{*}{19.143} & 4.582 & 31.07 & بعدي \\
\hline & & & & & & 2.786 & 11.93 & قبلي \\
\hline
\end{tabular}

يتضح من الجدول السابق أن قيمة "ت" دالة عند (0.05) هما يدل علي وجود فرق دال بين معلمي المجمو عة التجريبية في التطبيقين؛ القبلي البعدي لاختبار

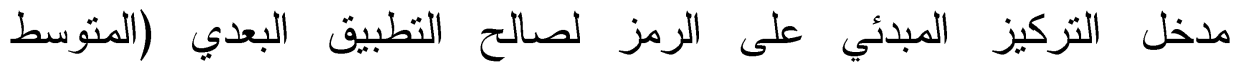
الأعلي)،وقد كان حجم الأثر كبيراً، لأنه أكبر من (0.8)، مما يدل علي أن تأثير

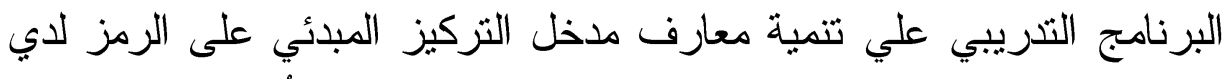

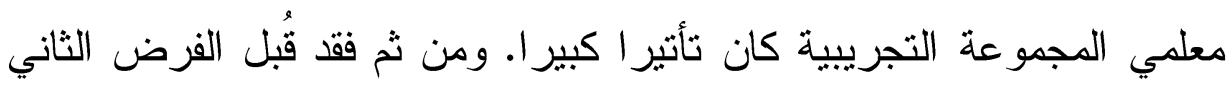

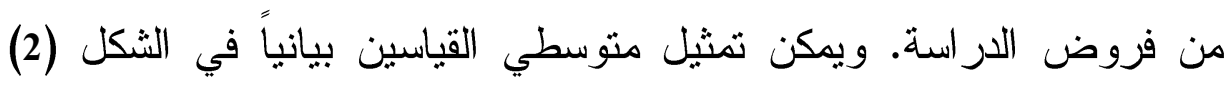

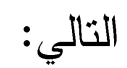

شكل (2) التمثيل اليياتي لمتوسطي الأداء القبلي والبعدي للمجموعة التجريبية

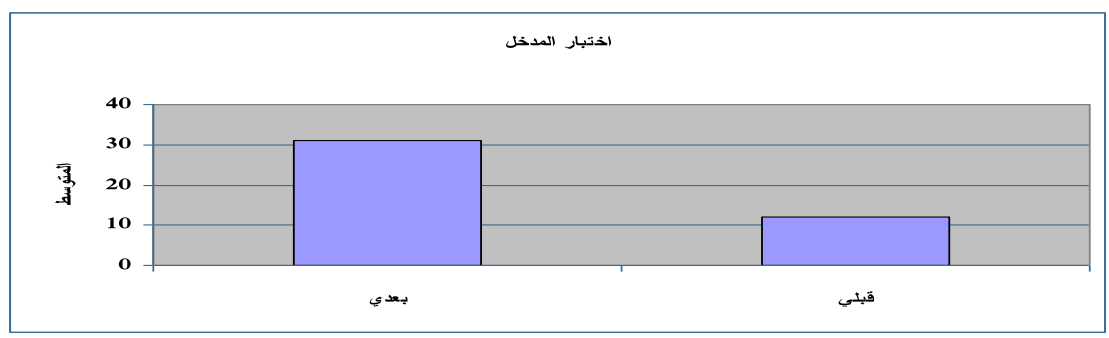

ولاختبار صحة الفرض الثالث: "لا يوجد فرق دال احصائياً عند (0.05) بين متوسطي معلمي المجموعة الضابطة في التطبيقين القبلي و البعدي لاختبار doi : 10.12816/0001054 
مدخل التركيز المبئي على الرمز"، تم استخدام اختبار "ت" لعينة واحدة مع

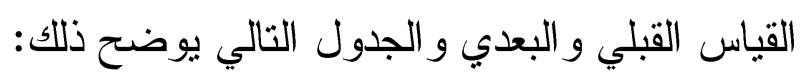

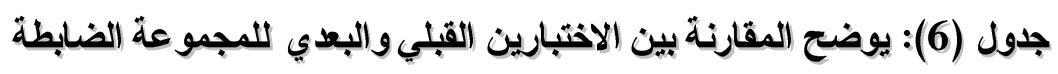

\begin{tabular}{|c|c|c|c|c|c|c|c|c|}
\hline حجم الاثر & $\begin{array}{r}\text { الدلالة } \\
0.05 \\
0.05\end{array}$ & ت & الدربة & للفرياري & الفروق & الالتحر اف & المتوسط & القياس \\
\hline 4.68 & \multirow[t]{2}{*}{ دالة } & \multirow[t]{2}{*}{8.446} & \multirow[t]{2}{*}{13} & \multirow[t]{2}{*}{1.424} & \multirow[t]{2}{*}{3.214} & 2.495 & 13.93 & بعدي \\
\hline كبير & & & & & & 2.128 & 10.71 & قبلى \\
\hline
\end{tabular}

يتضح من الجدول السابق أن قيمة "ت" كانت غير دالة عند (0.05)، مما يــدل

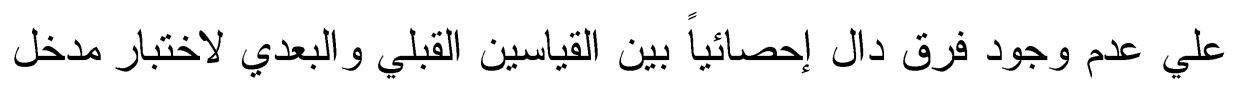

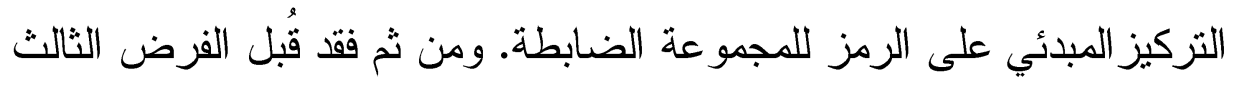

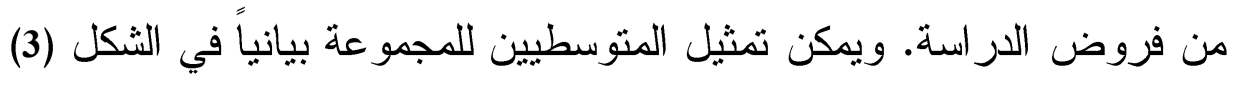
التالي: شكل (3) التمثيل البياني لمتوسطي الأداء القبلي و البعدي للمجموعة الضابطة

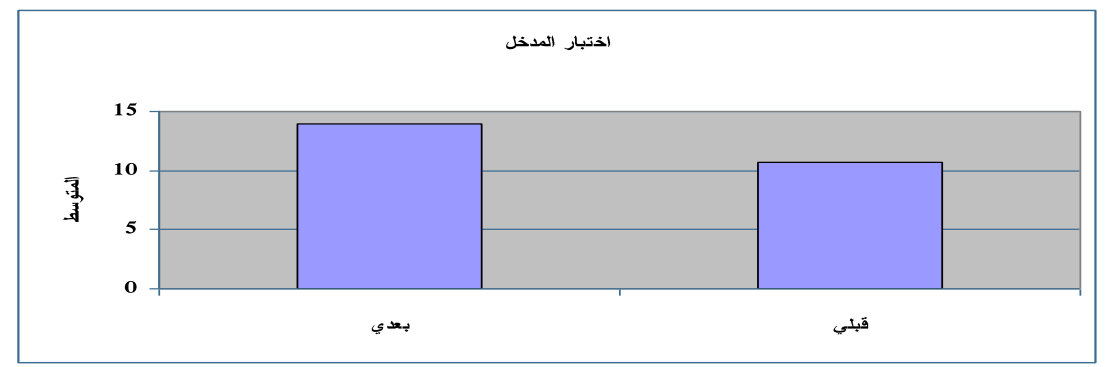

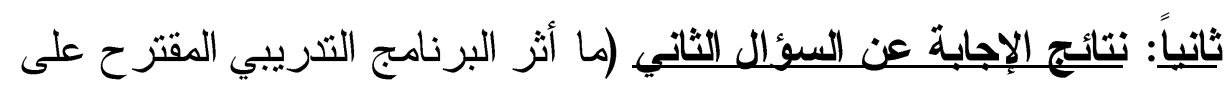

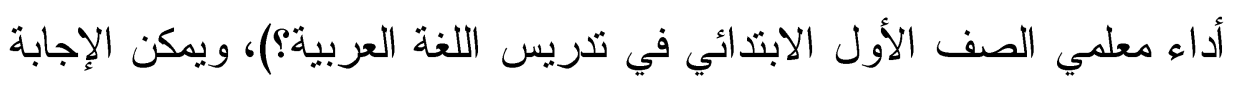

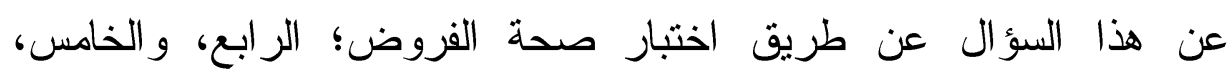
و السادس.

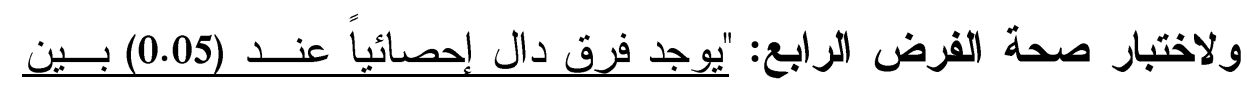
متوسطي المجمو عتين الضابطة والتجريبية في النطبيق البعدي لبطاقة الملاحظة 
لصـالح معلمي المجموعة التجريبية"، تم اســتخدام اختبــار "ت" لمجمــوعتين

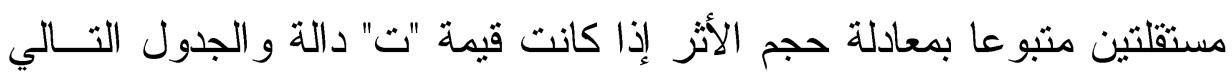
يوضح ذلك:

جدول رقم (7): يوضتح المقارنة بين المجموعتين الضابطة والتجريبية في التطبيق البعدي

\begin{tabular}{|c|c|c|c|c|c|c|c|c|}
\hline الاثر & عند 0.05 & ت & الدرجية & الالانحراف & المتوسط & ن & المجموعة & الاداة \\
\hline 7.57 & \multirow[t]{2}{*}{ دال } & \multirow[t]{2}{*}{19.302} & \multirow[t]{2}{*}{26} & 1.906 & 32.36 & 14 & التجريبية & \multirow{2}{*}{ الملاحظة } \\
\hline كبير & & & & 2.287 & 17.00 & 14 & الضابطة & \\
\hline
\end{tabular}

يتضح من الجدول السابق أن قيمة "ت" دالة عند (0.05) مما يدل علي وجود

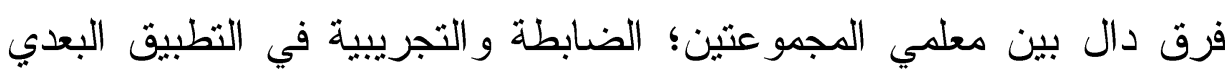
لبطاقة الملاحظة لصالح معلمي المجموعة التجريبية (المتوسط الأعلي)، وقد كان حجم الأثز كبيراً، لأنه أكبردن(0.8)، مما يدل علي أن تأنير البرنامج

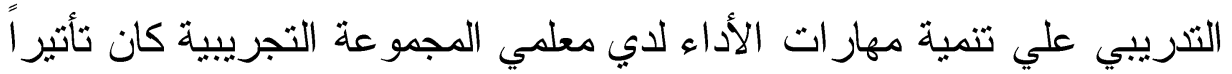
كبيراً.ومن ثم فقد قُبل الفرض الأول من فروض الاراسة.ويمكن تمثيل منوسطي المجمو عتين بيانياً في الثكل التالي: شكل (4) :التمثيل البياني لمتوسطي الأداء للمجموعثين الضابطة والتجريبية في التطبيق البعدي

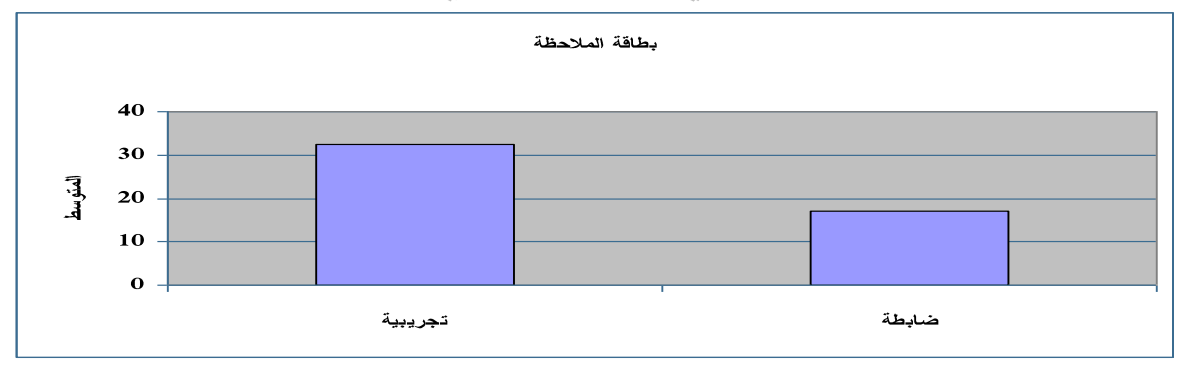


ولاختبار صحة الفرض الخامس: "يوجد فرق دال إحصائبًاً عند (0.05) بين منوسطي النطبيقين؛ القبلي و البعدي لبطاقة الملاحظة على المجمو عة التجريبية

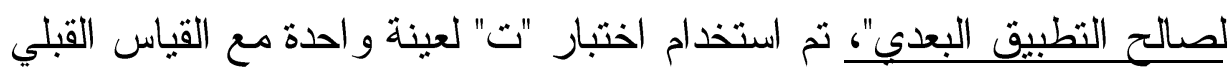

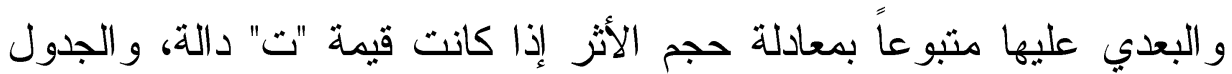
التالي يوضح ذللك: جدول(8): المقارنة بين التطيقين القبلي والبعي لبطاقة الملاحظة على لمجموعة التجريبية

\begin{tabular}{|c|c|c|c|c|c|c|c|c|}
\hline حجم الأثر & الالالة عذد 0.05 & ت & الحرية & معياري للفروق & الفروق & الالمعر اف & المتوسط & القياس \\
\hline 13.58 & \multirow[t]{2}{*}{ دالة } & \multirow[t]{2}{*}{24.49} & \multirow[t]{2}{*}{13} & \multirow[t]{2}{*}{2.50} & \multirow[t]{2}{*}{16.36} & 1.91 & 32.36 & بعدي \\
\hline كبير & & & & & & 1.36 & 16.00 & قبثي \\
\hline
\end{tabular}

يتضح من الجدول السابق أن قيمة "ت" دالة عند (0.05)، مما يدل علي وجود

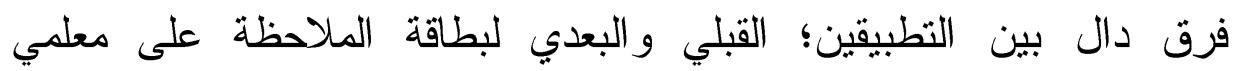

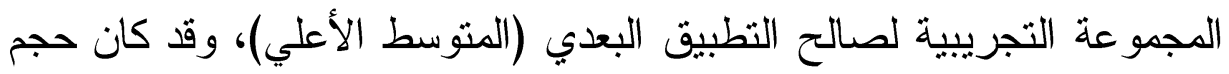

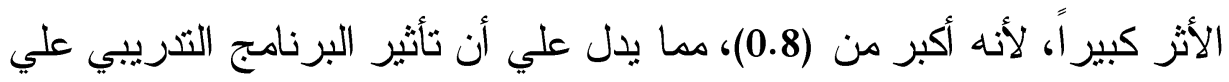

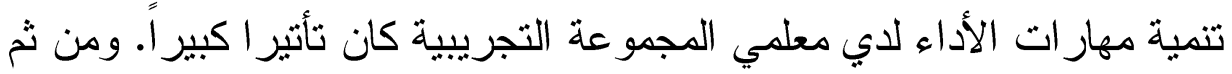
فقد قُبل الفرض الخامس من فروض الدراسة. ويمن تمثيل متوسطي المجمو عتين بيانياً في الثكل (5) التالي: شكل (5) :التمثيل البياني لمتوسطي الأداء القبلي والبعدي للمجموعة التجريبية

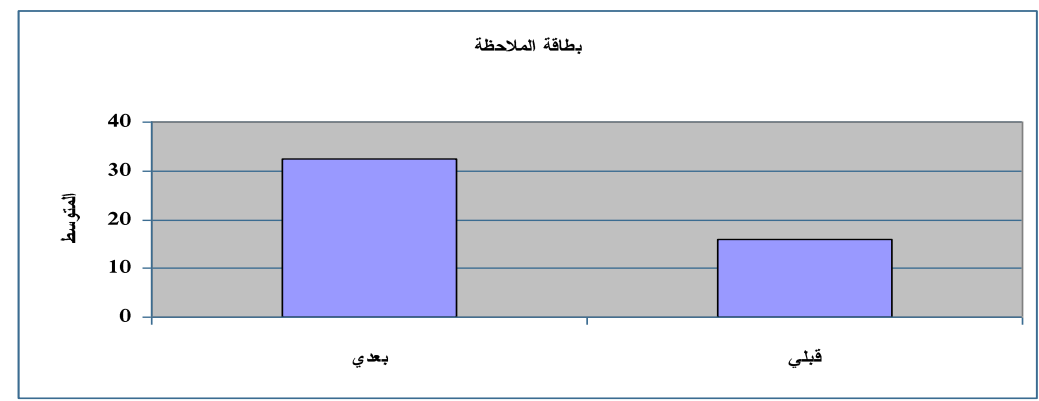

و الصورة التفصيلية للنتائج تتضح من الجدول التالي: 
أثر تدريب معلمي اللغة العربية للصف الأول الابتدائي في ضوء مدخل الثركيز المبائي د. محمد أبوزهرة

جدول (9) :المتوسطين؛ القبلي والبعدي والنسبة المئويـة لهما لكل مفردة للمجموعة

التجريبية

\begin{tabular}{|c|c|c|c|c|c|}
\hline المئوية له & البعديط & النسبة المئوية & المتوسط القبلي & الارجة & البنود \\
\hline 88.00 & 2.64 & 66.67 & 2.00 & 3 & 1 \\
\hline 78.67 & 2.36 & 66.67 & 2.00 & 3 & 2 \\
\hline 64.33 & 1.93 & 43.00 & 1.29 & 3 & 3 \\
\hline 76.33 & 2.29 & 19.00 & 0.57 & 3 & 4 \\
\hline 66.67 & 2.00 & 52.33 & 1.57 & 3 & 5 \\
\hline 52.33 & 1.57 & 19.00 & 0.57 & 3 & 6 \\
\hline 50.00 & 1.50 & 23.67 & 0.71 & 3 & 7 \\
\hline 83.33 & 2.50 & 33.33 & 1.00 & 3 & 8 \\
\hline 45.33 & 1.36 & 23.67 & 0.71 & 3 & 9 \\
\hline 85.67 & 2.57 & 62.00 & 1.86 & 3 & 10 \\
\hline 66.67 & 2.00 & 4.67 & 0.14 & 3 & 11 \\
\hline 69.00 & 2.07 & 28.67 & 0.86 & 3 & 12 \\
\hline 78.67 & 2.36 & 43.00 & 1.29 & 3 & 13 \\
\hline 66.67 & 2.00 & 14.33 & 0.43 & 3 & 14 \\
\hline 57.00 & 1.71 & 19.00 & 0.57 & 3 & 15 \\
\hline 50.00 & 1.50 & 14.33 & 0.43 & 3 & 16 \\
\hline 67.42 & 32.36 & 33.33 & 16.00 & 48 & المجموع \\
\hline
\end{tabular}

وباستقر اء الجدول السابق يتضح أن:

- بالتسبة للأداء القبلي:

• حصل البند(1) "البدء بالمتطلبات القبلية اللزمة لتعليم القراءة؛ كتقديم الحروف الهجائية بأصواتها، و التدريب علي مهار ات التمبيز بينها رسما ونطقا"، في بطاقة الملاحظة على أعلى متوسط (2.00) بنسبة مئوية قدر ها

.$(\% 66.67)$

• حصل البند رقم (11) "تنمية مهار ات الفهم عند تعلم أول وحدة لغوية تذل علي معني؛ كفه أثز القيم الخلافية للأصوات فى تشكيل المعنى، وتمبيز الصو اب من الخطأ، و إعادة ترتيب الحروف لتكون كلمة لها معنى، و إعادة doi : $10.12816 / 0001054$ 
ترتيب كلمتي الجملة.." على أقل متوسط في القائمة (0.14) بنسبة مئوية

$$
\text { قدر ها (4.67\%). }
$$

• تر اوحت متوسطات بقية بنود القائمة بين متوسط (1438) (0.43) ونسبة مئوية قررها

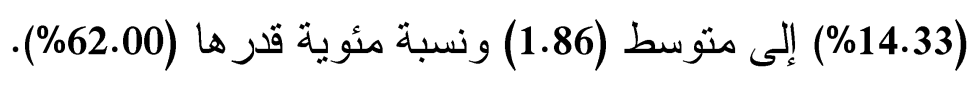

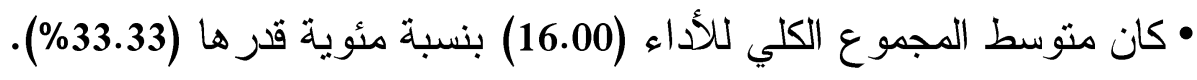

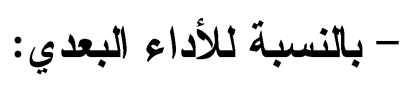

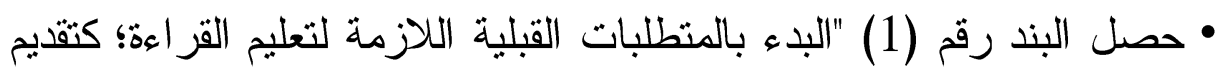

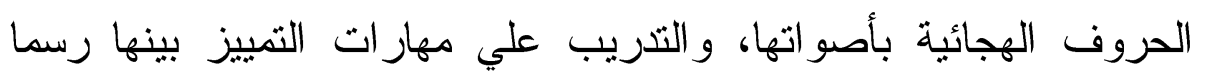
ونطقا" في بطاقة الملاحظة على أعلى متوسط (2.64) بنسبة مئوية قرزها هابها . $1 \% 88.00)$

• عصل البند رقم (9) "تعزيز المهارات النى سبق دراستها" على أقل متوسط في القائمة (1.36) بنسبة مئوية قدر ها (45.33\%).

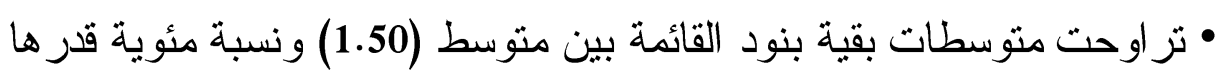
(50.00\%) إلى منو سط (2.50) ونسبة مئوية قدر ها (83.33\%).

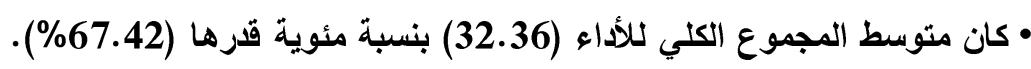
ويمكن تمثيل المتوسطين؛ القبلي و البعدي لكل مفردة، و المجموع الكلي لهما بيانياً في الثكلين (6)، (7) التاليين: شكل (6): يوضح المتوسطين؛ القبلي و البعدي لكل مفردة في بطاقة الملاحظة

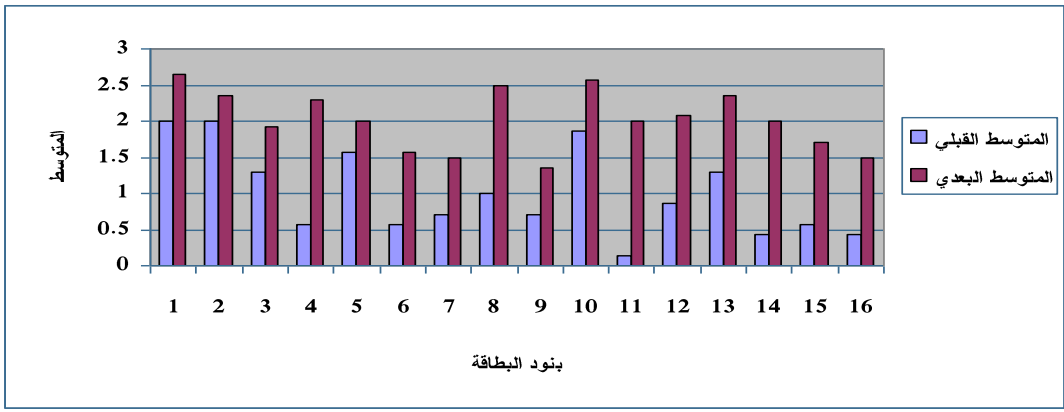


شكل (7) :يوضح التمثيل البياني للمجموع الكلي للمتوسطين؛ القبلي والبعدي لبطاقة الملاحظة

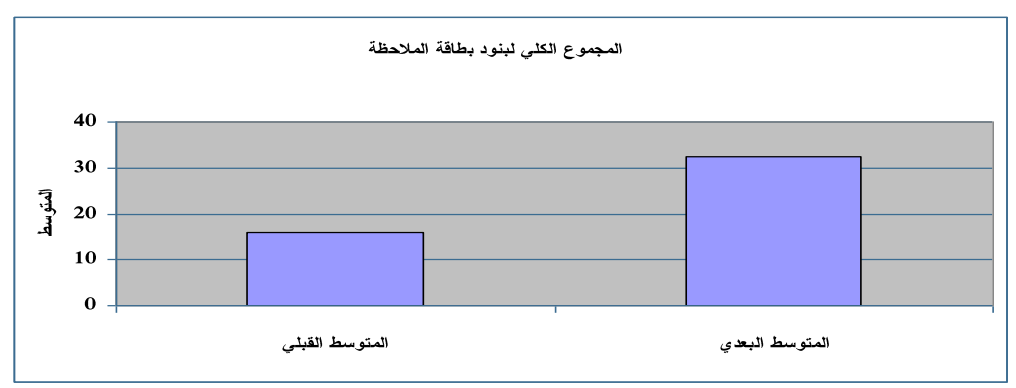

ولاختبار صحة الفرض السادس: "لا يوجد فرق دال احصائياً عند (0.05) بين

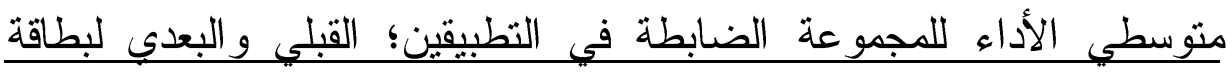
الملاحظة"، تم استخدام اختبار "ت" لعينة واحدة مع القياس القبلي و البعدي، و الجدول التالي يوضح ذلك:

جدول (10) يوضح المقارنة بين الاختبارين القبلي والبعي للمجموعة الضابطة

\begin{tabular}{|c|c|c|c|c|c|c|c|}
\hline الدالالة عذد 0.05 & 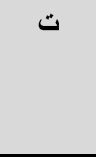 & لدرجات & للفرياري & متوسط & الالحر اف & المتوسط & القياس \\
\hline \multirow[t]{2}{*}{ غير دالة } & \multirow[t]{2}{*}{0.405} & \multirow[t]{2}{*}{13} & \multirow[t]{2}{*}{3.956} & \multirow[t]{2}{*}{0.429} & 2.287 & 17.00 & بعدي \\
\hline & & & & & 2.409 & 16.57 & قبلي \\
\hline
\end{tabular}

يتضح من الجدول السابق أن قيمة "ت" كانت غير دالة عند (0.05) مما يدل

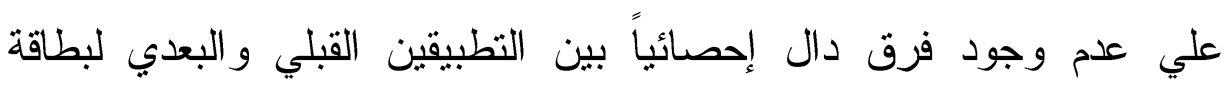

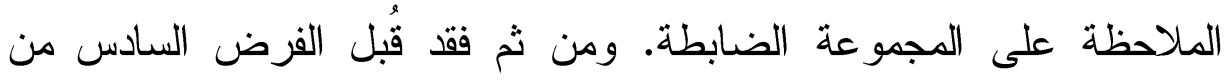

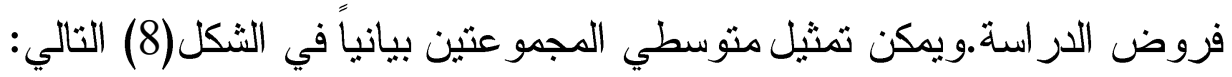
شكل (8) التمثيل البياني لمتوسطي الأداء القبلي والبعدي للمجموعة الضابطة 


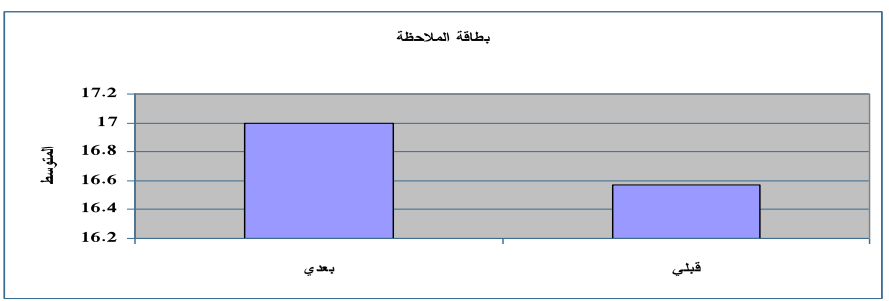

و الصورة التفصيلية للنتائج تتضح من الجدول رقم (11) التالي:

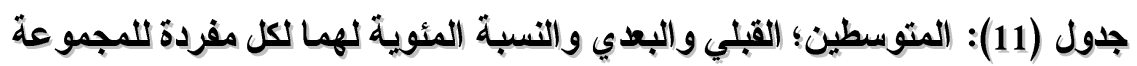
الضابطة

\begin{tabular}{|c|c|c|c|c|c|}
\hline النسبة المئوية & البعديط & المئوية لهبة & المتوسط القبلي & الارجة & البنود \\
\hline 66.67 & 2.00 & 66.67 & 2.00 & 3 & 1 \\
\hline 66.67 & 2.00 & 66.67 & 2.00 & 3 & 2 \\
\hline 45.33 & 1.36 & 45.33 & 1.36 & 3 & 3 \\
\hline 28.67 & 0.86 & 31.00 & 0.93 & 3 & 4 \\
\hline 47.67 & 1.43 & 40.33 & 1.21 & 3 & 5 \\
\hline 14.33 & 0.43 & 9.67 & 0.29 & 3 & 6 \\
\hline 31.00 & 0.93 & 28.67 & 0.86 & 3 & 7 \\
\hline 38.00 & 1.14 & 35.67 & 1.07 & 3 & 8 \\
\hline 21.33 & 0.64 & 16.67 & 0.50 & 3 & 9 \\
\hline 71.33 & 2.14 & 76.33 & 2.29 & 3 & 10 \\
\hline 4.67 & 0.14 & 7.00 & 0.21 & 3 & 11 \\
\hline 35.67 & 1.07 & 38.00 & 1.14 & 3 & 12 \\
\hline 45.33 & 1.36 & 45.33 & 1.36 & 3 & 13 \\
\hline 16.67 & 0.50 & 16.67 & 0.50 & 3 & 14 \\
\hline 19.00 & 0.57 & 19.00 & 0.57 & 3 & 15 \\
\hline 14.33 & 0.43 & 9.67 & 0.29 & 3 & 16 \\
\hline 35.42 & 17.00 & 34.52 & 16.57 & 48 & المجموع الكلي \\
\hline
\end{tabular}

وباستقر اء الجدول السابق يتضح أن:

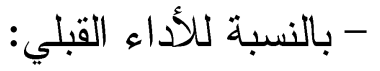
• حصل البند (10) "تعليم الكتابة مع بداية تعليم القراءة"، في بطاقة الملاحظة

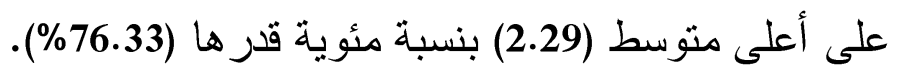
• حصل البند رقم (11) "تنمية مهارات الفهم عند تعلم أول وحدة لغوية تدل الفئل علي معني؛ كفهم أثز القيم الخلافية للأصوات فى تشكيل المعنى، وتمييز 
الصواب من الخطأ، و إعادة ترتيب الحروف لتكون كلمة لها معنى، و إعادة تزتيب كلمتي الجملة.." على أقل منتسط في القائمة (0.21) بنسبة مئوية قدر ها (7.00\%).

• تر اوحت متوسطات بقية بنود البطاقة بين متوسط (0.29) ونسبة مئوية قدر ها (9.67\%) إلى متوسط (2.00) ونسبة مئوية قدر ها (66.67\%). • كان متوسط المجموع الكلي للأداء (16.57) بنسبة مئوية قدر ها (34.52\%). - بالنسبة لنأداء البعدي: • حصل البند رقم (10) "تعليم الكتابة مع بداية تعليم القراءة"، في بطاقة الملاحظة على أعلى منوسط (2.14) بنسبة مئوية قدر ها (71.33\%). • حصل البند رقم (11) "تنمية مهار ات الفهم عند تعلم أول وحدة لغوية تدل علي معني؛ كفه أثز القيم الخلافية للأصوات فى تشكيل المعنى، وتمييز الصو اب من الخطأ، و إعادة ترتيب الحروف لتكون كلمة لها معنى، و إعادة تزتيب كلمتي الجملة.." على أقل منوسط في القائمة (0.14) بنسبة مئوية قدر ها (4.67\%). • تر اوحت متوسطات بقية بنود القائمة بين منوسط (0.43) ونسبة مئوية قدر ها (14.33\%) إلى متوسط (2.00) ونسبة مئوية قدر ها (66.67\%). • كان منوسط المجموع الكلي للأداء (17.00) بنسبة مئوية قدر ها (35.42\%). ويمكن تمثيل المتوسط القبلي و البعدي لكل مفردة، و المجموع الكلي لهما بيانياً في الثكلين (9)، (10) التاليين: شكل (9) يوضح المثوسطين؛ القبلي و البعد لكل مفردة في بطاقة الملاحظة 


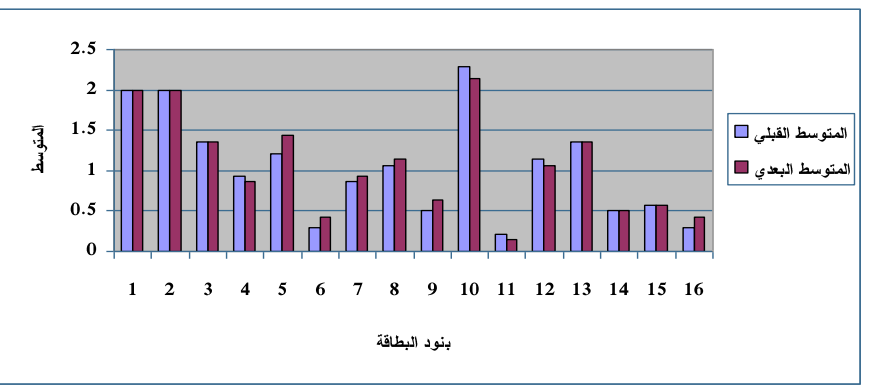

شكل (10) يوضح التمثيل البياني للمجموع الكلي للمتوسطين؛ القبلي و البعدي لبطاقة الملاحظة

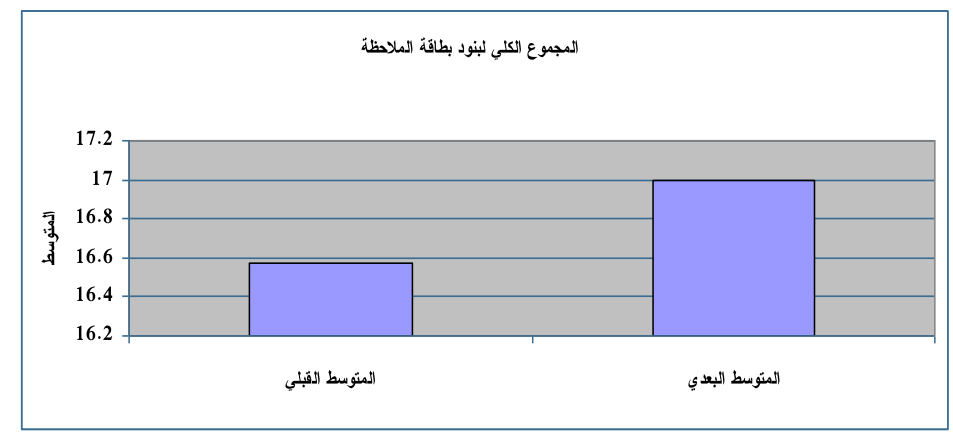

2- مناقشة النتائج وتفسبر ها:

أولاً: فيما يتعلق بوجية فود فرق دال بين تلاميذ المجمو عتين؛ الضابطة و التجريبية

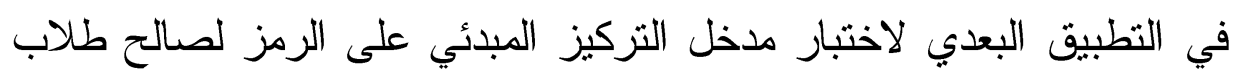

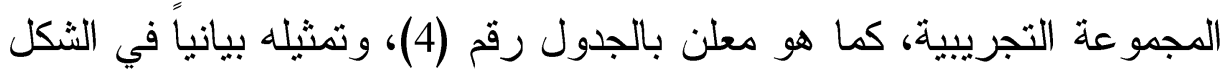
(1)، وكذا وجود فرق دال بين معلمي المجمو عة التجريبية في التطبيقين؛ القبلي البعدي لاختبار مدخل التركيز المبئي على الرمز لصالح التطبيق البعدي دئي

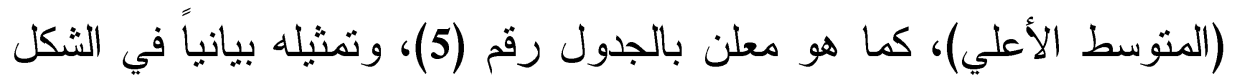

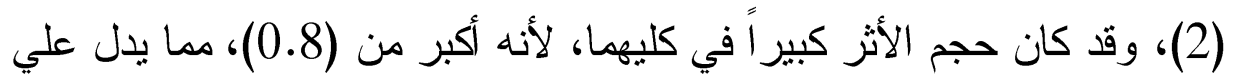
أن تأثير البرنامج التدريبي علي تتمية معلومات ومعارف مدخل التركيز

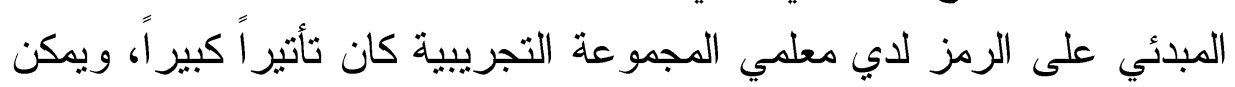

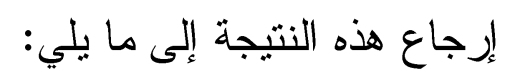


1- اكتساب المعلمين المتدربين للمعارف المتعلقة بتعليم القر اعة وفق مــدخل التركيز المبئي على الرمز، وذللك من خلال البرنامج التتريبي الذي استمر

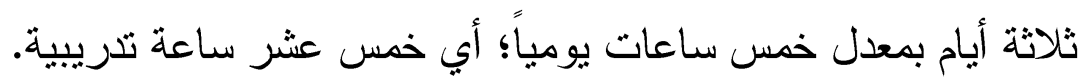

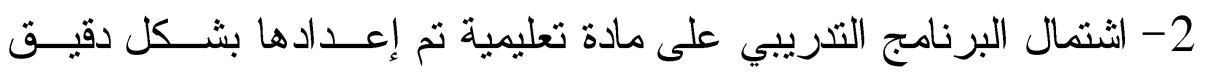

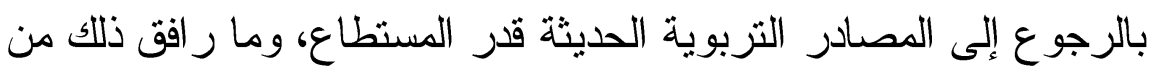
أنشطة متنو عة نم تطبيقها على المتذربين.

3- ربما بعود السبب في هذه النتيجة إلى ضعف إلمام المعلمين المتدربين بهذا

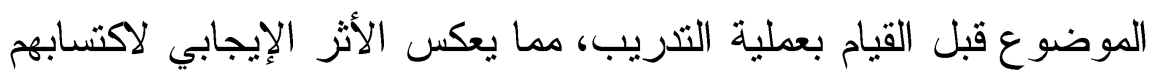
المعارف نتيجة عملية التكريب. 4- الأسلوب المشوق في عرض البرنامج التدريبي، وطر ائق التدريب المختلفة

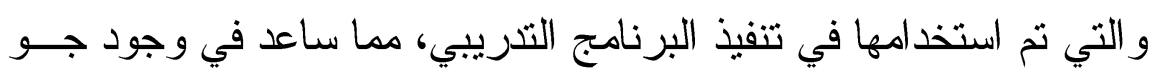
من التحفيز و التثويق للتعلم. 5- تطبيق أساليب تزيد من فاعلية البرنامج التـريبي كــالحو ار ، و المناقتـــة، وحل المشكلات، و التعلم الذاتي، و العصف الذهني، مما ساعد على إلىــام المعلمين المتدربين بالمعارف و المعلومات الخاصة بمدخل التركيز المبدئي

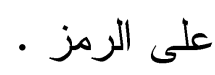
6- التلازم بين المعلومات النظريةو العملية في عرض البرنامج التنريبي ،مما ساعد المعلم المتدرب على استيعاب تلك المعلومات. ثانياً: فيما يتعلق بوجود فرق دال بين معلمي المجمو عتين؛ الضابطة و التجريبية

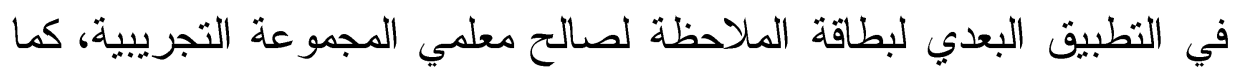

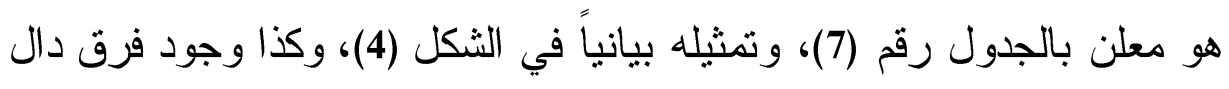

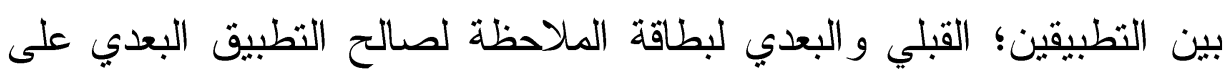
معلمي المجموعة التجريبية (المتوسط الأعلي) كما هو معلن بالجدول رقم doi : 10.12816/0001054 
(8)،وتثنيله بيانياً في الثكل (5)، وقد كان حجم الأثر في كليهما كبيراً، لأنه

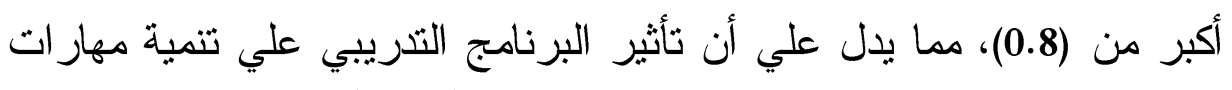

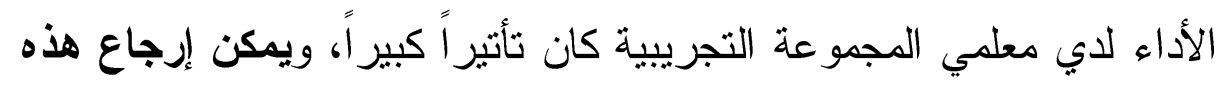
النتيجة إلىى:

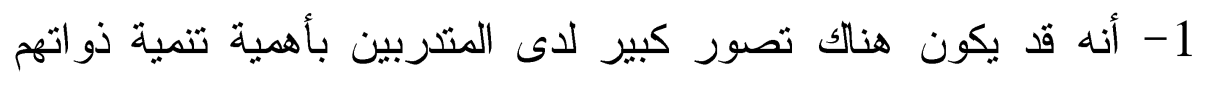

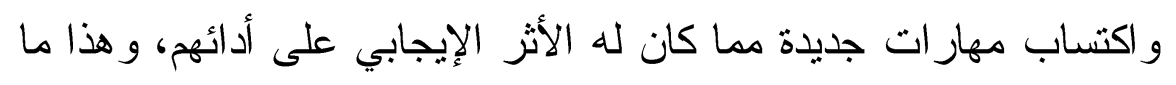

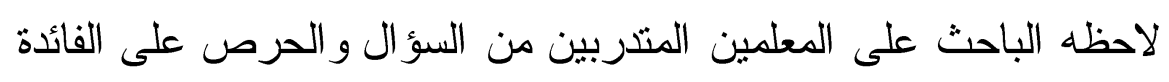

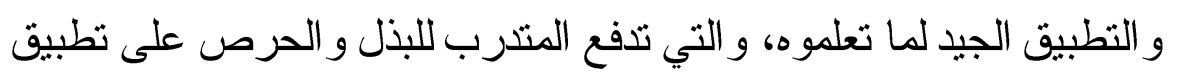
ما تعلمه في مو اقف جديدة، و اكتساب مهار ات فاعلة ومؤثرة في العملية التعليمية.

2- رغبة المعلمين في اكتساب مهارات جديدة، وتحسين الأداء في العملية

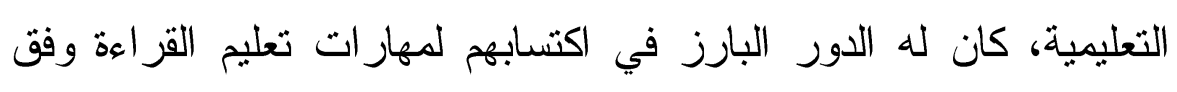

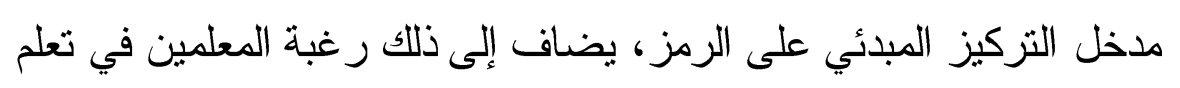

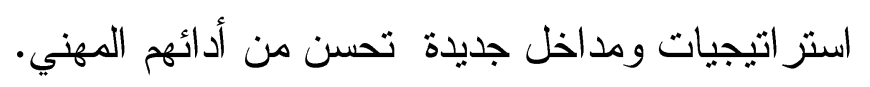

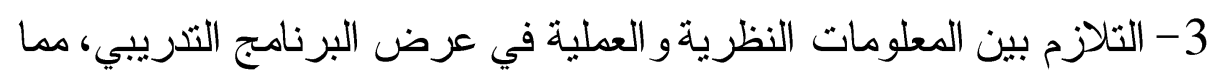

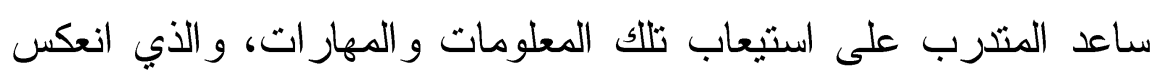
بدوره على أداء المعلم في تطبيقها.

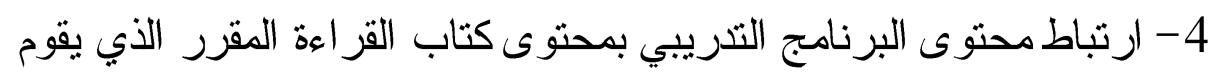

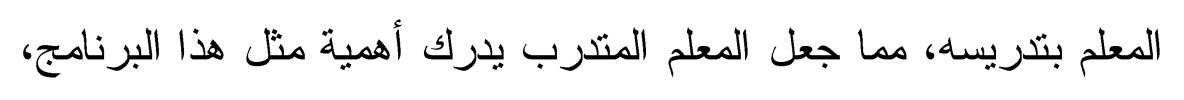

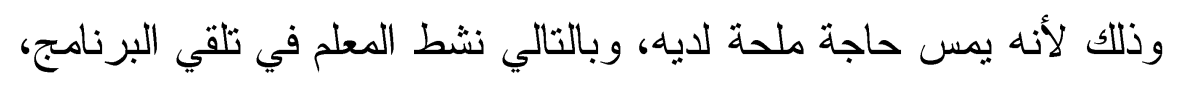
وتطبيق المهارات، و هذه هي أحد الأهداف التي يسعى إلى تحقيقها التدريب أثناء الخذمة. 5- المزج بين النظرية و التطبيق مما كان له أثر فاعل في اكتساب المعلمين المتربين مهارات تدريس مدخل النزكيز على الرمز .. 
6- إعطاء المتدربين الوقت الكافي للتعلم والتطبيق العملي لما تعلموه، وتزويدهم بالتغذية الراجعة، مما كان له أثز في تحسين الأداء و اكتساب إلهاب مهار ات تدريس مدخل التركيز على الرمز.

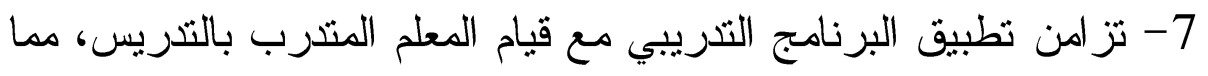

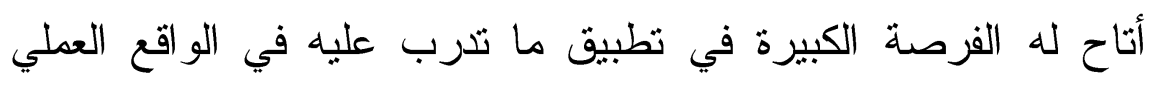

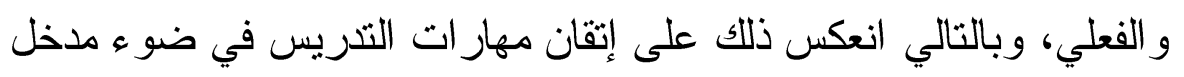
التزكيز على الرهز.

8- التفاعل الايجابي المتبادل بين المتدربين وبين المدرب، وتوفير قدر من المسئولية الفردية في التعلم و التدريب، مها كان له أثز بارز في بذل كل

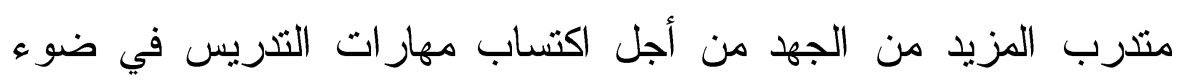

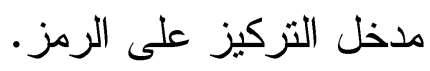
9- اعتماد البرنامج التثريبي على بعض الاستر اتيجيات، و التي كان لها دور في جعل المتدرب هو الأساس في عملية التدريب، مما كان لذلك التعلم

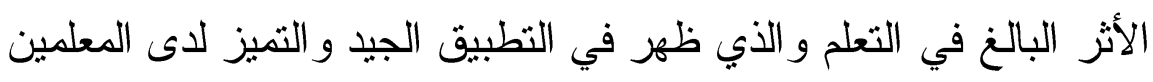

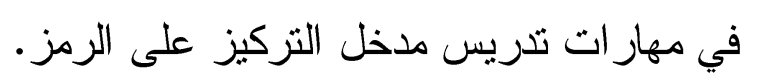

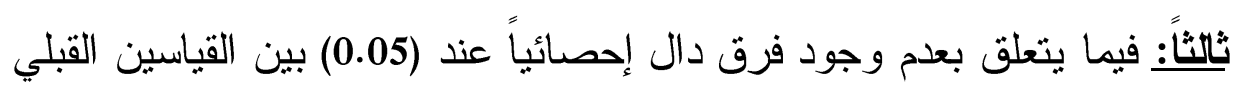
و البعدي لاختبار مدخل التركيز المبدئي على الرمز للمجموعة الضابطة، كما ديا

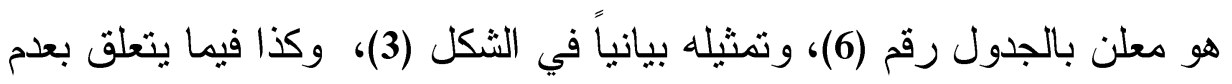

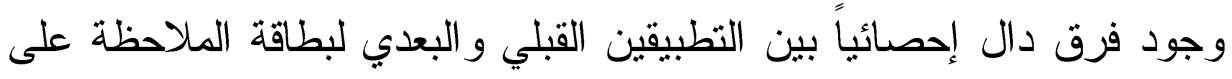
المجموعة الضابطة، كما هو معلن بالجدول رقم (10)، وتمثيله بيانياً في الثكل

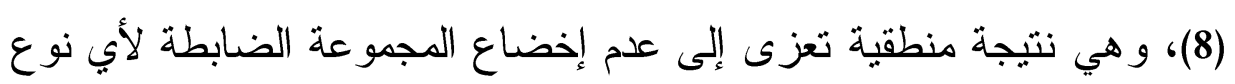

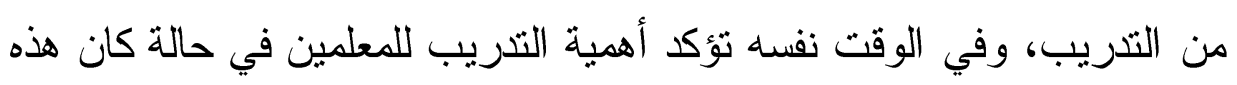


التشريب حاجة ملحة لهم، كما في حالة تدريبهم على مدخل التركيز المبدئي على الرمز الذي تستهدفه الدر اسة الحالية. رابعاً: فيما يتعلق بالمتوسطين؛ القبلي و البعدي و النسبة المئوية لهما، لكل مفردة

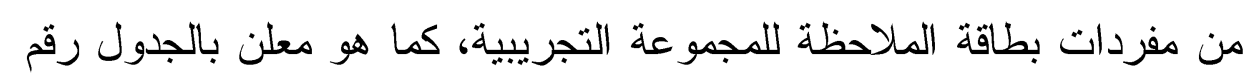

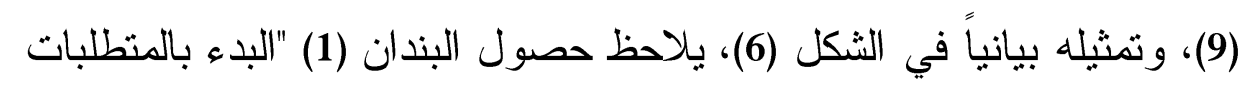

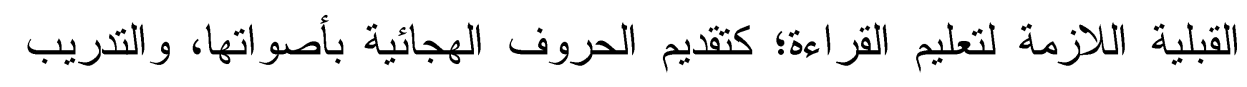

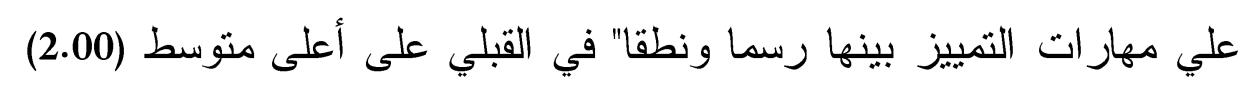

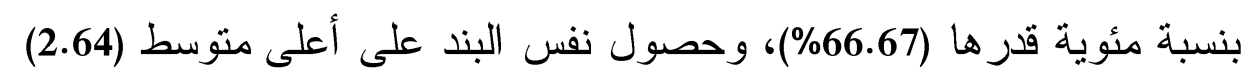

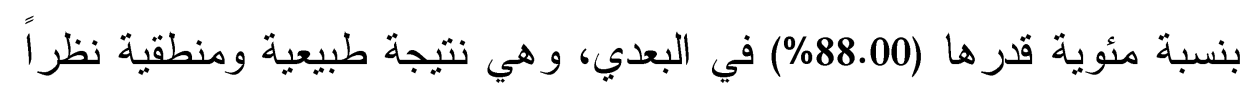

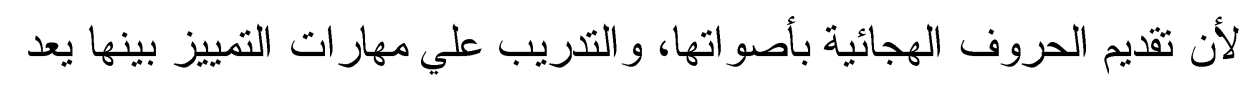
البداية في تعليم القراءة وفق إجراءات الطريقة الصوتية التي تعتمد كطريقة

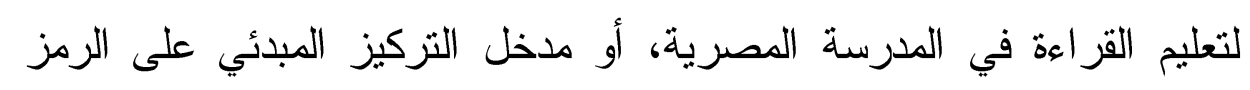
الذي تعتمده الدر اسة الحالية. - فيما يتعلق بحصول البند رقم (11) "تتمية مهار ات الفهم عند تعلم أول وحدة لفئ

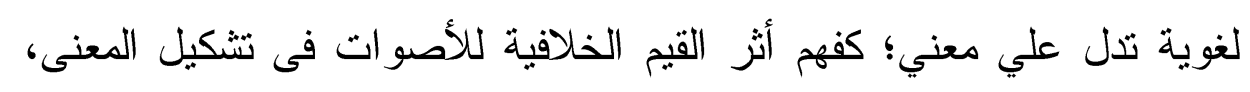

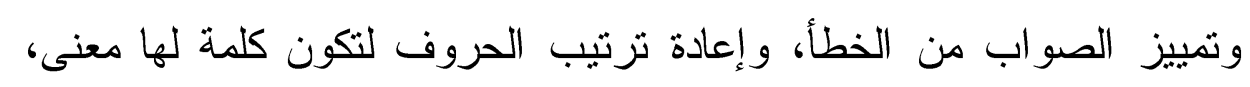
و إعادة ترتيب كلمتي الجملة.." على أقل متوسط في القائمة (0.14) بنسبة مئوية قدر ها (4.67\%) في القبلي، و هي أيضاً نتيجة طبيعية ومنطقية كذلك، فالمعلمون

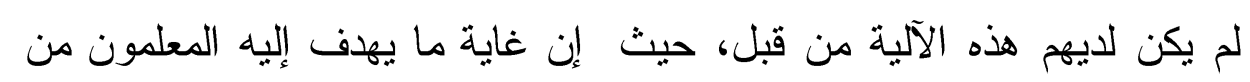

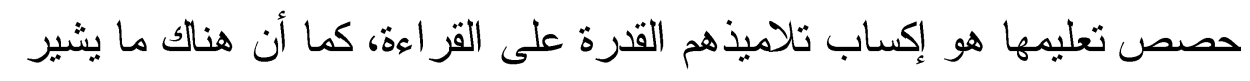
إلى جهل معظم المعلمين بالنماذج التي تفسر كيفية حدوث الاستيعاب،

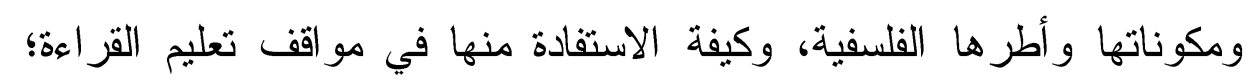
لتقديم أثنكال العون الفني للتناميذ لبلوغ مستويات منقدمة للاستيعاب القرائي

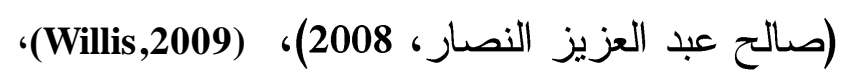


- وفيما يتعلق بحصول البند رقم (9) "تعزيز المهار ات التى سبق در استها" على

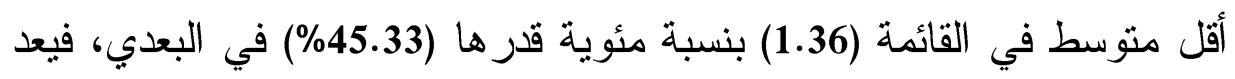

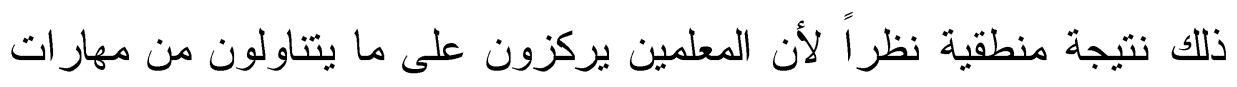

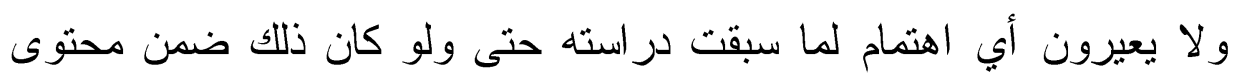

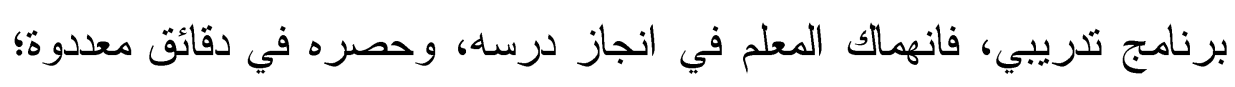

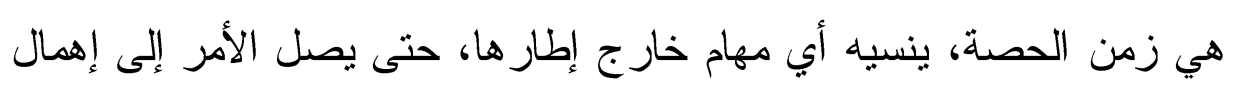

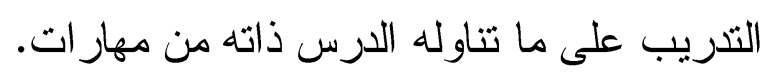

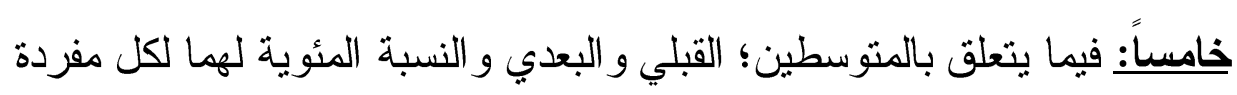
للمجموعة الضابطة، كما هو معلن بالجدول رقم (11)، وتمثيله بيانياً في الشكل (9)، يلاحظ حصول البند (10) "تعليم الكتابة مع بداية تعليم القر اءة"، في بطاقة بلهي

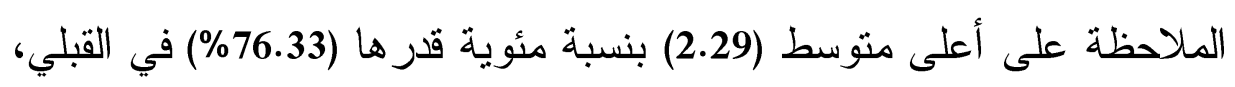
وحصول نفس البند على أعلى متوسط (2.14) بنسبة مئوية قررها (71.33\%)

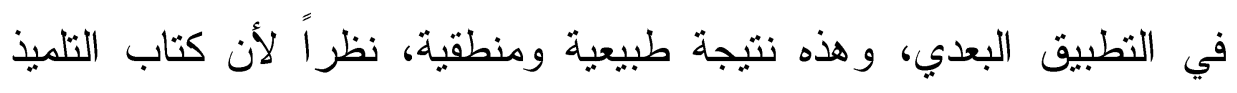

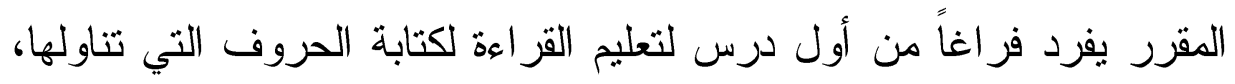

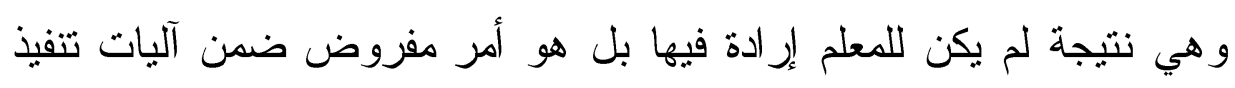
الاروس المرسومة له.

- فيما يتعلق بحصول البند رقم (11) "تنمية مهار ات الفهم عند تعلم أول وحدة

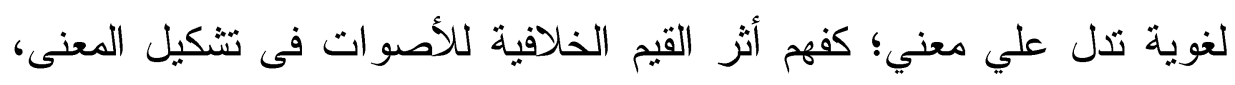

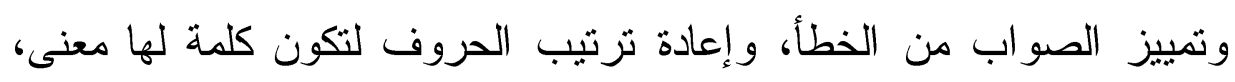
و إعادة نرتيب كلمتي الجملة.." على أقل متوسط في القائمة (0.21) بنسبة مئوية قدرها (7.00\%) في القبلي، وحصول البند نفسه على أقل متوسط في القائمة (0.14) بنسبة مئوية قدر ها (4.67\%) في التطبيق البعدي، و هذه نتيجة منطقية تؤكدها ما سبق ذكره بالنسبة للمجموعة التجريبية فيما يتعلق بهذا البند على فئى doi : 10.12816/0001054 
مجلة الدراسات التريوية و الاسنية ـ كلية التربية ـ جامعة دمنهور ـ المجلد الخامس العد (1) لسنة 2013

وجه الخصوص، بما يؤكد اهتمام المعلمين بالتركيز على القراعة الميكانيكية

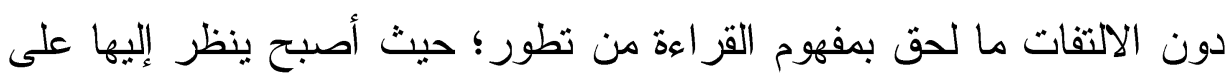

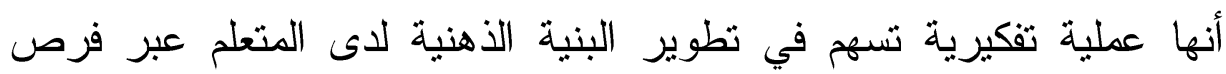

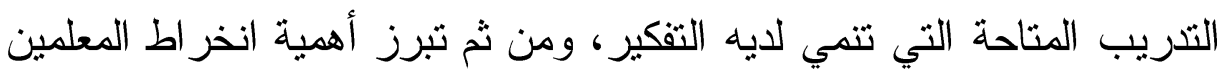

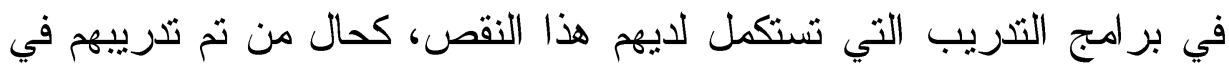
البرنامج الذي استهدفته الدر اسة الحالية. 


\section{ثُلثاً: التوصبات و المقترحات:}

1- مر اعاة إعداد محتوى كتاب القراءة وفق مقتضيات مدخل التزكيز على

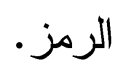

2- الإفادة من بطاقة الملاحظة في تقويم أداء معلمي القراءة للصف الأول

$$
\text { الابتدائي. }
$$

3- تنفيذ البرنامج المُقترح على معلمي القراءة للصف الأول، و الاستفادة منه

$$
\text { لتطوير آدائهم. }
$$

4- تقديم الحوافز المادية و المعنوية لحضور الدور العهات التدريبية انطلاقاً من دور ها الكبير في تطوير تدريس اللغة العربية.

5- الاهنمام بجانبي المعرفة و الأداء عند تقويم أداء المعلمين السنوي.

في ضوء ما أسفرت عنه الاراسة من نتائج؛ توصي بما يلي:

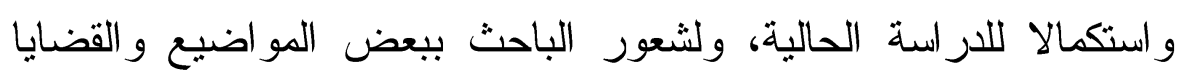

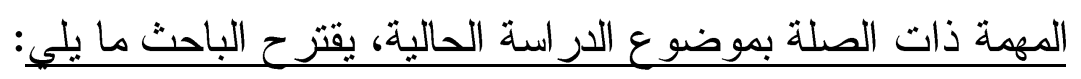
1 - إجر اء در اسة مماثلة على عينات أوسع.

2- تقويم كتاب اللغة العربية للصف الأول في ضوء هدخل مدل التزكيز المبدئي

$$
\text { على الرمز. }
$$

3- رأي القائين على تعليم اللغة العربية للصف الأول الابتدائي في تعليم

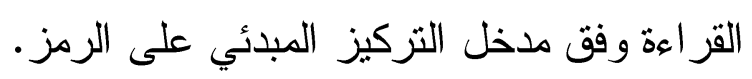

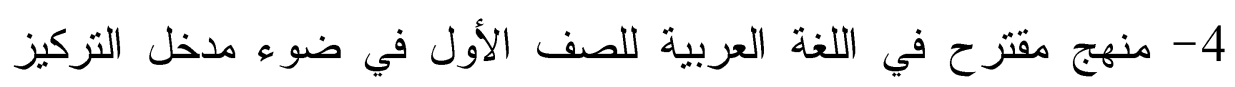

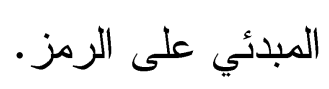




\section{المراجي:}

أولاً: المراجي العربية:

1 - أحمد المهاي عبدالحليم (1999): التحديات التربوية للأمة العربية،

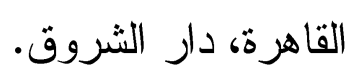

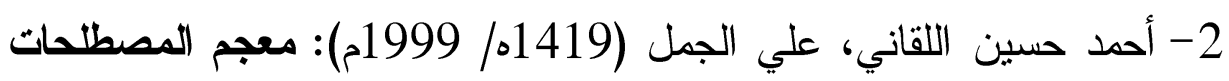
التربوية المعرفة في المناهج وطرق التدريس، القـاهرة، عـالم المعات

الكتب.

3- الحسن الجعفر خليفة (1992): "برنامج مقترح لإعداد مطلم اللغة العربية

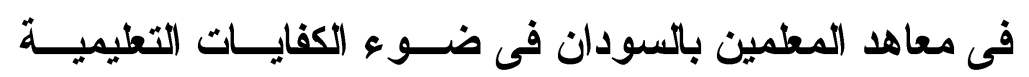

الأساسية"، رسالة ككتور اه غير منشورة، كلية التربية، جامعــة فئسية

$$
\text { الأز هر، ص85. - الاسية"، رساسلة }
$$

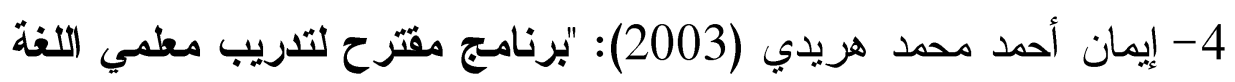

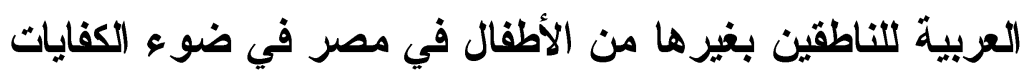

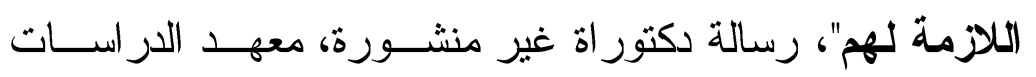

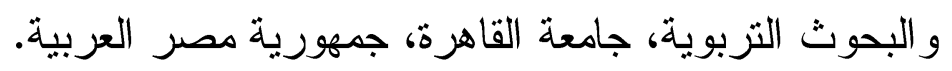

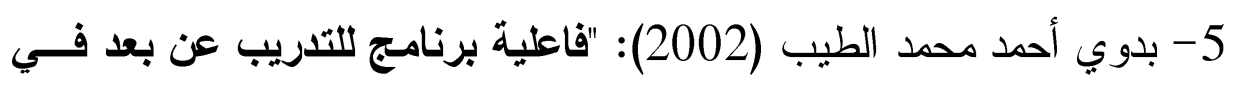

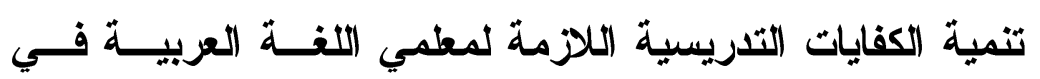

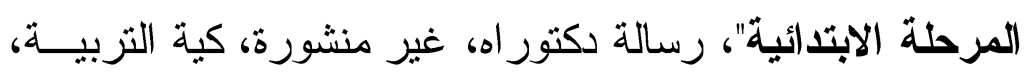

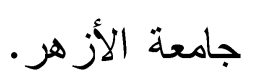

6- بدوي أحمد محمد الطيب (2010): "تنمية بعض المهارات اللغوية اللازمة

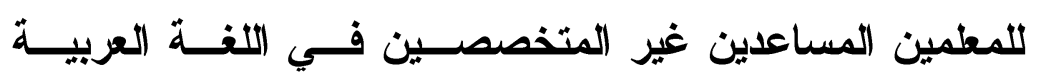

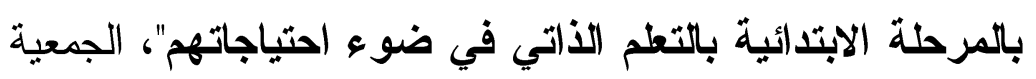

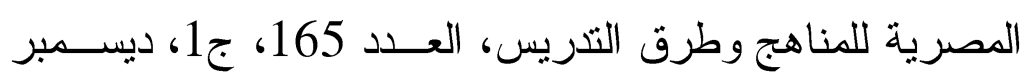
.2010 
7- جمال سلامة (2001): "فاعلية التدريب الميداني في تنمية المهــارا ت التمات

التدريسية لاى الطلاب المعلمين"، عالم التربية، المجموعـــة 2 ،

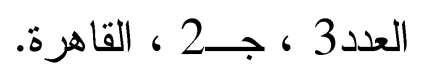

8- سناء طيبي (2006): "إجراءات التخخل المبكر للوقاية من الفشل في

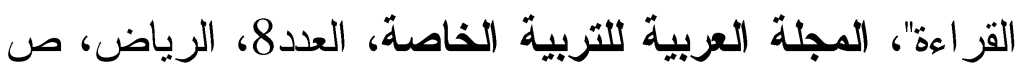

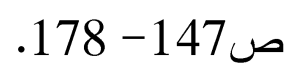

9- عبد الحميد زهري سعد عطا الله (2006): "فاعلية برنامج تدريبي لتنمية كفاءات التدريس وتحقيق متطلبات الجودة للى مطظمــي اللغــة

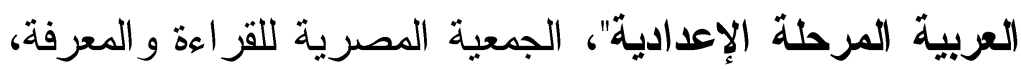

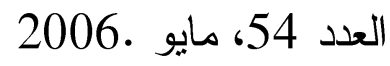

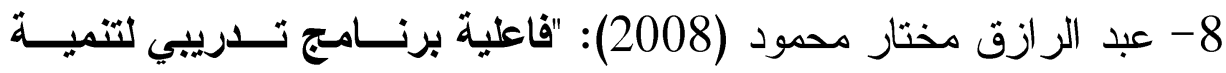

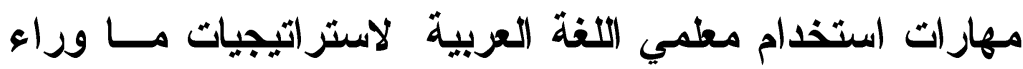

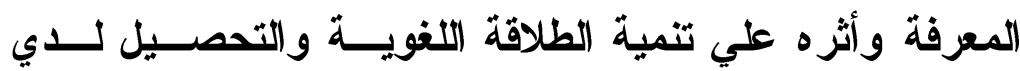
طلابهم"، الجمعية المصرية للمناهج وطرق التدريس، العدد3ية،

$$
\text { أكتوبر } 2008 .
$$

10- عبدالرحمن الصغير (1996): "برنامج تدريبي مقترح لتنمية الكفايـات

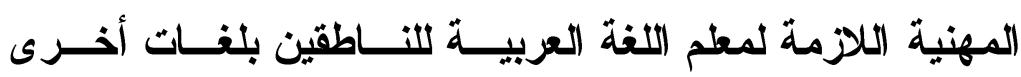

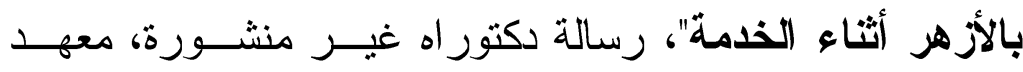

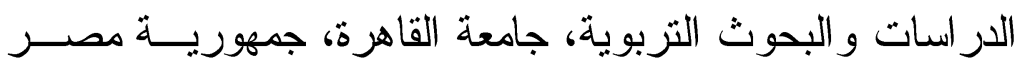

$$
\text { العربية. }
$$

11- علي سلام، فاروق خليفة (2012): أساسيات تعليم القراعة والكتابــة،

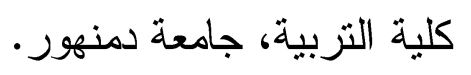


12- فاروق خليفة أبوزيد (1993): "التفاعل بين بعض مداخل تعليم القراعة

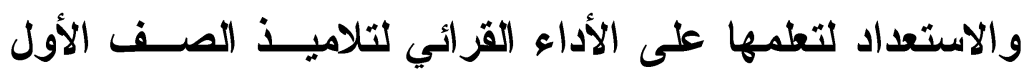

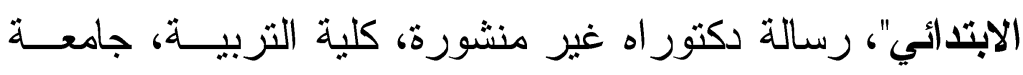

$$
\text { الإسكندرية. }
$$

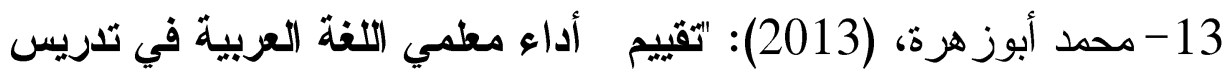

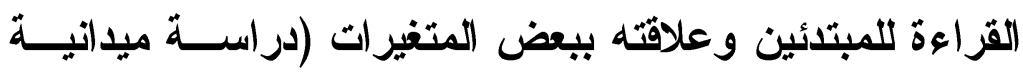

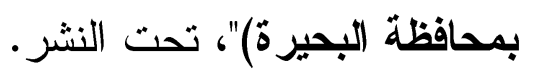

14-مباركة صالح الأكرف (1990): "تظوير برامج تدريب معلمة الفصــل فئل

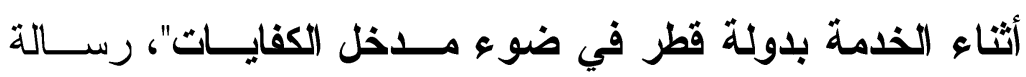
لكتور اة غير منشورة، كلية التزبية، جامعة عين شمس، جمهورية

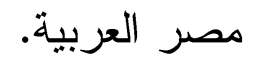

15- محمد إبر اهيم الخطيب (1990): "فاعلية استخدام برنامج تدريبي مقترح

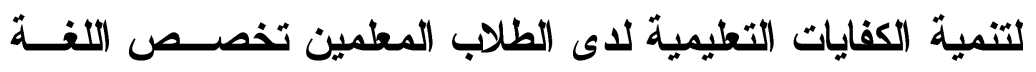

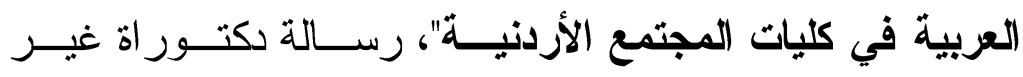

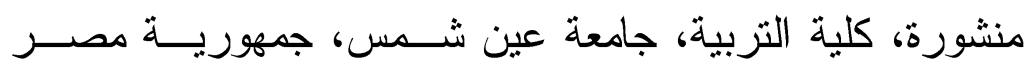
العربية. 16- محمد أحمد أحمد عيسي (2009): "فاعلية برنامج تدريبي مقترح فــي تنمية مهارات تلريس البلاغة لاى الطلاب مطمي اللغة العربية

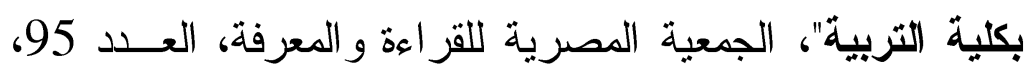

$$
\text { سبتمبر } 2009 .
$$

17- محمد السيد سعيد (2005): "تنمية مهارات تدريس الهجاء لاى الطلاب

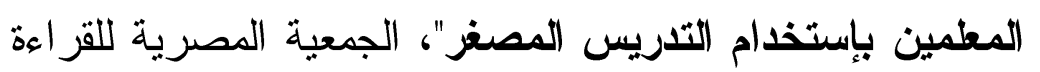
و المعرفة، العدد 47، سبتمر .2005 بلنين 


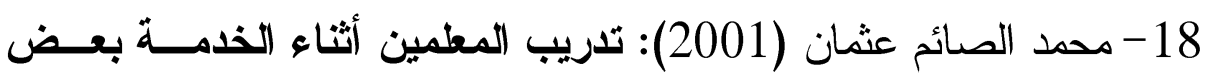
التجارب المعاصرة، ط1، بيشة، مكتبة الخبتي الثقافية.

19- محمد رجب فضل الله (1998): واقع تلدريب معلمــي اللغــة العربيــة بالمراحل التعليمية المختلفة أثناء الخدمة (ومقترحات لتطويره)، الجمعية المصرية للمناهج وطرق التدريس، مجلة در اسات فـي التئي المناهج وطرق التدريس، العدد (46)، يوليو 1998، كلية التزبية، جامعة عين شمس، 149-186.

20- محمد رفعت حسنين (2004): فعالية برنامج تدريبي لتنمية الكفايـات

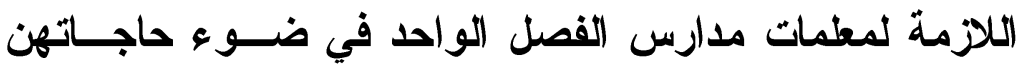

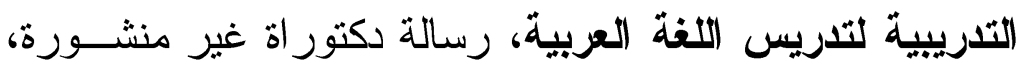

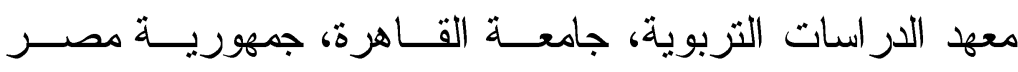

$$
\text { العربية. }
$$

21- محمد سالم الهرمة (1996): "برنامج مقترح لتنمية بعـض الكفايـات

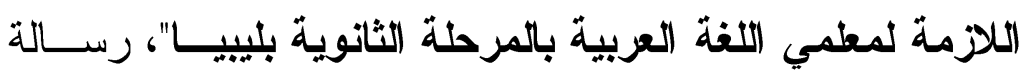

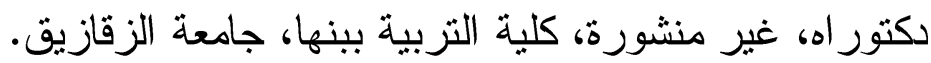
22- محمد عبود الحراحشة (2005): "فاعية البرامج التدريبية للمطمين في

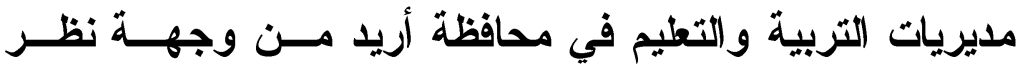

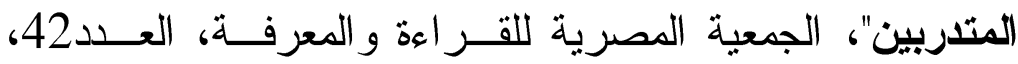

$$
\text { فبر اير .2005 }
$$

23- محمد عزت عبد الموجود (1997): إعداد وتلدريب المعلم في الــوطن

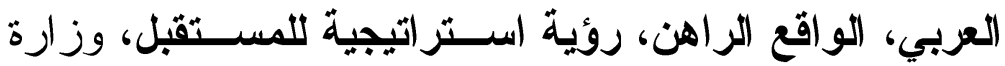

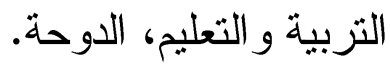


24- محمد لطفي جاد (2007): "صور مقترح لبرنامج تدريبي لمعلمي اللغة

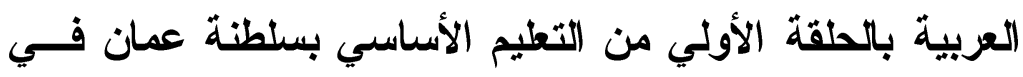

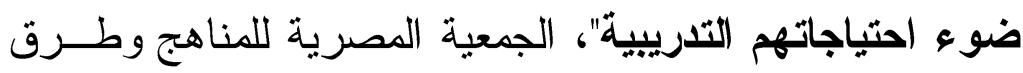

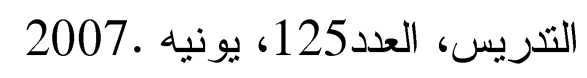

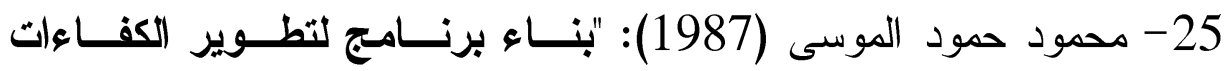
التتريسية لمعلم اللغة العربية في المرحلة المتوسطة في المملكة

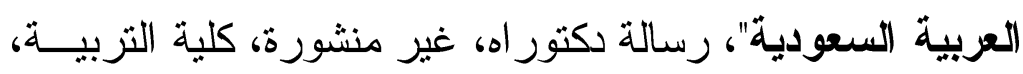
جامعة عين شمس.

26- محمود كامل الناقة (1997): تعليم اللغة العربية و التحديات الثقافية التي

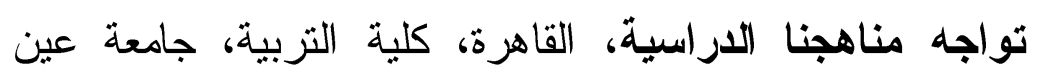
شمس.

27- مريم محمد عايد (2005): "برنامج مفترح لتدريب معمات اللغة العربية

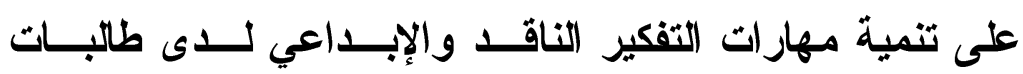

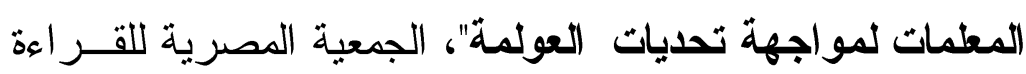

$$
\text { و المعرفة، العدد 48، اكتوبر .2005 }
$$

28- مصطفى محمد كامل (2004): "التظيم الأتي للتعلم والنمو المهني للمعلم"، المؤتمر العلمي16 (تكوين المعلم)، مجلد2، القاهرة،

$$
\text { الجمعية المصرية للمناهج وطرق التدريس. }
$$

29- نادية العطاب (2004): "فاعلية برنامج تعليمي للتربية العملية في أداء ولئ الطلب المدرس للمهارات التدريسية واتجاهه نحو مهنة التدريس"، المؤتمر العلمي السادس عشر للجمعية المصرية للمناهج وطرق التذريس، المجلد الثاني ، القاهرة. 
30- هدى محمد إمام صالح (2008): "برنامج مقترح لتدريب معلمي الكبار

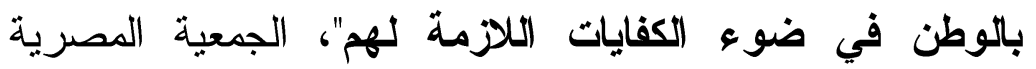

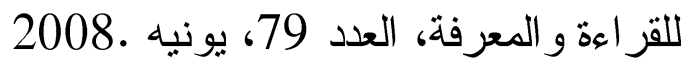

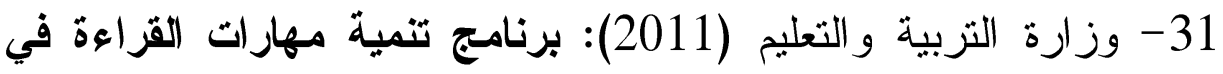

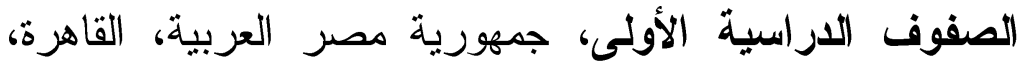
أكتوبر 2011.

http://www.giloegypt.org/egrp

32- وفاء العويضي، (1422/ 20012): "أثر برنامج تدريبي قائم على مطالب تعليم المقرر ات الدر اسية في كفاءة الطالبات معلمات اللغة العربية"، رسالة دكتوراة غير منشورة، كلية التربية، وكالة الرئاسة لكليات البنات، جدة. ثاتباً: المر اجِيع الأجنبية:

1-Barr, Repecca (1991); “Toward a Balanced pe rspective on Beginning

Reading" in journal of Educational Research, May.

Vol. 20, No. 4.

2-Beech, John; Pedly, Helen (1994); Training letter to sound Connections;

The efficacy of tracing current psychology, summer,

(3)2, 153- 12.

3-Corcoran, Thomas B (1995); Helping teacher well: Transforming

Professional Development, Retrieved: 5/ 10/ 2006 from the World Wide.

4-Web: http//www.ed.gov/pubs/CPRE/index.html.

5-Correia, Marlene p.; Mchenry, Jana M (2002); The Mentors Handbook: Practical Suggestions for Collaborative Reflection and Analysis, Norwood, Massachusetts; ChristopherGordon Publisher, Inc.

6-Clearinghouse on Teaching and Teacher Education (1995);

Reconceptualizing Professional Development, Washington D C: ERIC ED 383695. 
7-Dilworth, Mary E; Imig, David G (1995); Professional Teacher Development and the Reform Agenda, ERIC Digest, ED 383694.

8-Drektrah, Mary Eller; Chang, Bettram(1997); Instuctional strategies used by general educators and Teachers of students with learning disabilities, remedial And special educations, May/ Jum (8)3, 174- 8.

9-Edgetron, Mary Allen (2000); the effectiveness of staff Development program, The university of north cading at Chapel Hill. (non published).

10-Edwards, Jerridenise (2000); The relationship of Phonological, visual, and temporal processing to Reading disabilities university of Alabama at Birmingham (non published).

11-Ehri, L.C., Nunes, S.N., Stahl, S.A. \& Willows D.M., (2001); Systematic phonics instruction helps students learn to read: Evidence from the National Reading Panel's meta analysis. Review of Educational Research, 71, 393-447.

12-Elbehiri, G., \& Everatt, J. (2007); Literacy ability and phonological processing skills amongst dyslexi and non- dyslexi speakers of Arabic. Reading and Writting, 20, 273-294.

13-Fang, Z., (2010): Developing writing discourse knowledge in whole language and code emphasis classrooms, British journal of Educational psychology, 70 (3): 317- 335.

14-Garcia Gorgia. Ernst \& P. David, Pearson (1991); "Modifying Reading Instruction to Maximize its Effectiveness for all students, in "Michael S. Knapp, Patrick M. shields; better schooling for that children of poverty, New York; McCutchan publishing corporation, May.

15-Hooks, Linda; Peach, Walter: Effectiveness of phonics for students with learning disabilities. Journal of Instructional Psychology, Vol 20(3), Sep 1993, 243-245.

16-Levin, I., Shatil- Carmon, S. \& Asif-Rave, O. (2005): Learning of letter names and sounds and their

17-contribution to word recognition. Journal of Experimantal Child Psychology, 93, 139-165.

18-Levin, I. \& Saiegh- Haddad, E., Hende, N., \& Ziv, M. (2008); early Literacy in Arabic: An intervetion with Israeli Palestinian Kindergarteners. Applied Psycholinguistics, 29, 413-436.

19-Perkins June Helen (1999); Effective teaching methods Which enhance the literacy skills of fourth grade African 
American students as identified by elementary School teachers, Oklahoma state university (non published)

20-Shankweiler, Donaled (1991); "Starting on the Right foot" in American Education Research journal, May.

21-Shankweiler, D. \& Fowler, A.E. (2004). Questions people ask about the role of phonological processes in learning to read. Reading and Writting, 17, 483-515.

22-Share, D. (1995). Phonological recording and self-teaching: Sine qua non of reading acquisition. Cognition, 55, 151-218.

23-Smith Sandra Hargrove (1998); The effect of auhole Language method of instruction and an integrated Phonics method of instruction on the reading Achieverment of inner- city, preschool pupils the grade Washington university (non published).

24-National conference of state Legislatures (2002): The forum for Americas Ideas Policy Options for Improved Professional Development: A Road Map for Policymakers, U.S.A, NSDC.

25-National Reading Panel(2000). Report of the National Reading Panel teaching children to read; An evidence-based assessment of the scientific research literature on reading and its implications for reading instruction. Washington, Dc: National Institute of Child Health and Human Development.

26-Treiman, R., \& Rodriguez, K. (1999); Young children use letter names in learning to read words. Psychological Science, 10, 334-338.

27-Wyse, D. (2000): 'Phonics; The whole story? A critical review of empirical evidence, Educational. Studies, 26(3), 35544. 